PICO-SATELLITE INTEGRATED SYSTEM LEVEL TEST PROGRAM

\author{
A Thesis \\ presented to \\ the Faculty of California Polytechnic State University, \\ San Luis Obispo
}

\author{
In Partial Fulfillment \\ of the Requirements for the Degree \\ Master of Science in Aerospace Engineering
}

by

Marcus A. Ruddy

February 13, 2012 
(C) 2012

Marcus A. Ruddy

ALL RIGHTS RESERVED 


\section{COMMITTEE MEMBERSHIP}

TITLE:

AUTHOR:

COMMITTEE CHAIR:

COMMITTEE MEMBER:

COMMITTEE MEMBER:

COMMITTEE MEMBER:
Pico-Satellite Integrated System Level Test Program

Marcus A. Ruddy

February 13, 2012
Dr. Dianne DeTurris, Professor

Dr. Jordi Puig-Suari, Professor

Dr. Kurt Colvin, Professor 


\title{
ABSTRACT \\ Pico-Satellite Integrated System Level Test Program
}

\author{
Marcus A. Ruddy
}

Testing is an integral part of a satellite's development, requirements verification and risk mitigation efforts. A robust test program serves to verify construction, integration and assembly workmanship, ensures component, subsystem and system level functionality and reduces risk of mission or capability loss on orbit.

The objective of this thesis was to develop a detailed test program for pico-satellites with a focus on the Cal Poly CubeSat architecture. The test program established a testing baseline from which other programs or users could tailor to meet their needs. Inclusive of the test program was a detailed decomposition of discrete and derived test requirements compiled from the CubeSat and Launch Vehicle communities, military guidelines, and industry standards. The test requirements were integrated into a methodical, efficient and risk adverse test flow for verification.

Keywords: Pico-satellite, CubeSat, Satellites, Testing, Test Phases, Test Program, Requirements, MIL-STD, Risk Management, Systems Engineering 


\section{ACKNOWLEDGMENTS}

I would like to acknowledge and express my appreciation for the support I received on this project. Specifically, I want to thank:

- Dr. Dianne DeTurris of the Cal Poly Aerospace Engineering Department for her infinite patience and guidance as my advisor.

- Mike Bennett of Lockheed Martin for his technical direction.

- Dr. Eric Mehiel of the Cal Poly Aerospace Engineering Department for participating as a committee member and accepting an advisor role when the thesis topic drastically changed.

- Dr. Jordi Puig-Suari of the Cal Poly Aerospace Engineering Department and Dr. Kurt Colvin of the Cal Poly Industrial \& Manufacturing Engineering Department for participating as committee members.

- Roland Coehlo and Austin Williams from the Cal Poly PolySat Laboratory for their counsel on the PolySat architecture and development process.

- CubeSat community for paving a path to space and inspiring this thesis. 


\section{TABLE OF CONTENTS}

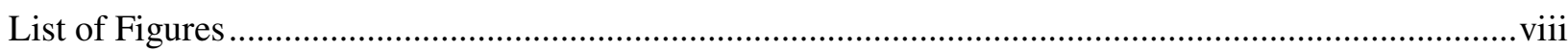

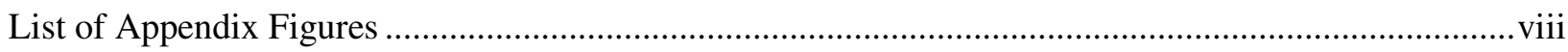

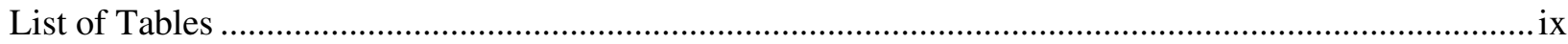

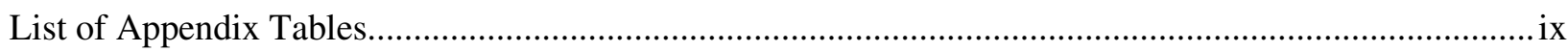

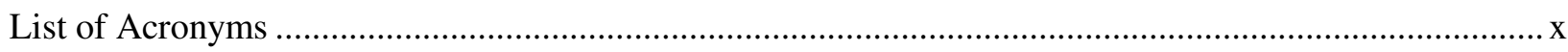

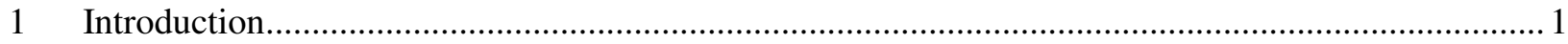

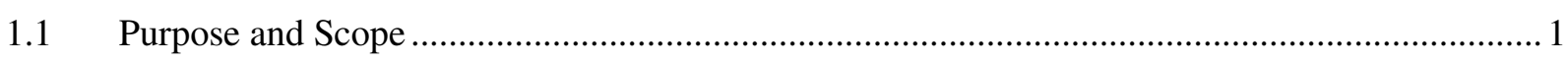

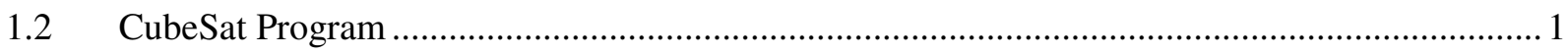

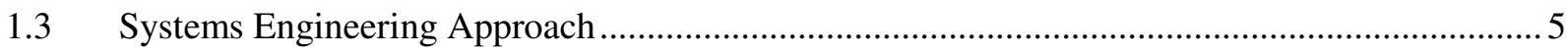

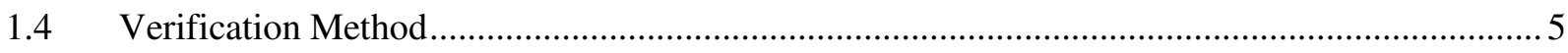

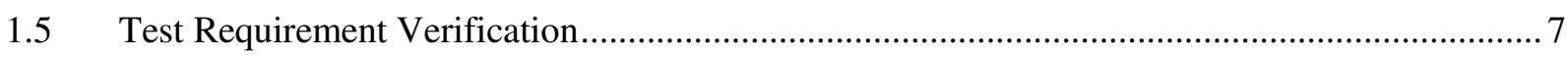

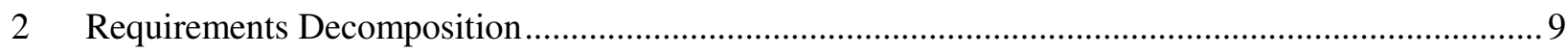

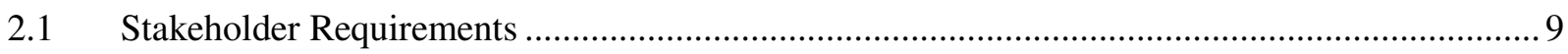

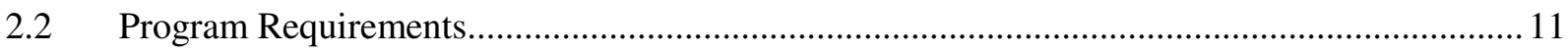

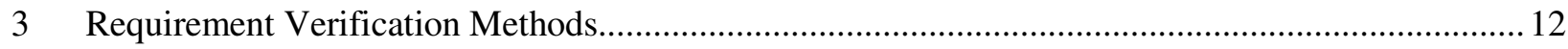

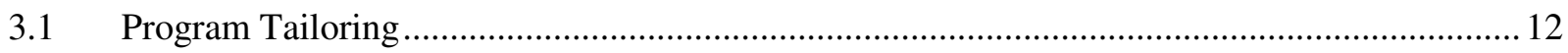

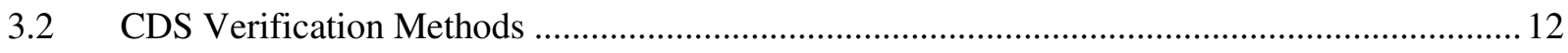

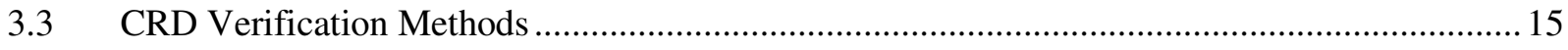

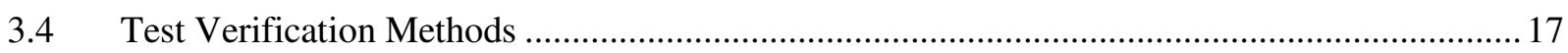

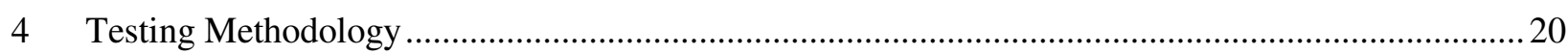

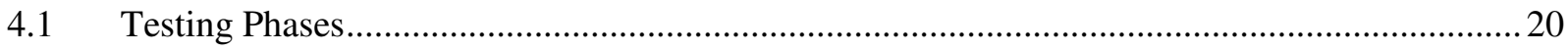

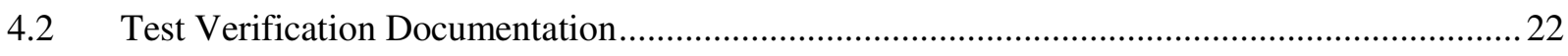

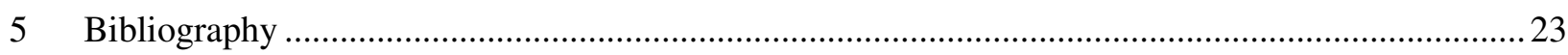

APPENDIX A: Pico-Satellite System Level Test Requirements Document .........................................26

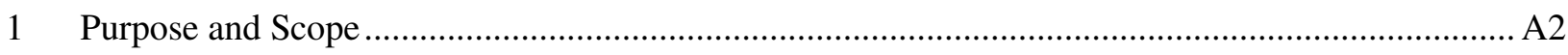

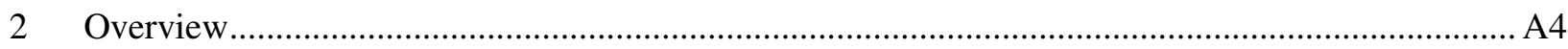

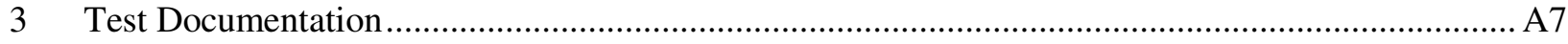

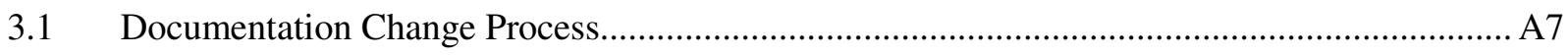

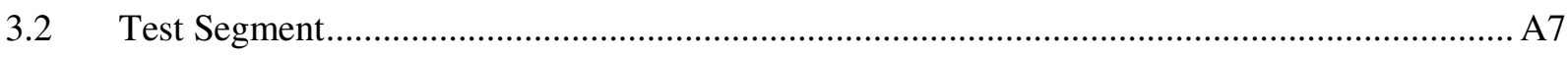

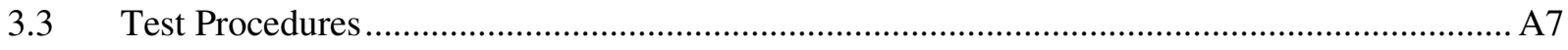

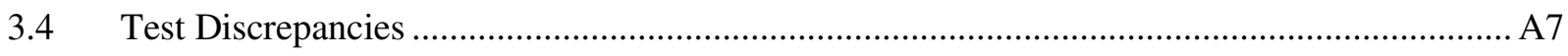

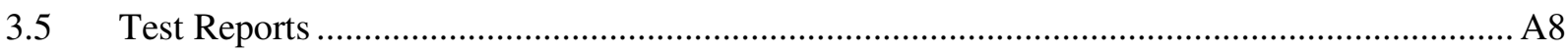

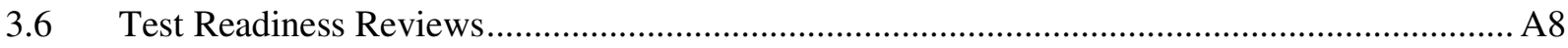

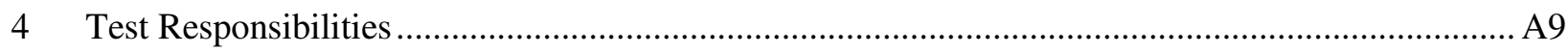

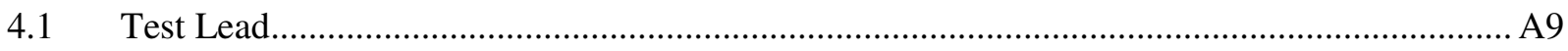

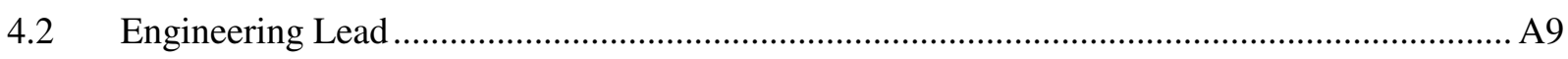

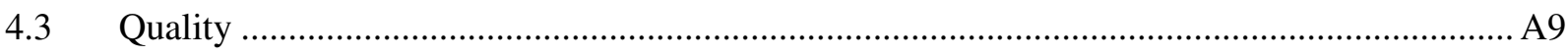

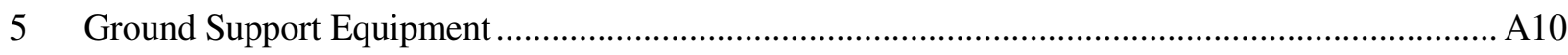

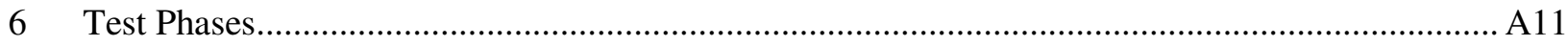

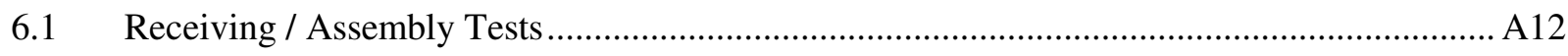

6.2 Preliminary Integrated System Test (PIST) ................................................................. A13

6.3 Electromagnetic Interference / Compatibility Test (EMI/EMC) .......................................... A14 


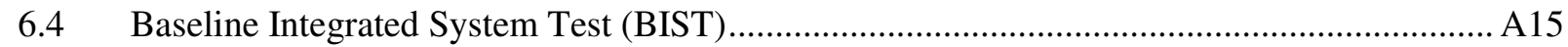

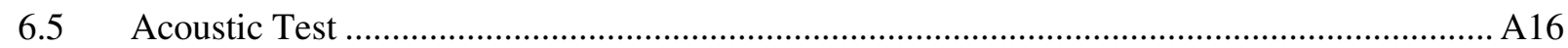

6.6 Thermal Vacuum Test (TVAC) …........................................................................... A17

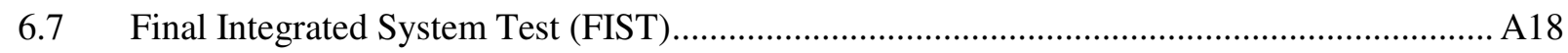

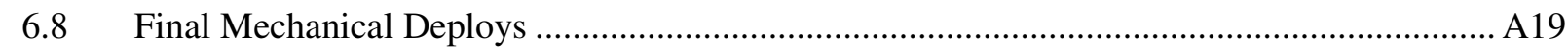

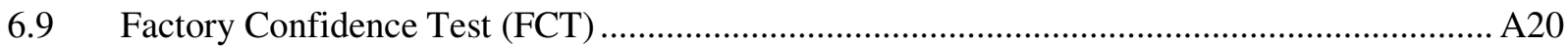

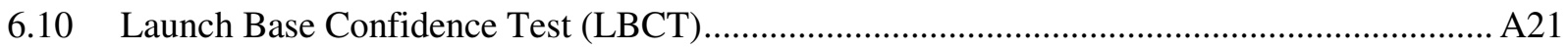

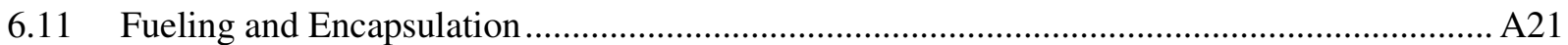

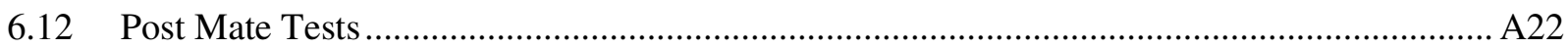

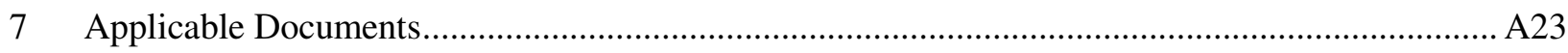

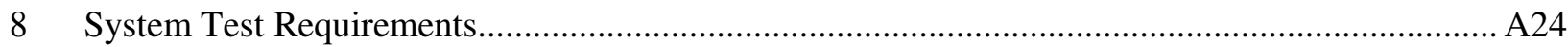

8.1 Attitude Control Subsystem (ACS) Test Requirements..................................................... A28

8.2 Command \& Data Handling Subsystem (C\&DH) Test Requirements .................................. A41

8.3 Communication (Comm) Subsystem Test Requirements .................................................. A52

8.4 Electrical Power Distribution Subsystem (EPDS) Test Requirements .................................. A61

8.5 Payload Subsystem Test Requirements ............................................................................ A74

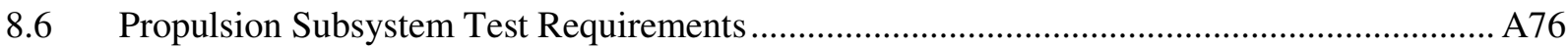

8.7 Structural \& Thermal Subsystem Test Requirements ........................................................... A77

9 Requirement Verification Documentation .................................................................................. A84 


\section{List of Figures}

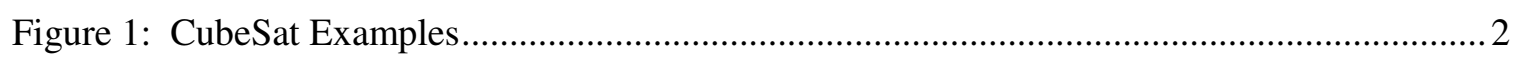

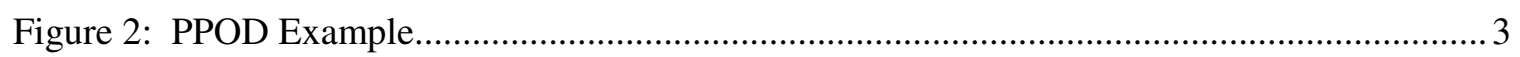

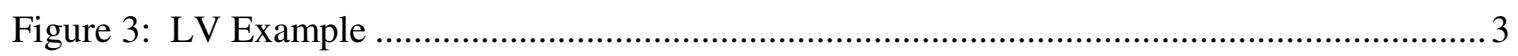

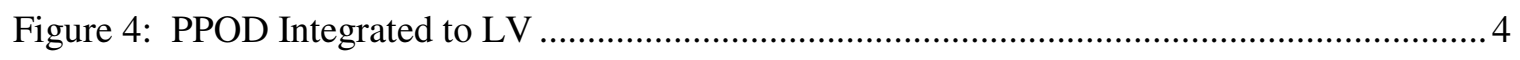

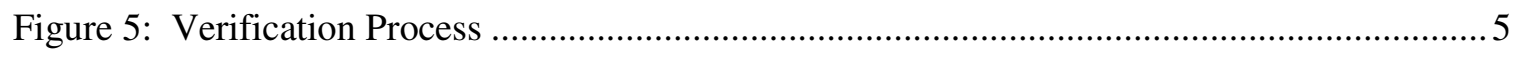

Figure 6: Requirement Decomposition Example .............................................................. 10

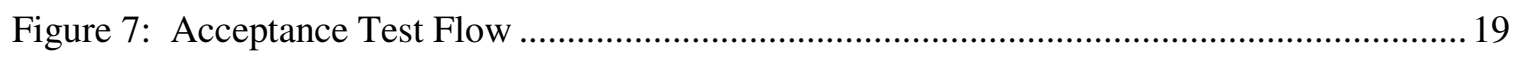

\section{List of Appendix Figures}

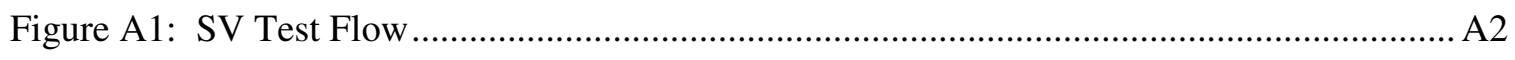

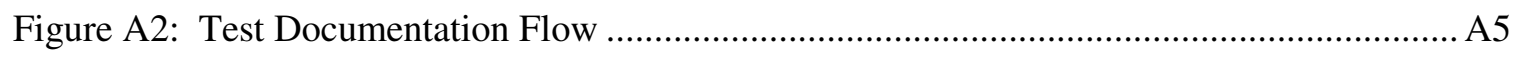

Figure A3: CubeSat System Diagram Example ................................................................ A25

Figure A4: CubeSat Bus Example ……….................................................................... A26

Figure A5: CubeSat Autonomous State Diagram Example ................................................. A42

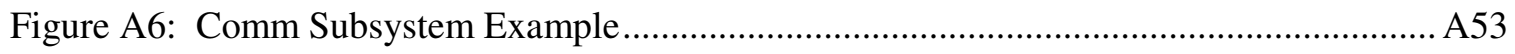




\section{List of Tables}

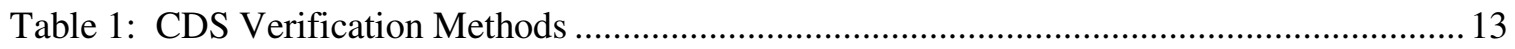

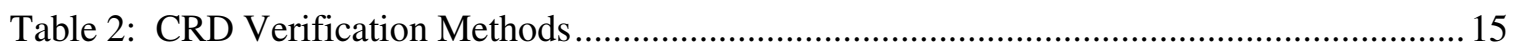

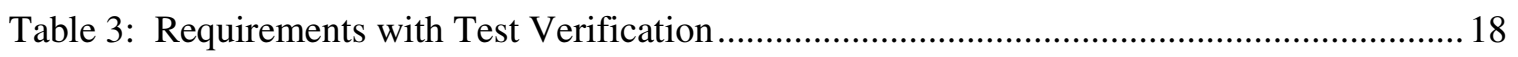

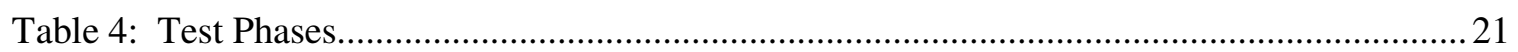

\section{List of Appendix Tables}

Table A1: Test Phases Numbering Conversion .................................................................. A11

Table A2: Test Requirement to REQID Traceability ...................................................... A2

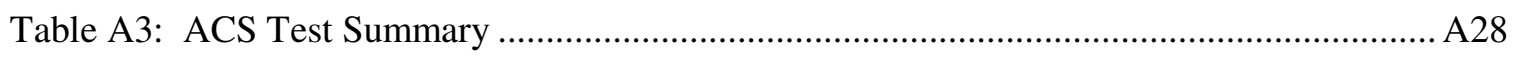

Table A4: C\&DH Subsystem Test Summary …….......................................................... A43

Table A5: Comm Subsystem Test Summary ...................................................................... A53

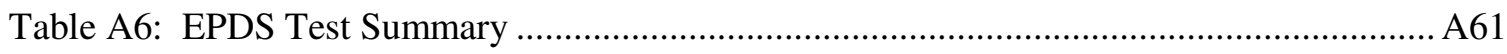

Table A7: Payload Subsystem Test Summary ................................................................ A74

Table A8: Structures \& Thermal Subsystem Test Summary .................................................. A78 


\section{List of Acronyms}

$\underline{\text { Acronym }}$

A

ACS

BIST

$\mathrm{C} \& \mathrm{DH}$

Cal Poly

CDS

CoFR

Comm

CONOPS

COTS

CRD

EGSE

ELV

EMC

EMI

EPDS

D

FCT

FIST

FSW

GEVS

\section{Definition}

Analysis

Attitude Control Subsystem

Baseline Integrated System Test

Command and Data Handling Subsystem

California Polytechnic State University, San Luis Obispo

CubeSat Design Specification

Certification of Flight Readiness

Communication Subsystem

Concept of Operations

Commercial Off the Shelf

Program Level Poly Picosatellite Orbital Deployer (PPOD) and CubeSat Requirements Document

Electrical Ground Support Equipment

Expendable Launch Vehicle

Electromagnetic Compatibility

Electromagnetic Interference

Electric Power Distribution Subsystem

Demonstration

Factory Confidence Test

Final Integrated System Test

Flight Software

General Environmental Verification Standard 


\begin{tabular}{|c|c|}
\hline Acronym & Definition \\
\hline GSE & Ground Support Equipment \\
\hline GSFC & Goddard Space Flight Center \\
\hline I & Inspection \\
\hline ICD & Interface Control Document \\
\hline ISO & International Organization for Standardization \\
\hline LBCT & Launch Base Confidence Test \\
\hline LSP & Launch Services Program \\
\hline LV & Launch Vehicle \\
\hline MGSE & Mechanical Ground Support Equipment \\
\hline MIL & Military \\
\hline N/A & Not Applicable \\
\hline NASA & National Aeronautics and Space Administration \\
\hline NDA & Non-Disclosure Agreement \\
\hline PIST & Preliminary Integrated System Test \\
\hline PPOD & Poly Pico-satellite Orbital Deployer \\
\hline RBF & Remove Before Flight \\
\hline REQID & Requirement Identification \\
\hline Rev & Revision \\
\hline RF & Radio Frequency \\
\hline RVTM & Requirements Verification Traceability Matrix \\
\hline SSDL & Space Systems Development Lab \\
\hline STD & Standard \\
\hline SV & Space Vehicle \\
\hline
\end{tabular}


$\underline{\text { Acronym }}$

T

TRD

TRR

TVAC

U.S. $\underline{\text { Definition }}$

Test

Test Requirements Document

Test Readiness Review

Thermal Vacuum

United States of America 


\section{Introduction}

The verification process is a fundamental systems engineering process required for the success of spacecraft design, fabrication and mission life cycle. As spacecraft in flight are not recoverable or repairable, a rigorous verification process will ensure the spacecraft performs as designed reducing the risk of on orbit failure from loss of equipment or mission capability. A combination of verification methods are used at various spacecraft assembly levels. This thesis will focus on the system level verification method of testing, providing requirements decomposition, test requirement definition and the recommended test execution phases.

\subsection{Purpose and Scope}

This thesis documents a pico-satellite test program, using the CubeSat Project as a baseline, with the structure necessary to provide evidence of requirements verification. It will provide the appropriate test requirements decomposed from the CubeSat system requirements. This document will also detail the recommended test phases and flow where tests should be executed. This will help provide an initial baseline for tracking on-orbit performance versus pre-launch capabilities.

\subsection{CubeSat Program}

The CubeSat Program is a collaborative effort between California Polytechnic State University, San Luis Obispo (Cal Poly), and Stanford University’s Space Systems Development Laboratory (SSDL). The purpose of the program is to establish a standard pico-satellite design which reduces cost and development time to increase accessibility to space. Since the CubeSat Program was started in 1999, it has grown to include hundreds of universities, high schools and private firms. CubeSats also incorporate scientific, private and government payloads. The CubeSat Program consists of three main components, the CubeSat, the Poly Pico-satellite Orbital Deployer 
(PPOD) and the Launch Vehicle (LV). Figures 1 through 4 show a CubeSat, PPOD, LV and PPOD integration scheme into a LV, respectively.

The primary mission of the CubeSat Program is to provide access to space for small payloads. A CubeSat contains a payload which demonstrates a new technology or provides tools for scientific research. Figure 1 shows multiple CubeSats. Cal Poly is the developer of the PPOD which interfaces with the LV and deploys the CubeSats. The primary mission of the PPOD is to ensure the safety and protection of the CubeSats, LV and the LV's primary payload. Figure 2 depicts a PPOD and Figure 4 depicts one method for PPOD integration into the LV. The LV provides the Certification of Flight Readiness (CoFR) for each PPOD allowing them to fly on National Aeronautics and Space Administration (NASA) Expendable Launch Vehicle (ELV) missions. Figure 3 depicts a representative LV launch.

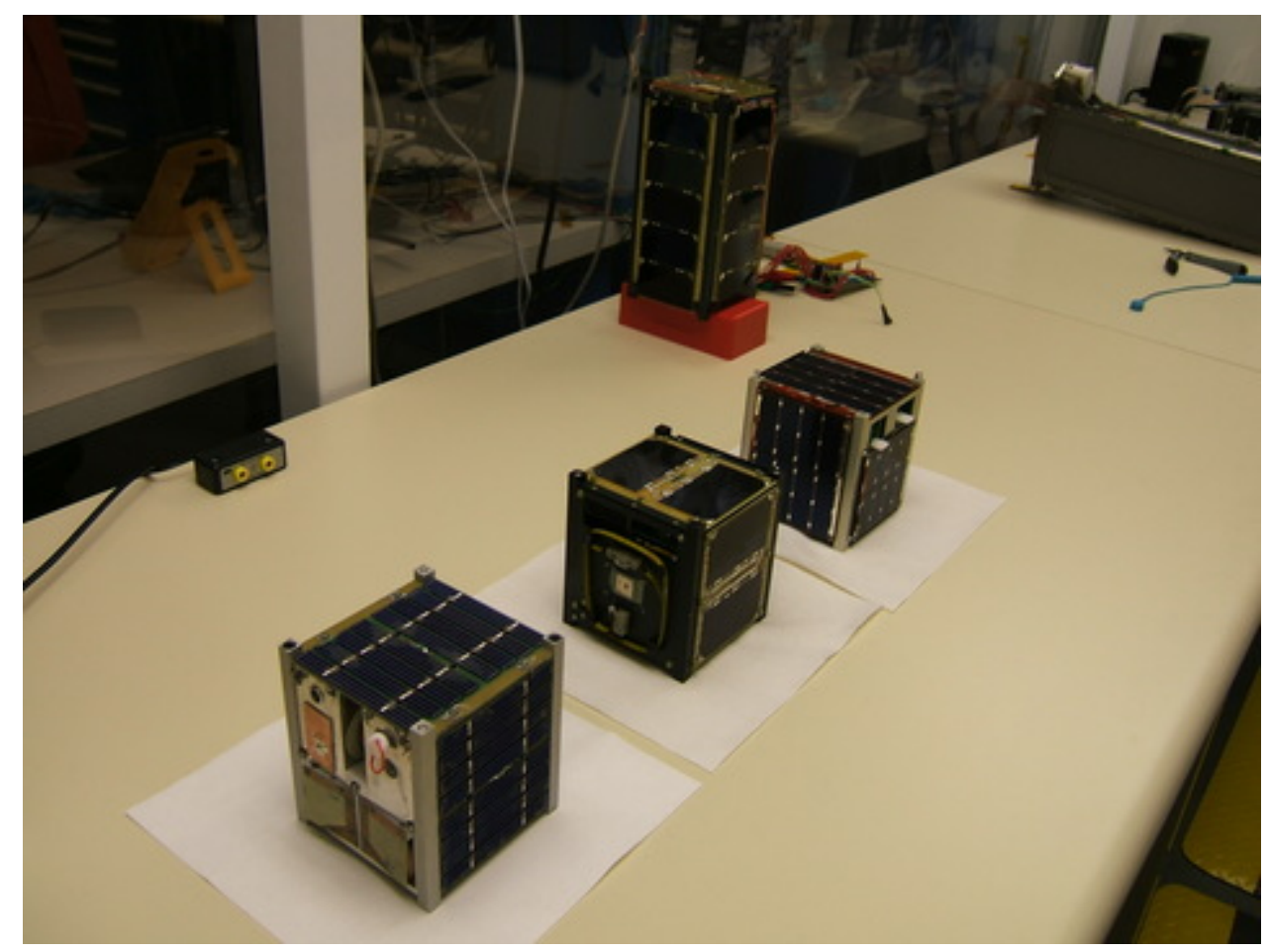

Figure 1: CubeSat Examples

Figure courtesy of www.cubesat.org 


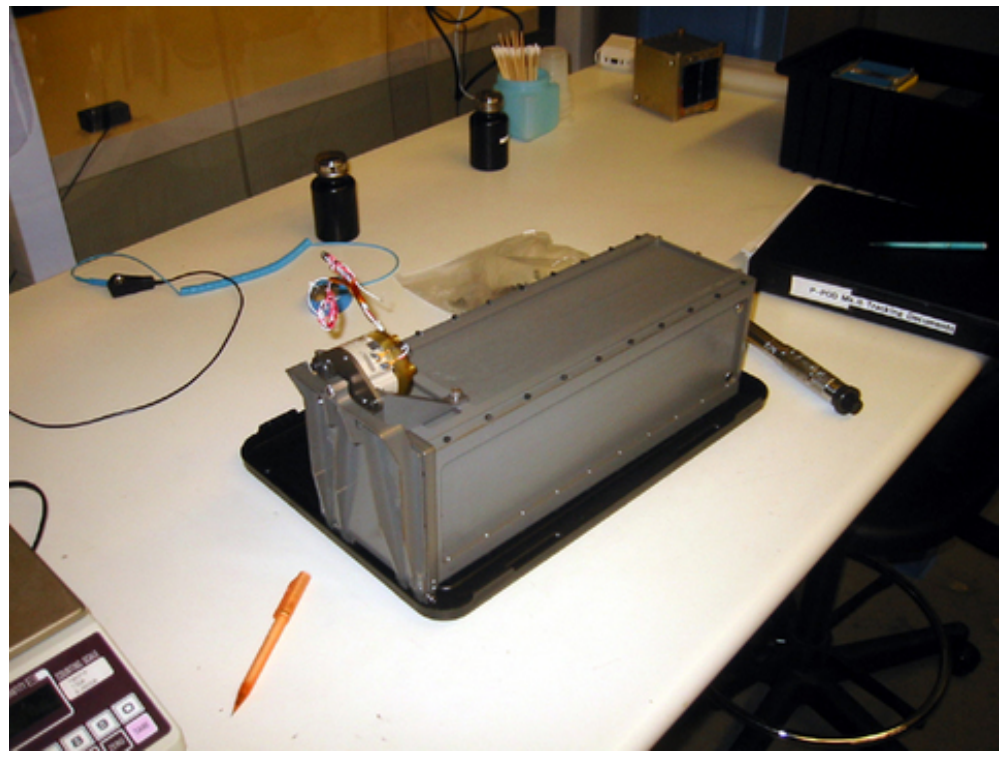

Figure 2: PPOD Example

Figure courtesy of www.cubesat.org

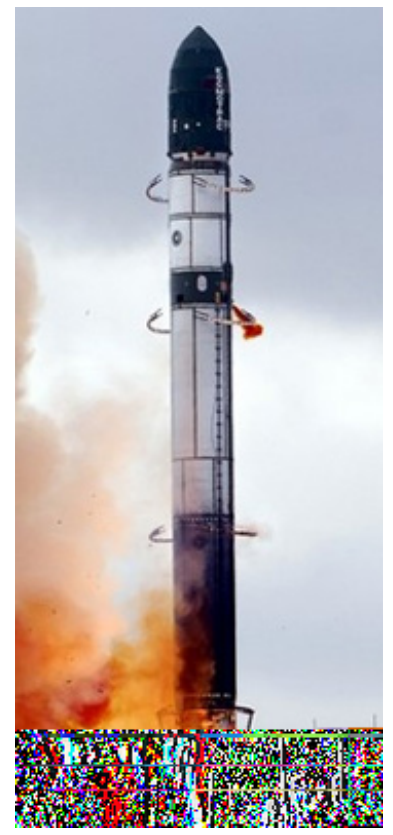

Figure 3: LV Example

Figure courtesy of www.cubesat.org 


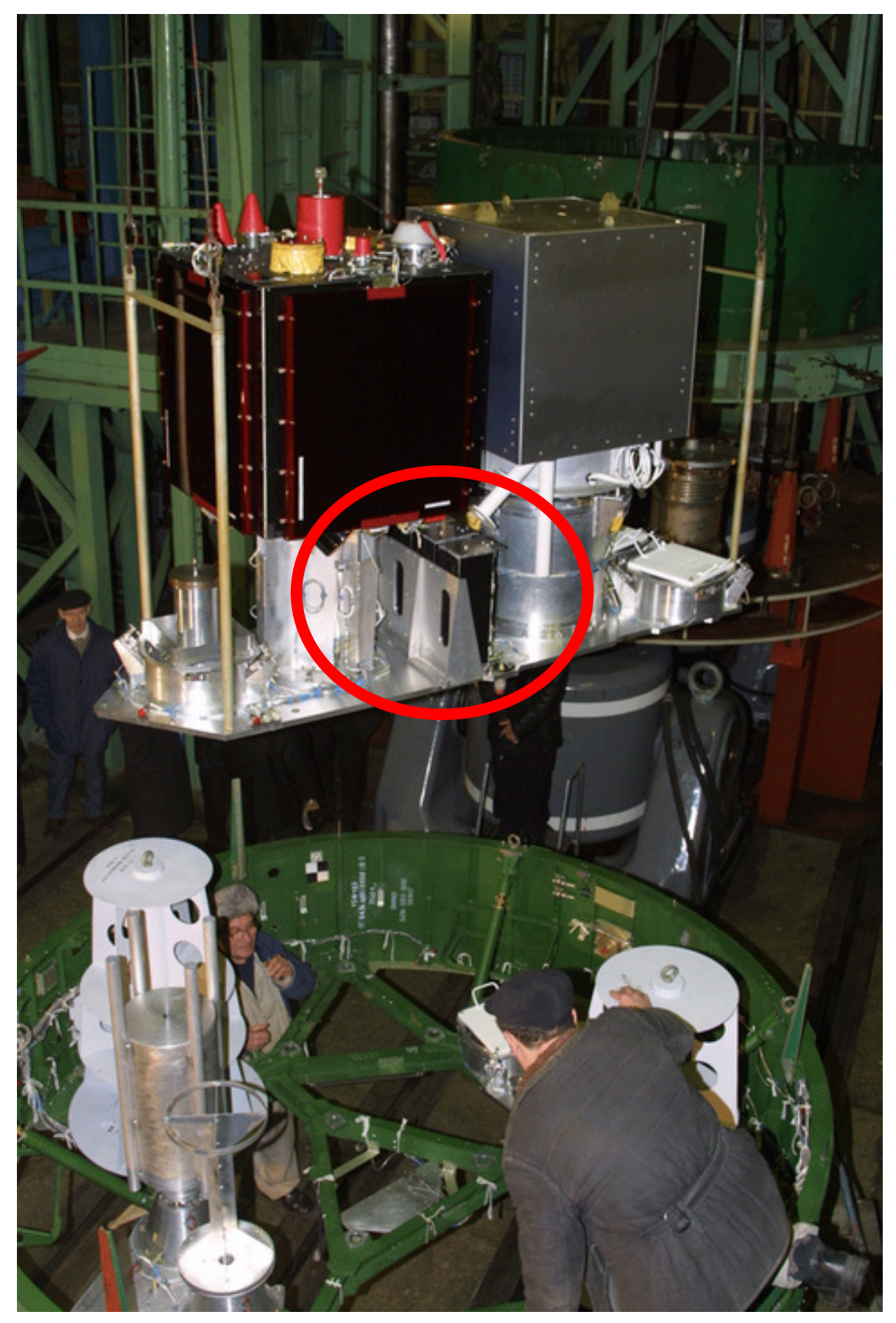

Figure 4: PPOD Integrated to LV

Figure courtesy of www.cubesat.org 


\subsection{Systems Engineering Approach}

Systems engineering is an interdisciplinary approach and means to enable the realization of successful systems [11]. Systems engineering emerged as a way to effectively manage complexity and change in systems. Systems engineering takes stakeholder needs, which are often broad in scope and unbounded, and decompose them into actionable, verifiable requirements. This ensures the system is built correctly and the right system is built to meet the stakeholder's needs. Driving the verification process is one core function of systems engineering.

\subsection{Verification Method}

The purpose of the verification process is to prove all requirements are satisfied by the system.

Figure 5 demonstrates the verification process [11].

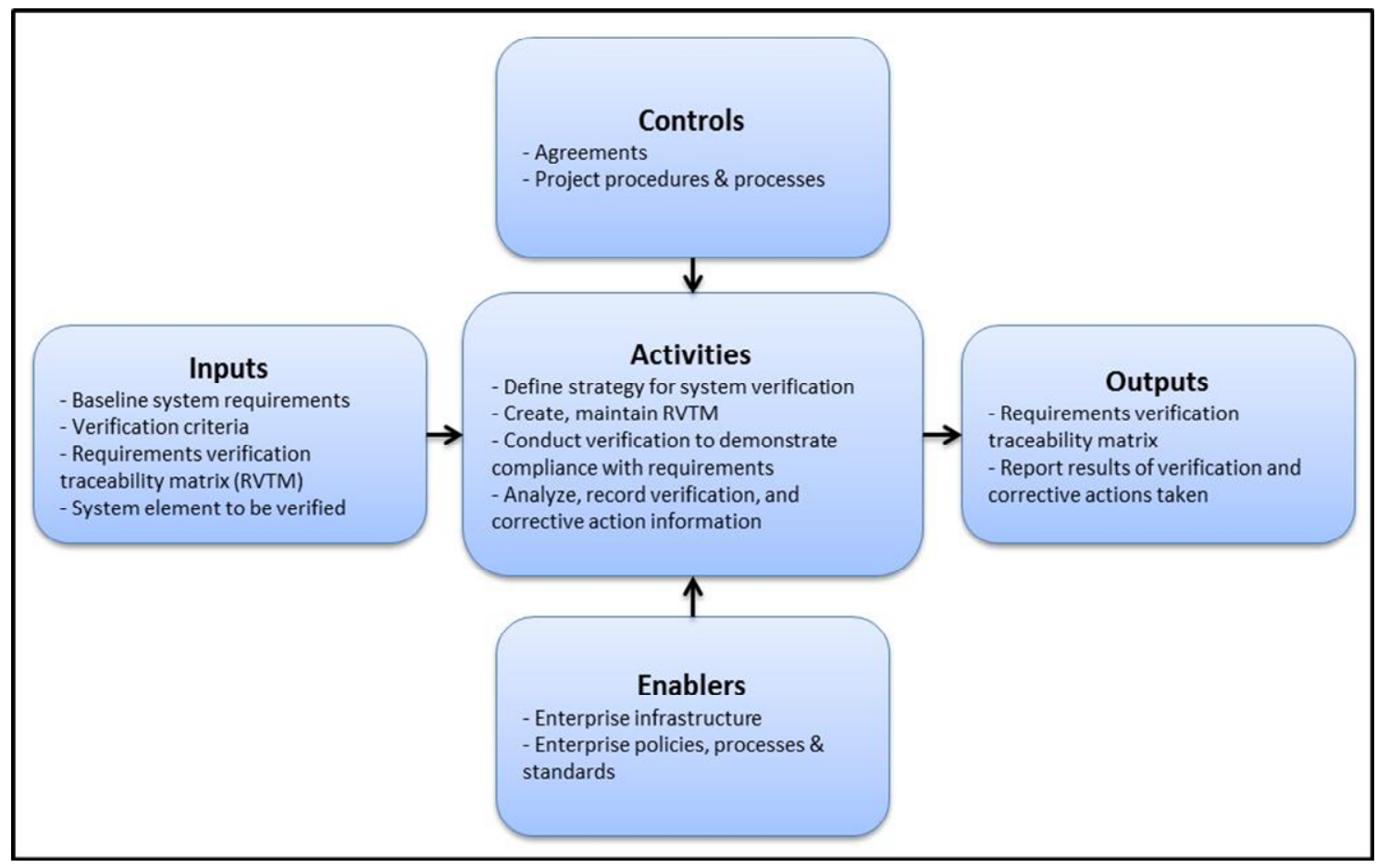

Figure 5: Verification Process 
Components, subsystems and systems are verified against the baseline requirements and the information is maintained in the Requirements Verification Traceability Matrix (RVTM). Verification ensures components, subsystems and systems meet their intended function and performance allocations and will maintain their capabilities through the life cycle. Verification methods include:

- Analysis: Perform modeling, simulation and/or statistical evaluation and analyzing the results. Determine qualitative and quantitative properties and performance by studying and examining engineering drawings, software/hardware flow diagrams, specifications or other documentation. Analysis techniques include interpretations or interpolation/extrapolation of analytical or empirical data under defined conditions, or reasoning to show compliance with requirement.

- Inspection: Investigation, without the use of special laboratory appliances or procedures, to determine compliance with requirements. Inspection may be accomplished by visual inspections of previous test data, test procedures, specifications or drawings to determine quantitative and/or qualitative properties of the hardware such as dimensional requirements, tolerances, workmanship, identification and envelopes.

- Demonstration: Exercising or operating the system or a part of the system without the aid of any special test equipment as in the case of a test. Sufficient data for requirements verification can be obtained by observing functional operation of the system or a part of the system.

- Similarity: Used in combination with another verification method, usually analysis, to show that the component is similar to another that has already been qualified to equivalent or more stringent criteria. 
- $\quad \underline{T e s t}:$ Exercising or operating the system or a part of the system in order to measure specific responses using specialized instrumentation that is not an integral part of the system being verified. Test may require the system to be active and subjected to controlled conditions that represent real or simulated operational parameters. The test method by its nature generates data, which is recorded by the instrumentation, test equipment or procedures. Analysis or review is performed on the data derived from the testing. This analysis is an integral part of this method and should not be confused with the analysis method described above.

Verification activities are determined and documented during the design and requirements definition phase of the program. Requirements are often verified using a combination of methods such as analysis and test or analysis and inspection. Verification activities can be performed at various levels of the system's assembly from components to fully integrated systems. It is more cost efficient to perform verification activities at lower assembly levels to enable detection of manufacturing defects, assembly or process errors, or unit underachieving performance requirements. This allows for a reduction in the amount of rework, disassembly or risk if a component fails. Verification activities are documented in detailed analysis, test or qualification plans and procedures.

\subsection{Test Requirement Verification}

Test requirements are established for design, performance and manufacturing verification (qualification) and for product verification (acceptance). A combination of test methods at levels of product assembly ranging from components through the fully assembled vehicle will be selected to prove design margins, validate manufacturing processes and verify products are free of latent defects [9]. There are also designations for specific types of tests which include: 
- Acceptance Test: Conducted prior to transition such that the customer can decide that the system is ready to change ownership status from supplier to acquirer.

- Development Test: Conducted on new items to demonstrate proof of concepts of feasibility.

- Operational Test: Conducted to verify the item meets its specification requirements when subjected to the actual operational environments.

- Protoflight Test: Applied when no qualification hardware is available. Used to prove the design on the first article produced has a predetermined margin above expected operating conditions but typically less then qualification levels.

- Qualification Test: Tests are conducted to prove the design on the first article produced, has a predetermined margin above expected operating conditions, for instance by using elevated environmental conditions for hardware.

It should be noted that acceptance tests, inspections and procedures shall be developed for hardware ranging from units through integrated systems. The verification objective is to demonstrate that flight items are free of defects and integration errors and are ready for operational use. This phase also includes recertification in case the flight configuration is disassembled due to failure or repair actions [9]. 


\section{Requirements Decomposition}

\subsection{Stakeholder Requirements}

In order to determine the system requirements, and subsequently the test requirements, we must first analyze all requirements to determine how they flow through the system and how they will be verified. System requirements come either directly or indirectly (decomposed) from the stakeholder requirements. Stakeholders are any individual or organization with a legitimate interest in the system. Typical stakeholders include operators, enterprise decision-makers, parties to the agreement, regulatory bodies and society-at-large [11]. In the case of the CubeSat Program, stakeholder examples include the Cal Poly students and payload designers, CubeSat Program investors and leadership and NASA ELV.

Once the stakeholder requirements have been documented, the requirements analysis process can begin. This process reviews, assesses and prioritizes all stakeholder and derived requirements, including constraints, to develop the functional and performance requirements by which the system will be designed and built to satisfy. The CubeSat Program has two primary requirement documents:

- CubeSat Design Specification (CDS)

- Program Level Poly Picosatellite Orbital Deployer (PPOD) and CubeSat Requirements Document (CRD) by the Launch Services Program

It should be noted these are not the only requirements for the CubeSat Program. If additional stakeholder requirements are levied they should be incorporated into this document. One prime example is the requirements detail in an Interface Control Document (ICD). ICDs are used to define interfaces between systems. As many ICDs are unique to specific pico-satellites, payloads 
and LVs, they often require Non-Disclosure Agreements (NDA). As a result, they could not be included in this document.

With the high level system requirements defined, requirements decomposition may begin. Requirements decomposition is the act of allocating system performance and functional requirements to subsystems and components. An example would be to allocate a system level imaging requirement to the Attitude Control Subsystem (ACS), Command \& Data Handling Subsystem $(\mathrm{C} \& D H)$ and Payload. Figure 6 demonstrates this simple example with a block diagram structure.

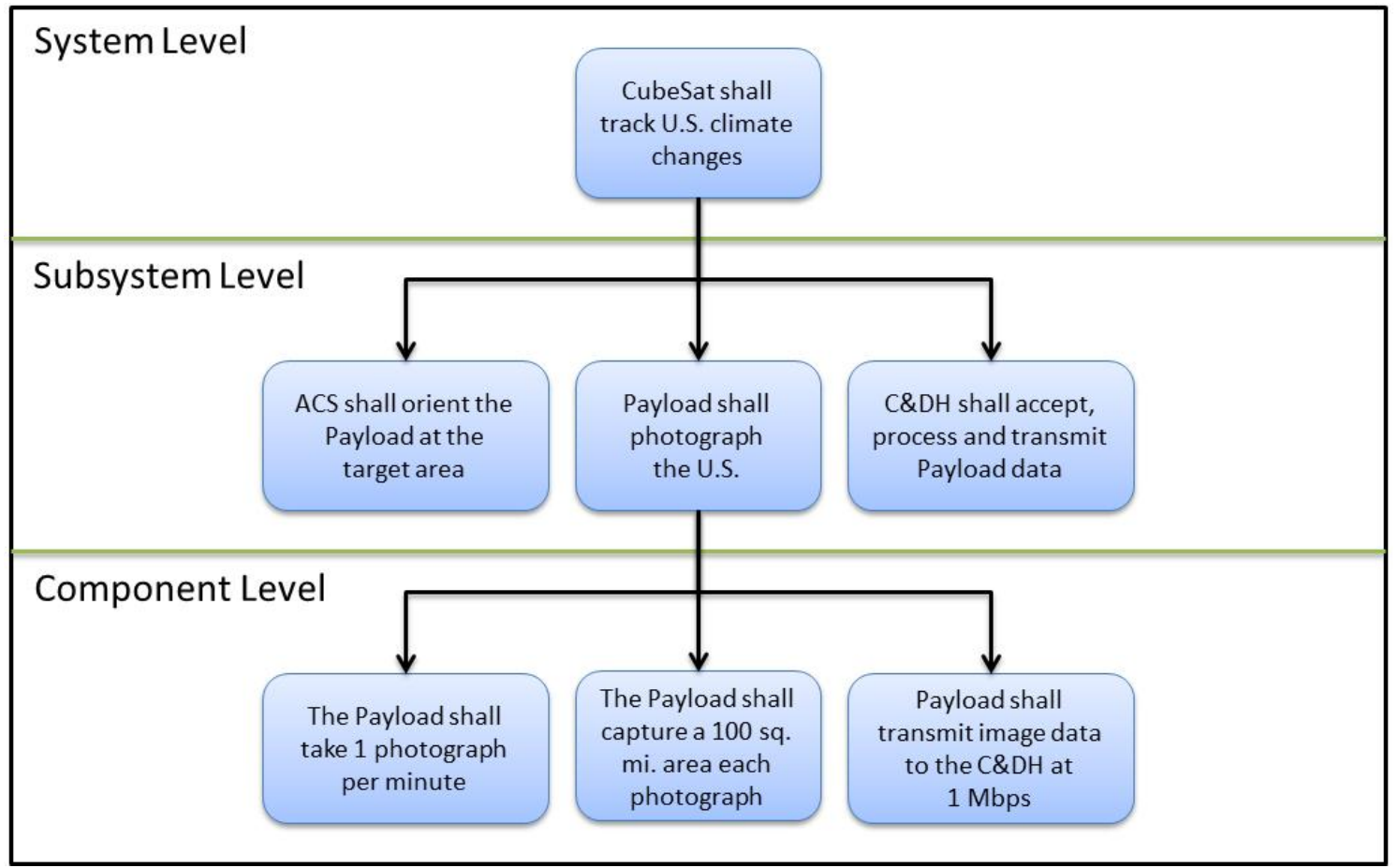

Figure 6: Requirement Decomposition Example 


\subsection{Program Requirements}

In addition to stakeholder requirements, there are program requirements. Program requirements are those levied on the program by the corporation, leadership, individuals or industry and are meant to establish standards of practice and ensure personnel safety. Examples of these types of requirements are the ISO 9001 requirements. ISO 9001 establishes processes for documentation and quality management which can be followed by any company or program. Since the CubeSat Program uses NASA LVs as a means of space access, other specifications, standards and requirements should be taken into account during the requirements decomposition process.

MIL-STD-1540D, Product Verification Requirements for Launch, Upper Stage, and Space Vehicles, is a standard developed by the Department of Defense to provide guidance on requirement allocation, verification methodologies, testing and risk management. Adherence to the processes in MIL-STD-1540D involves performing various tasks in different program phases applying a bottom-up verification process from unit to system level. This document includes the processes specific to system level verification and acceptance testing as detailed in MIL-STD1540D to ensure compliance.

For the Cal Poly CubeSat, most requirements have already been decomposed into subsystem and component requirements and therefore will not be duplicated here. Once the requirements have been properly decomposed the verification method can be derived. 


\section{Requirement Verification Methods}

\subsection{Program Tailoring}

The intent of this document is to provide a general yet structured method for verifying picosatellite system level test requirements. This document should be tailored to reflect the hardware, mission objectives, risk posture, complexity and other characteristics specific to each picosatellite. Examples of tailoring include additional testing of redundant systems, extensive deployable mechanism or modified shock level due to using a different LV.

\subsection{CDS Verification Methods}

The CubeSat Design Specification (CDS) lists the system level requirements each CubeSat must meet. Using the guidelines in Section 1.4 for verification method definitions of Analysis, Demonstration, Inspection and Test, Table 1 details the verification method used for each requirement of the CDS. As the verification method of Similarity is only used in specific instances, it is omitted from the verification methods used. The table references the section (or requirement) numbers and denotes the verification method abbreviated as A, D, I and T. As a reminder, it is possible for requirements to have multiple verification methods. Any number that is only a section heading will not have a verification method and will be denoted as not applicable (N/A). 


\begin{tabular}{|l|c|c|c|c|c|}
\hline \multicolumn{5}{|c|}{ Table 1: CDS Verification Methods } \\
\hline \multirow{2}{*}{$\begin{array}{c}\text { Section } \\
\text { Number }\end{array}$} & \multicolumn{5}{|c|}{ Verification Method } \\
\cline { 3 - 6 } & A & D & I & T & N/A \\
\hline 1. & & & & & $\mathrm{X}$ \\
\hline 1.1 & & & & & $\mathrm{X}$ \\
\hline 1.2 & & & & & $\mathrm{X}$ \\
\hline 1.3 & & & & & $\mathrm{X}$ \\
\hline 1.4 & & & & & $\mathrm{X}$ \\
\hline 2. & & & & & $\mathrm{X}$ \\
\hline 2.1 & & & & & $\mathrm{X}$ \\
\hline 2.1 .1 & & & $\mathrm{X}$ & & \\
\hline 2.1 .2 & & & & $\mathrm{X}$ & \\
\hline 2.1 .3 & & & $\mathrm{X}$ & & \\
\hline 2.1 .4 & & & $\mathrm{X}$ & & \\
\hline 2.1 .4 .1 & $\mathrm{X}$ & & & & \\
\hline 2.1 .5 & $\mathrm{X}$ & & & & \\
\hline 2.1 .6 & & & $\mathrm{X}$ & & \\
\hline 2.1 .7 & & & & & $\mathrm{X}$ \\
\hline 2.1 .7 .1 & & & $\mathrm{X}$ & $\mathrm{X}$ & \\
\hline 2.1 .7 .2 & & & $\mathrm{X}$ & $\mathrm{X}$ & \\
\hline 2.1 .7 .3 & & & & & $\mathrm{X}$ \\
\hline 2.1 .8 & & & $\mathrm{X}$ & & \\
\hline 2.1 .8 .1 & & & & & $\mathrm{X}$ \\
\hline 2.2 & & & & & $\mathrm{X}$ \\
\hline 2.2 .1 & & & & & $\mathrm{X}$ \\
\hline 2.2 .2 & & & $\mathrm{X}$ & & \\
\hline 2.2 .3 & & & $\mathrm{X}$ & & \\
\hline 2.2 .4 & & & $\mathrm{X}$ & & \\
\hline 2.2 .5 & & & $\mathrm{X}$ & & \\
\hline 2.2 .5 .1 & & & $\mathrm{X}$ & & \\
\hline 2.2 .6 & & & $\mathrm{X}$ & & \\
\hline 2.2 .7 & & $\mathrm{X}$ & $\mathrm{X}$ & & \\
\hline 2.2 .8 & & & $\mathrm{X}$ & & \\
\hline 2.2 .9 & & & $\mathrm{X}$ & & \\
\hline 2.2 .10 & & & & $\mathrm{X}$ & \\
\hline 2.2 .11 & & & $\mathrm{X}$ & & \\
\hline 2.2 .12 & & & $\mathrm{X}$ & & \\
\hline 2.2 .13 & & & $\mathrm{X}$ & & \\
\hline 2.2 .13 .1 & & & $\mathrm{X}$ & & \\
\hline 2.2 .13 .2 & & & $\mathrm{X}$ & & \\
\hline 2.2 .14 & & & & & $\mathrm{X}$ \\
\hline 2.2 .15 & & & & $\mathrm{X}$ & \\
\hline 2.2 .16 & & & & $\mathrm{X}$ & \\
\hline & & & & \\
\hline
\end{tabular}




\begin{tabular}{|l|c|c|c|c|c|}
\hline \multicolumn{5}{|c|}{ Table 1: CDS Verification Methods } \\
\hline \multirow{2}{*}{$\begin{array}{c}\text { Section } \\
\text { Number }\end{array}$} & \multicolumn{5}{c|}{ Verification Method } \\
\cline { 3 - 6 } & A & D & I & T & N/A \\
\hline 2.2 .17 & & & & $\mathrm{X}$ & \\
\hline 2.2 .18 & & & & & $\mathrm{X}$ \\
\hline 2.2 .19 & & & $\mathrm{X}$ & & \\
\hline 2.2 .20 & & & $\mathrm{X}$ & & \\
\hline 2.2 .21 & $\mathrm{X}$ & & $\mathrm{X}$ & $\mathrm{X}$ & \\
\hline 2.2 .21 .1 & & $\mathrm{X}$ & & & \\
\hline 2.2 .21 .2 & & & & $\mathrm{X}$ & \\
\hline 2.2 .21 .3 & & & $\mathrm{X}$ & & \\
\hline 2.3 & & & & & $\mathrm{X}$ \\
\hline 2.3 .1 & & $\mathrm{X}$ & & & \\
\hline 2.3 .2 & & $\mathrm{X}$ & & & \\
\hline 2.3 .2 .1 & & $\mathrm{X}$ & & & \\
\hline 2.3 .3 & & & $\mathrm{X}$ & & \\
\hline 2.3 .3 .1 & & & $\mathrm{X}$ & & \\
\hline 2.3 .3 .2 & & & $\mathrm{X}$ & & \\
\hline 2.3 .4 & & & $\mathrm{X}$ & & \\
\hline 2.3 .4 .1 & & & $\mathrm{X}$ & & \\
\hline 2.3 .4 .1 .1 & & & $\mathrm{X}$ & & \\
\hline 2.3 .4 .2 & & $\mathrm{X}$ & & & \\
\hline 2.3 .4 .3 & & & $\mathrm{X}$ & & \\
\hline 2.4 & & & & & $\mathrm{X}$ \\
\hline 2.4 .1 & & & & $\mathrm{X}$ & \\
\hline 2.4 .2 & & & & $\mathrm{X}$ & \\
\hline 2.4 .3 & & & & $\mathrm{X}$ & \\
\hline 2.4 .4 & & & $\mathrm{X}$ & & \\
\hline 2.4 .4 .1 & & & $\mathrm{X}$ & & \\
\hline 2.4 .5 & $\mathrm{X}$ & & & & \\
\hline 2.4 .5 .1 & & & $\mathrm{X}$ & & \\
\hline 2.4 .6 & & $\mathrm{X}$ & $\mathrm{X}$ & & \\
\hline 3. & & & & & $\mathrm{X}$ \\
\hline 3.1 & & & & $\mathrm{X}$ & \\
\hline 3.2 & & & $\mathrm{X}$ & & \\
\hline 3.3 & & & & & $\mathrm{X}$ \\
\hline 3.4 & & & & $\mathrm{X}$ & \\
\hline 3.5 & & & & & $\mathrm{X}$ \\
\hline 3.6 & & & & & $\mathrm{X}$ \\
\hline 4. & & & & & \\
\hline & & & & & \\
\hline
\end{tabular}




\subsection{CRD Verification Methods}

The Program Level Poly Picosatellite Orbital Deployer (PPOD) and CubeSat Requirements Document (CRD) by the Launch Services Program list the system level requirements each CubeSat must meet to integrate to and fly aboard NASA LVs. Using the guidelines in Section 1.4 for verification method definitions of Analysis, Demonstration, Inspection and Test, Table 2 details the verification method to be used for each requirement of the CRD. As the verification method of Similarity is only used in specific instances, it is omitted from the verification methods used. The table references the section (or requirement) numbers and denotes the verification method abbreviated as A, D, I and T. As a reminder, it is possible for requirements to have multiple verification methods. Any number that is only a section heading will not have a verification method and will be denoted as not applicable (N/A).

As this document focuses on CubeSats and their testing specifically, requirements levied on the PPOD have been deemed not applicable. Additionally, the CRD includes requirements on how to properly interface with NASA Launch Services Program (LSP) for processes and documentation. This has also been designated as not applicable.

\begin{tabular}{|l|c|c|c|c|c|}
\hline \multicolumn{5}{|c|}{ Table 2: CRD Verification Methods } \\
\hline \multirow{2}{*}{$\begin{array}{c}\text { Section } \\
\text { Number }\end{array}$} & \multicolumn{5}{|c|}{ Verification Method } \\
\cline { 2 - 6 } & A & D & I & T & N/A \\
\hline 1. & & & & & $\mathrm{X}$ \\
\hline 1.1 & & & & & $\mathrm{X}$ \\
\hline 1.2 & & & & & $\mathrm{X}$ \\
\hline 1.3 & & & & & $\mathrm{X}$ \\
\hline 2. & & & & & $\mathrm{X}$ \\
\hline 2.1 & & & & & $\mathrm{X}$ \\
\hline 2.2 & & & & & $\mathrm{X}$ \\
\hline 3. & & & & & $\mathrm{X}$ \\
\hline 4. & & & & & $\mathrm{X}$ \\
\hline
\end{tabular}




\begin{tabular}{|c|c|c|c|c|c|}
\hline \multirow{2}{*}{$\begin{array}{l}\text { Section } \\
\text { Number }\end{array}$} & \multicolumn{5}{|c|}{ Verification Method } \\
\hline & $\mathbf{A}$ & D & I & $\mathbf{T}$ & N/A \\
\hline 5. & & & & & $X$ \\
\hline 5.1 & & & & & $X$ \\
\hline 5.1 .1 & & & & & $X$ \\
\hline 5.1 .2 & & & & & $\mathrm{X}$ \\
\hline 5.1 .3 & & & & & $\mathrm{X}$ \\
\hline 5.1 .4 & & & & & $\mathrm{X}$ \\
\hline 5.1 .5 & & & & & $\mathrm{X}$ \\
\hline 5.1 .6 & & & & & $X$ \\
\hline 5.1 .7 & & & & & $\mathrm{X}$ \\
\hline 5.1 .8 & & & & & $\mathrm{X}$ \\
\hline 5.1 .9 & & & & & $\mathrm{X}$ \\
\hline 5.1 .10 & & & & & $\mathrm{X}$ \\
\hline 5.1 .11 & & & & & $X$ \\
\hline 5.1 .12 & & & & & $\mathrm{X}$ \\
\hline 6. & & & & & $\mathrm{X}$ \\
\hline 6.1 & & & & & $\mathrm{X}$ \\
\hline 6.1 .1 & & & & & $\mathrm{X}$ \\
\hline 6.1 .2 & & & & & $\mathrm{X}$ \\
\hline 6.2 & & & & & $\mathrm{X}$ \\
\hline 6.2 .1 & $\mathrm{X}$ & & & $\mathrm{X}$ & \\
\hline 6.2 .2 & $\mathrm{X}$ & & & $\mathrm{X}$ & \\
\hline 6.2 .3 & & & $\mathrm{X}$ & & \\
\hline 6.2 .4 & & & $\mathrm{X}$ & & \\
\hline 6.2 .5 & & & $\mathrm{X}$ & & \\
\hline 6.2 .6 & & & $\mathrm{X}$ & & \\
\hline 6.2 .7 & & & $\mathrm{X}$ & & \\
\hline 6.2 .8 & & & $\mathrm{X}$ & & \\
\hline 6.2 .9 & & & $\mathrm{X}$ & & \\
\hline 6.2 .10 & & & & $\mathrm{X}$ & \\
\hline 6.2 .11 & & & $\mathrm{X}$ & & \\
\hline 6.2 .11 .1 & & & $\mathrm{X}$ & $\mathrm{X}$ & \\
\hline 6.2 .11 .2 & & & $\mathrm{X}$ & & \\
\hline 6.2 .12 & & & $\mathrm{X}$ & & \\
\hline 6.2 .13 & $\mathrm{X}$ & & & & \\
\hline 6.2 .14 & & & $\mathrm{X}$ & & \\
\hline 6.2 .15 & & & $\mathrm{X}$ & & \\
\hline 6.3 & & & & & $\mathrm{X}$ \\
\hline 6.3 .1 & & & & & $X$ \\
\hline 6.3 .2 & & & & & $X$ \\
\hline 6.3 .3 & & & & & $X$ \\
\hline 6.3 .4 & & & & & $X$ \\
\hline 6.3 .5 & & & & & $X$ \\
\hline
\end{tabular}




\begin{tabular}{|l|c|c|c|c|c|}
\hline \multicolumn{5}{|c|}{ Table 2: CRD Verification Methods } \\
\hline \multirow{2}{*}{$\begin{array}{c}\text { Section } \\
\text { Number }\end{array}$} & \multicolumn{5}{|c|}{ Verification Method } \\
\hline & \multirow{2}{*}{ A } & D & \multicolumn{1}{c|}{ I } & \multicolumn{1}{c|}{ T } & N/A \\
\hline 6.3 .6 & & & & & $\mathrm{X}$ \\
\hline 6.3 .7 & & & & & $\mathrm{X}$ \\
\hline 6.3 .8 & & & & & $\mathrm{X}$ \\
\hline 6.3 .9 & & & & & $\mathrm{X}$ \\
\hline 6.3 .10 & & & & & $\mathrm{X}$ \\
\hline 6.3 .11 & & & & & $\mathrm{X}$ \\
\hline 6.3 .12 & & & & & $\mathrm{X}$ \\
\hline 6.3 .13 & & & & & $\mathrm{X}$ \\
\hline 6.3 .13 .1 & & & & & $\mathrm{X}$ \\
\hline 6.3 .13 .2 & & & & & $\mathrm{X}$ \\
\hline 6.3 .14 & & & & & $\mathrm{X}$ \\
\hline 6.3 .15 & & & & & $\mathrm{X}$ \\
\hline 6.4 & & & & & $\mathrm{X}$ \\
\hline 6.4 .1 & & & & & $\mathrm{X}$ \\
\hline 6.4 .2 & & & & & $\mathrm{X}$ \\
\hline 6.4 .3 & & & & & $\mathrm{X}$ \\
\hline 6.4 .4 & & & & & $\mathrm{X}$ \\
\hline 6.4 .5 & & & & & $\mathrm{X}$ \\
\hline 6.4 .6 & & & & & $\mathrm{X}$ \\
\hline 6.4 .7 & & & & & $\mathrm{X}$ \\
\hline 6.4 .8 & & & & & $\mathrm{X}$ \\
\hline 6.4 .9 & & & & \\
\hline 6.4 .10 & & & & $\mathrm{X}$ \\
\hline 6.4 .11 & & & & \\
\hline 6.4 .12 & & & & \\
\hline
\end{tabular}

\subsection{Test Verification Methods}

As this document will focus on the testing verification method, Table 3 compiles the requirements from the CDS and CRD which are to be verified by test. These requirements are system level requirements meaning they apply to the CubeSat once assembled and therefore must be verified at the system level (e.g. environments). However, it is often required, or otherwise advised, that individual components or subsystem pass performance and environmental testing prior to system integration to ensure success. 


\begin{tabular}{|c|c|c|c|c|c|}
\hline \multirow{2}{*}{ Specification } & \multirow{2}{*}{$\begin{array}{l}\text { Section } \\
\text { Number }\end{array}$} & \multicolumn{4}{|c|}{ Verification Method } \\
\hline & & $\mathbf{A}$ & D & $\bar{I}$ & $\mathbf{T}$ \\
\hline \multirow{15}{*}{ CDS } & 2.1 .2 & & & & $\mathrm{X}$ \\
\hline & 2.1 .7 .1 & & & $\mathrm{X}$ & $\mathrm{X}$ \\
\hline & 2.1 .7 .2 & & & $\mathrm{X}$ & $\mathrm{X}$ \\
\hline & 2.2 .10 & & & & $\mathrm{X}$ \\
\hline & 2.2 .15 & & & & $X$ \\
\hline & 2.2 .16 & & & & $\mathrm{X}$ \\
\hline & 2.2 .17 & & & & $\mathrm{X}$ \\
\hline & 2.2 .21 & $\mathrm{X}$ & & $\mathrm{X}$ & $\mathrm{X}$ \\
\hline & 2.2.21.2 & & & & $\mathrm{X}$ \\
\hline & 2.4 .1 & & & & $\mathrm{X}$ \\
\hline & 2.4 .2 & & & & $\mathrm{X}$ \\
\hline & 2.4 .3 & & & & $\mathrm{X}$ \\
\hline & 3.1 & & & & $\mathrm{X}$ \\
\hline & 3.2 & & & & $\bar{X}$ \\
\hline & 3.5 & & & & $\mathrm{X}$ \\
\hline \multirow{4}{*}{ CRD } & 6.2 .1 & $\mathrm{X}$ & & & $\mathrm{X}$ \\
\hline & 6.2 .2 & $\mathrm{X}$ & & & $\mathrm{X}$ \\
\hline & 6.2 .10 & & & & $\mathrm{X}$ \\
\hline & 6.2 .11 .1 & & & $\mathrm{X}$ & $\mathrm{X}$ \\
\hline
\end{tabular}

In addition to the explicit requirements which must be verified by test, there are also implicit requirements, which test the function of the components, subsystems and system. These are not performance based and are done to verify functionality, workmanship and interfaces. Continuing the example used in Section 2.1 to illustrate this difference, the C\&DH passes commands to the Payload to take a photograph, after which the Payload sends the image date back to the C\&DH. A performance test would verify the quality of the picture, determine any system latency or 
understand the data transfer rate. A functional test would be to verify a command was sent from C\&DH and was received by the Payload. It ensures workmanship of the system, verifying interfaces of the system like electronic connections or power transfer.

Depending on the customer requirements, program processes, resource constraints and hardware availability the acceptance test flow can change. Qualification testing is used in conjunction with acceptance testing to verify the CubeSat exceeds the expected operation environments. However, when hardware is limited, the flight hardware can undergo protoflight testing which sets limit above acceptance test requirements but below qualification test requirements. This is done to reduce the amount of stressing to the flight unit. Figure 7 demonstrates the acceptance test flow as defined in LSP-REQ-317.01.

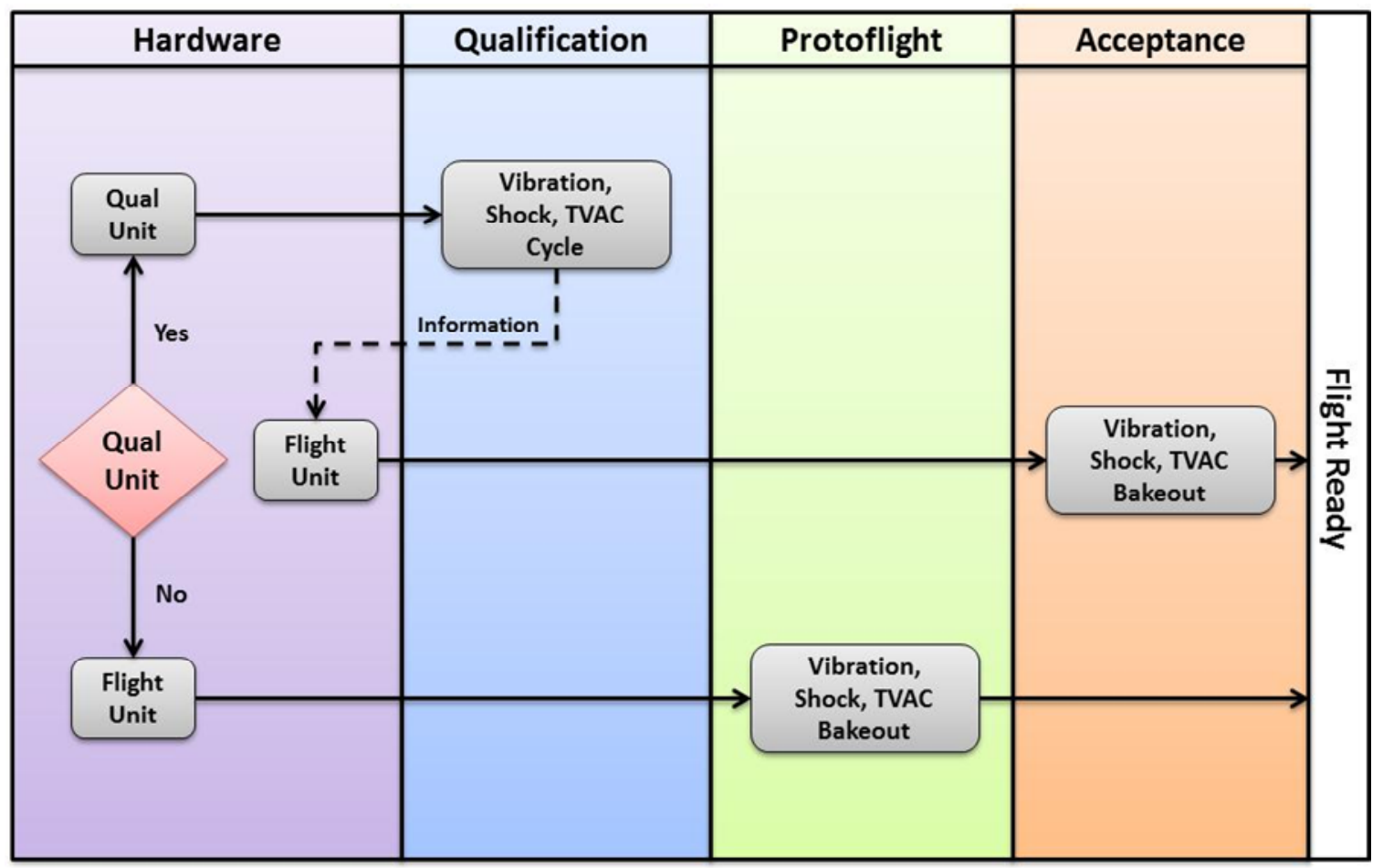

Figure 7: Acceptance Test Flow 


\section{Testing Methodology}

It is often preferred to perform testing at the lowest level possible. While full performance and functional testing can occur at the fully integrate system level, it is often much more expensive and induces higher risk to the program. Additionally, testing at lower levels may be required to induce the required stress to uncover design and workmanship flaws, something which may not be feasible at the system level. As testing seeks to reduce risk of failure, finding critical errors at the system level after components have been designed, fabricated and integrated can be detrimental to the program's cost and schedule. Whereas identifying errors at the component level allows for design changes, component swaps or repairs with minimal impact. This also reduces the necessity for personnel, time, support equipment and complicated testing. Generally, performance testing occurs at the component and subsystem level while functional tests occur at the subsystem and system level. The earlier testing and verification occurs the more successful a program will be.

This document focuses on the system level testing which comprises functional and environmental testing. It is assumed before a component is integrated into the system it meets the allocated performance requirements. This ensures verified components are integrated into the system reducing risk and narrowing failure root cause analysis in the event of a system or component failure.

\subsection{Testing Phases}

There are often multiple phases of testing. Phases define the CubeSat configuration and types of tests which will occur. Table 4 defines the major testing phases. 


\begin{tabular}{|c|c|}
\hline Test Phase & Phase Description \\
\hline Receiving / Assembly Test & $\begin{array}{l}\text { Verify the integrity of flight hardware } \\
\text { components prior to a complete SV } \\
\text { assembly commitment. }\end{array}$ \\
\hline Preliminary Integrated System Test (PIST) & $\begin{array}{l}\text { Demonstrates the flight hardware, } \\
\text { along with associated FSW, GSE and } \\
\text { procedures are ready for BIST. }\end{array}$ \\
\hline $\begin{array}{l}\text { Electromagnetic Interference / } \\
\text { Compatibility Test (EMI / EMC) }\end{array}$ & $\begin{array}{l}\text { Demonstrates that, under normal } \\
\text { operating conditions, the system } \\
\text { components do not have } \\
\text { electromagnetic interference (emission } \\
\text { and susceptibility). }\end{array}$ \\
\hline Baseline Integrated System Test (BIST) & $\begin{array}{l}\text { Perform a complete integrated system } \\
\text { test. Results will be compared to FIST } \\
\text { after environmental testing. }\end{array}$ \\
\hline Acoustic Test & $\begin{array}{l}\text { Demonstrates system performance } \\
\text { after exposure to expected launch level } \\
\text { acoustic environment. This includes } \\
\text { random vibration, sinusoidal vibration } \\
\text { and shock environments. }\end{array}$ \\
\hline Thermal Vacuum Test (TVAC) & $\begin{array}{l}\text { Demonstrates the ability to withstand } \\
\text { thermal environmental stressing. }\end{array}$ \\
\hline Final Integrated System Test (FIST) & $\begin{array}{l}\text { Demonstrates proper system } \\
\text { performance post environmental } \\
\text { testing. Duplicate of BIST testing. }\end{array}$ \\
\hline Final Mechanical Deploys & $\begin{array}{l}\text { Demonstrates proper functionality of } \\
\text { all mechanical deploying systems } \\
\text { prior to launch. }\end{array}$ \\
\hline Factory Confidence Test (FCT) & $\begin{array}{l}\text { Abbreviated integrated system test } \\
\text { performed to obtain a baseline of SV } \\
\text { performance before shipping to the } \\
\text { launch base. Ideal for instances where } \\
\text { the SV is stored prior to launch. }\end{array}$ \\
\hline Launch Base Confidence Test (LBCT) & $\begin{array}{l}\text { Performed to obtain an assessment of } \\
\text { SV performance after shipping to the } \\
\text { launch base. Duplicate of the FCT }\end{array}$ \\
\hline Fueling and Encapsulation & $\begin{array}{l}\text { Load propellant on the SV and } \\
\text { perform encapsulation of the } S V \text { in the } \\
\text { PPOD and fairing. }\end{array}$ \\
\hline Post Mate Tests & $\begin{array}{l}\text { After mating to the LV, perform any } \\
\text { final system tests (e.g. battery charge / } \\
\text { discharge). }\end{array}$ \\
\hline
\end{tabular}




\subsection{Test Verification Documentation}

It is important to properly document all testing requirements, activities and results. This includes the tests to be performed, what requirement the test satisfies, the documentation used to perform each test, test roles and responsibilities and the associated results. Appendix A will provide the guidelines for the recommended CubeSat system level test program. Called the Test Requirements Document (TRD), it details the appropriate requirements to be tested and in what phase(s) they should be tested based on the guidelines establish to this point. The TRD alone does not verify or validate the CubeSat is ready for flight, but is an integral part of demonstrating successful on-orbit function. 


\section{Bibliography}

[1] Bashbush, Veronica. Characterization of the Internal and External Environments of the CubeSat P-POD and Test Pod. M.S. Thesis. California Polytechnic State University Aerospace Engineering Department. January 2004.

[2] Bennett, Mike. Personal Conversation. 08 April 2011.

[3] Bland, Ivan. Receiver Sensitivity Characterization of the PolySat Satellite Communication System. M.S. Thesis. California Polytechnic State University Aerospace Engineering Department. June 2004.

[4] “CCS-100 CubeSat Communication Suite.” Space Quest, Ltd. August 2009. 02 October 2011 $<$ http://www.spacequest.com/products/CCS-100.pdf $>$.

[5] Claussen, Carl. Manufacturing, Integration, and Testing of Cal Poly's Third Pico-satellite. M.S. Thesis. California Polytechnic State University Aerospace Engineering Department. March 2007.

[6] Coelho, Roland. Email Correspondence. 12 April 2011.

[7] “COMS Block Diagram.” University of Leicester CubeSat Project. 10 August 2009. 23 October $2011<\mathrm{http} / / /$ cubesat.wikidot.com/coms-block-diagram>.

[8] "CubeSat Design Specification.” California Polytechnic State University CubeSat Project. 01 August 2009. April $2011<$ <ttp://cubesat.atl.calpoly.edu/media/CDS rev10.pdf>.

[9] Department of Defense Standard Practice. Product Verification Requirements for Launch, Upper Stage, and Space Vehicles. MIL-STD-1540D. 15 January 1999. 
[10] Galysh, I., K. Doherty , J. McGuire , H. Heidt , D. Niemi , and G. Dutchover. "CubeSat: Developing a Standard Bus for Picosatellites.” StenSat Group. 02 October 2011 $<$ http://www.cubesat.org/images/Papers/stensat_hist.pdf $>$.

[11] International Council on Systems Engineering. Systems Engineering Handbook; A Guide for System Life Cycle Processes and Activities. Volume 3. INCOSE-TP-2003-002-03. June 2006.

[12] Klofas, B.and J. Anderson. “A Survey of CubeSat Communication Systems.” California Polytechnic State University. November 2008. 17 September 2011 $<$ http://www.klofas.com/papers/CommSurvey-Bryan_Klofas.pdf>.

[13] National Aeronautics and Space Administration. Goddard Space Flight Center. General Environmental Verification Standard (GEVS) for GEVS Flight Programs and Projects. GSFC-STD-7000. June 1996.

[14] National Aeronautics and Space Administration. John F. Kennedy Space Center Launch Services Program. Program Level Poly Picosatellite Orbital Deployer (PPOD) and CubeSat Requirements Document. LSP-REQ-317.01. 24 July 2009.

[15] Noe, Chris. Design and Implementation of the Communications Subsystem for the Cal Poly CP2 Cubesat Project. B.S. Senior Project. California Polytechnic State University Aerospace Engineering Department. June 2004. 23 October 2011 $<$ http://www.polysat.calpoly.edu/PublishedPapers/ChrisNoe_srproj.pdf>.

[16] "PolySat CP2 System Overview." California Polytechnic State University Satellite Project. 01 October $2011<$ <ttp://polysat.calpoly.edu/CP2_docs.php>. 
[17] Puig-Suari, J., C. Turner, and W. Ahlgren. "Development of the Standard CubeSat Deployer and a CubeSat Class PicoSatellite.” California Polytechnic State University. 17 September $2011<$ <ttp://www.cubesat.org/images/Papers/cubesat_paper.pdf>.

[18] Schaffer, Jake. The Electronic System Design, Analysis, Integration, and Construction of the Cal Poly State University CP1 CubeSat. B.S Senior Project. California Polytechnic State University Aerospace Engineering Department. In: Proceedings of the 16th AIAA/USU Conference on Small Satellites. August 2002. 01 October 2011 $<$ http://www.cubesat.org/images/Papers/cp1_paper.pdf>.

[19] Williams, Austin. Email Correspondence. 2 August 2011.

[20] Worthley, Craig. Viability Study for Standarized, Commercial Off-the-Shelf Satellite Test Systems. M.S. Thesis. California Polytechnic State University Aerospace Engineering Department. June 2007. 
APPENDIX A: Pico-Satellite System Level Test Requirements Document 


\section{Pico-Satellite System Level \\ Test Requirements Document}

for

California Polytechnic State University, San Luis Obispo

by

Marcus A. Ruddy

February 13, 2012 


\section{Purpose and Scope}

This document defines the detailed test requirements associated with vehicle test verification of a general pico-satellite space vehicle (SV) architecture from receiving and assembly testing through testing at the launch base. Figure A1 demonstrates the SV test flow. Table A1 denotes the phases within. While all SVs may not require or accomplish every test phases shown, it represents a general flow for most SVs.

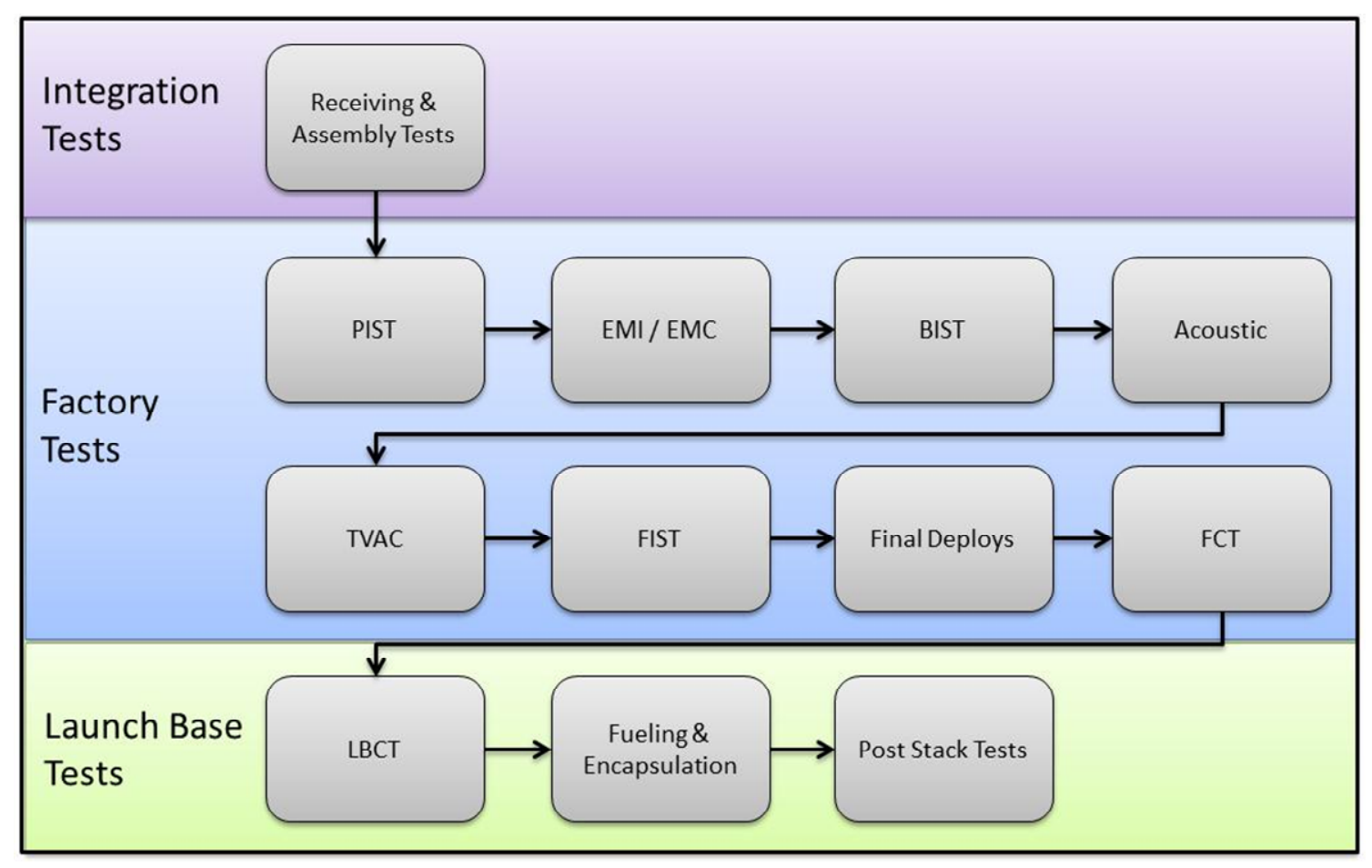

Figure A1: SV Test Flow

Since each pico-satellite is unique, this document provides the test requirements for a general SV configuration. Test requirement additions, omissions, updates or inclusions of specific payloads or components should be included to create a program specific version of this document. As an example, updates based on the variation between payloads or additions to account for increases in 
component or subsystem redundancy are obvious examples for document modifications.

However, updates to include component standby states are less apparent but impose large impacts to system performance. Depending on the pico-satellite's concept of operation, components may be left on continuously to simplify designs or be placed into a limited power use standby state. If a standby state is used, that functionality must be tested as failure will directly affect the power budget or mission capabilities. 


\section{Overview}

The Test Requirements Document (TRD) is the top-level SV test requirements document from which test plans, procedures and sequences are developed.

The TRD is developed using material from several sources. These sources include the CubeSat Design Specification (CDS) and Program Level Poly Picosatellite Orbital Deployer (PPOD) and CubeSat Requirements Document (CRD) by the Launch Services Program. Most of the detailed test requirements contained herein are derived. Some, however, flow from requirements specified in other program documentation. In addition to the review of requirements documents, CubeSat architectures were reviewed for functional and interface requirements. Where applicable, documentation with applicable test requirements should be evaluated for inclusion in the TRD.

The TRD provide the system level test requirements necessary for test plan and procedure development. Figure A2 illustrates the requirement verification documentation flow. 


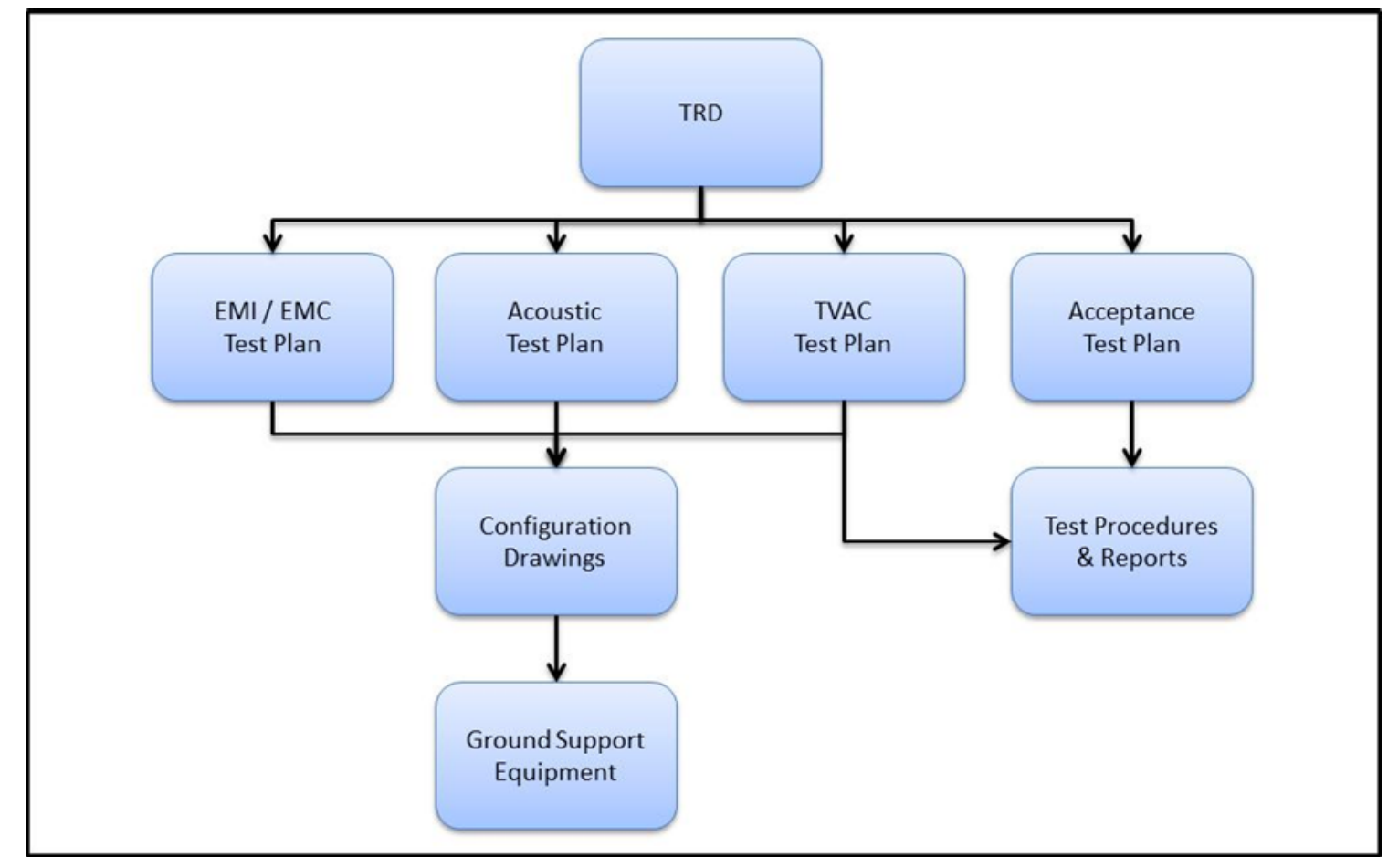

Figure A2: Test Documentation Flow

The TRD documents what SV test requirements, whether direct or derived, need be verified to ensure mission success. It does not document how the requirements are verified. The TRD requirements form the test structure and foundation for the various test plans and procedures used to perform the tests whereby requirements are verified. Test requirements are either flowed directly to the TRD or derived through analytical, functional or workmanship requirements. A SV's ability to withstand launch loads is an example of a requirement flowed directly to the TRD, whereas the ability of the SV to provide power to components is a derived requirement for the verification of SV's workmanship.

In Figure A2, test plans are used to document how the specific tests will be accomplished including the location, test configuration, or any other pertinent information required for successful execution of the test. While the TRD provides some of this information, the test plans 
should be more in depth. From the plans flow the test procedures, configuration drawings and requirements for ground support equipment (GSE) where applicable. The EMI / EMC, Acoustic, and TVAC Test Plans document how those specific sets of requirements in the TRD will be verified, the SV and facility configuration and data to be collected. The Acceptance Test Plan details how the requirements of PIST, BIST, FIST, FCT, and LBCT are verified.

In addition to performing the test phases described, it is often required by some organizations to accumulate a minimum amount of operational time prior to launch over the course of the test program. As this requirement is not specifically imposed, the more failure free performance testing accrued the better the architecture and components are understood thus simultaneously reducing the risk of on orbit failures. This is especially critical when using non-space qualified hardware like many commercial off the shelf (COTS) products. 


\section{Test Documentation}

For the requirements stated in this document, the items described below will support testing.

\subsection{Documentation Change Process}

Specification or documentation changes should be captured and controlled to ensure proper requirements verification. As specifications document the requirements for a system, any update or change should be reviewed for impacts to existing designs, procedures, processes or tests. Documentation should use and reference the latest version of all applicable documents upon release and be reviewed as part of the documentation change process. Having a regimented document change process will ensure all designs, tests and personnel are working to the latest set of requirements.

\subsection{Test Segment}

Portions of testing can be performed via automated test sequences, referred to as test segments. A test segment is software code designed to execute specific system functionality and collect data to support verifying requirements.

\subsection{Test Procedures}

SV testing will be performed via controlled test procedures. Test procedures and changes will be managed by each pico-satellite program. Test procedures are used to document the exact process used to configure, test and de-configure the SV. It also will serve as the documentation record for test data, notes, process changes or updates and witnessed anomalies.

\subsection{Test Discrepancies}

All anomalous test results will be documented in accordance with the individual pico-satellite program. While there are many ways to accomplish the documentation of test discrepancies it is 
recommended they be included in or attached to the as run test procedure as well as detailed in a program database.

While performing tests, it is important to catalog the test configuration, steps taken and any observables during the test discrepancy. Additionally, it is paramount that the test configuration remains intact and unchanged after the failure or discrepancy. The only exception would be to alter the configuration to ensure safety of all personnel. This precludes the potential for an unverified failure. An unverified failure is a discrepancy which cannot be duplicated making the cause or trigger unknown. Unverified failures add considerable risk to the system as the root cause cannot be determined. Proper documentation and freezing of the test configuration greatly accelerate troubleshooting and limit the chance of an unverified failure occurring.

\subsection{Test Reports}

After all verification activities a report should be generated to capture applicable data related to the test requirement verification. Test reports should include the as run test procedure, data with associated analysis, test discrepancies, and any other pertinent information.

\subsection{Test Readiness Reviews}

A test readiness review (TRR) should be convened at all major SV testing milestones (i.e. PIST, TVAC, etc). The purpose of the TRR is to ensure readiness to proceed to the next phase of testing. The TRR is the forum for reviewing phase entrance and exit criteria, requirements for hardware and software configuration, verification of test requirements and open discrepancies or risks. The purpose of the TRR is to verify that the flight hardware and software, GSE, facilities and personnel are ready to support the testing. Safety considerations, test sequence, methods, configuration, objectives, and proposed schedules should be presented for final review and concurrence. 


\section{Test Responsibilities}

The following paragraphs assign major system test program responsibilities for test execution.

\subsection{Test Lead}

The test lead is the person responsible for the execution of the test and the safety of all personal and hardware. They are the domain expert on the test itself, the support equipment and process.

\subsection{Engineering Lead}

The engineering lead is the component or system expert who has the most technical knowledge of the unit under test.

\subsection{Quality}

Quality ensures the test procedure is followed properly and all applicable data is recorded. They act as a second set of eyes to ensure the test is properly and safely executed. 


\section{Ground Support Equipment}

Ground Support Equipment (GSE) is used in support of test. There is typically Mechanical GSE (MGSE) and Electrical GSE (EGSE). MGSE encompasses SV handling or support fixtures or mechanical test aids external to the SV. EGSE and Test consoles are used to load software to the vehicle, emulate flight hardware and interfaces or provide data acquisition capabilities. They are integral to the test configuration and execution allowing for the automation of tests. All test plans should reference the GSE required for use in each test. Prior to GSE use, they are checked out and calibrated (e.g. verify power / signal of EGSE or certify ESD workstations or measurement tools) to ensure they do not introduce error or test discrepancies once mated to the components, subsystems or SV. 


\section{Test Phases}

The test program is broken down into the following major test phases as numbered in Table A1.

\begin{tabular}{|l|l|}
\hline \multicolumn{2}{|c|}{ Table A1: Test Phases Numbering Conversion } \\
\hline Number & Test Phase \\
\hline 1 & Receiving / Assembly Test \\
\hline 2 & Preliminary Integrated System Test (PIST) \\
\hline 3 & Electromagnetic Interference / Compatibility Test (EMI / EMC) \\
\hline 4 & Baseline Integrated System Test (BIST) \\
\hline 5 & Acoustic Test \\
\hline 6 & Thermal Vacuum Test (TVAC) \\
\hline 7 & Final Integrated System Test (FIST) \\
\hline 8 & Final Mechanical Deploys \\
\hline 9 & Factory Confidence Test (FCT) \\
\hline 10 & Launch Base Confidence Test (LBCT) \\
\hline 11 & Fueling and Encapsulation \\
\hline 12 & Post Mate Tests \\
\hline
\end{tabular}




\subsection{Receiving / Assembly Tests}

\subsubsection{Test Objectives}

The receiving / assembly test phase primarily addresses functionality before vehicle power on. These tests are expected to be accomplished prior to the "delivery" of the vehicle to system test. The intent of these tests is twofold. The first is to verify the integrity of flight hardware components prior to a complete SV assembly commitment. The second is to obtain baseline alignments / measurements necessary for future testing / operations. Examples of this type of testing are those performed on the solar cells prior to SV integration or optics alignments to be compared to alignments after SV integration.

This document provides a minimum set of receiving and assembly tests to be performed. It is assumed components are received from a subcontractor who has performed a complete requirements verification process on the supplied component. This means the components have been tested to verify they meet all performance requirements prior to components acceptance and delivery.

Assembly tests are performed on components while populating the pico-satellite. An example is to perform continuity and isolation tests on all cables prior to attachment to flight hardware.

Another is ground isolation tests during integration which detect shorts as they are introduced into the system. This allows for rapid troubleshooting during assembly instead of detecting failures in test after multiple components have been integrated.

\subsubsection{Test Preparation and Configuration Overview}

This phase of testing is performed on individual components or subsystems prior to system level integration and test. 


\subsection{Preliminary Integrated System Test (PIST)}

\subsubsection{Test Objectives}

The Preliminary Integrated System Test (PIST) phase is the first time the SV is tested at the fully assembled and integrated level. This testing provides the first look at functional interfaces, performance and workmanship. PIST is the test span in which the flight hardware and system test equipment are initially integrated and powered on using flight hardware and qualified flight software (FSW). This also established proper GSE and test segment operations on the SV. PIST allows troubleshooting of hardware and software ensuring future tests run smoothly. PIST demonstrates that the flight hardware, along with associated FSW, GSE and procedures, are ready for the subsequent BIST, the results of which will be used as a baseline of pre-environmental system performance to compare with results of the FIST in the selloff of the SV. The overarching goal of PIST is to demonstrate that a complete integrated system test can be successfully run prior to starting BIST.

While PIST is important as a first look at SV interfaces and workmanship as a risk mitigation effort, it can be removed entirely and not compromise the integrity of the test program or requirement verification. All testing in this phase is predicated on the hardware available for integration and test.

\subsubsection{Test Preparation and Configuration Overview}

Test Facility Configuration: PIST should be performed in an open area where the SV is cordoned off and power on testing can commence without disruption for an extended amount of time. PIST will be performed at ambient temperatures and pressure.

Unit Under Test Configuration: While a fully integrated SV is preferred, the SV may be configured with the minimum amount of subsystems for power on. This typically is the Command and Data Handling Subsystem (C\&DH) and Electrical Power Distribution Subsystem 
(EPDS), excluding the solar arrays. This will allow the initial testing of critical components prior to full SV integration. Next is the Communication Subsystem (Comm) to verify telemetry and commanding. From there, the SV is continually populated and tested.

Test Flow: Initial testing should include the verification of power on and off capability of the integrated components, starting with the EPDS and C\&DH, followed by their commanding and analysis of the telemetry signals. Additional subsystems when available should be brought online one at a time to limit unverified failures.

\subsection{Electromagnetic Interference / Compatibility Test (EMI/EMC)}

\subsubsection{Test Objective}

This test demonstrates that, under normal operating conditions, the system components do not have electromagnetic characteristics (emission and susceptibility) resulting in emissive, radiative or conductive interference. The objective is to test whether the hardware will operate properly if subjected to EMI from other sources or if hardware generates EMI which could hinder operations of other systems. This testing is typically performed prior to BIST to minimize the number of connector disconnects after the start of BIST. Test levels, limits, test points and susceptibility criteria shall be defined in component, subsystem and system specification, test procedures and reports.

\subsubsection{Test Preparations and Configuration Overview}

Test Facility Configuration: EMI / EMC testing should be done in an area or chamber which minimizes outside electromagnetic interference with minimal personnel. A faraday cage is an ideal example. Otherwise, the test should be performed in an open area away from any potential electromagnetic sources. EMI / EMC testing will be performed at ambient temperatures and pressure. 
Unit Under Test Configuration: The SV needs to be fully populated to verify all components, when integrated, do not show electromagnetic susceptibility to other components. This allows the discovery of components which emit electromagnetic interference which could impact other components or primary missions aboard the LV. The test configuration will vary based on the type of EMI being captured. For conductive, a more intrusive test is required tapping between each component's power cable and power interface. This detects conductive EMI through the power system. For radiative or emissive, the SV should be fully configured and assembled with detecting devices surrounding the SV. While the SV runs thought test segments turning on and off components, the external devices capture any radiated EMI which could affect the LV or primary mission.

Test Flow: The EMI / EMC test should first fully configure the vehicle for detection of electromagnetic signals. Then, the SV should turn on and command each component individually as a flight configured system to produce any potential component EMI / EMC. The SV can also run full system test segments to demonstrate mission capabilities. The commanding does not need to include all test segments of PIST, but should be robust enough to view the full range of mission CONOPS to view all EMI / EMC levels. Any analysis is then completed to verify the detected EMI does exceed established criteria or adversely impact the other components, SV or the LV.

\subsection{Baseline Integrated System Test (BIST)}

\subsubsection{Test Objectives}

The Baseline Integrated System Test (BIST) is performed to document baseline performance of the SV. BIST will functionally test all SV subsystems, demonstrate functionality of hardware and software and verify performance data to evaluate system operations. It will support performance analysis providing trend data and test primary and redundant equipment. The results of BIST will 
also be used for comparison with those of FIST, which is performed at the completion of the environmental tests. The data comparison between BIST and FIST is intended to demonstrate that the SV performance is acceptable after experiencing environments and handling. BIST begins the formal requirements verification process.

\subsubsection{Test Preparation and Configuration Overview}

Test Facility Configuration: BIST should be performed in an open area where the SV is cordoned off and power on testing can commence without disruption for an extended amount of time. BIST will be performed at ambient temperatures and pressure.

Unit Under Test Configuration: The SV must be fully integrated with flight components.

Test Flow: Testing should include the verification of power on and off capability of the integrated components, followed by their commanding and analysis of the telemetry signals. Subsystem testing should be performed serially to limit unverified failures.

\subsection{Acoustic Test}

\subsubsection{Test Objectives}

The acoustic test demonstrates the ability of the SV to endure acoustic acceptance test levels. This includes the random vibration, sinusoidal vibration and shock environments. The intent of the test is to demonstrate proper operation of the integrated flight hardware performance and workmanship when exposed to simulated ascent acoustic conditions. The acoustic test will detect material, process or workmanship defects that exist, as well as unanticipated equipment interface interactions that could result from stresses caused by heightened acoustic levels. The acoustic test is also used to validate the dynamic and stress analysis models. Acoustic test should be performed with a flight configured SV. All components that will be powered on during accent will be powered on during acoustic. 
In addition to the environmental testing, there is a post-acoustic functional test. The post-acoustic test includes a subset of tests from BIST designed to demonstrate the health of the SV after returning from acoustic testing.

\subsubsection{Test Preparation and Configuration Overview}

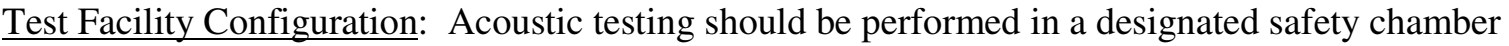
as this is where the SV will undergo accent level acoustic loading. Acoustic testing will be performed at ambient temperatures and pressure.

Unit Under Test Configuration: The SV must be fully integrated with flight components and have the proper safety precautions in place in the event a component is dislodged form the SV.

Test Flow: Acoustic loading should be applied one axis at a time. The acoustic loads are set to the predicted flight high extremes.

\subsection{Thermal Vacuum Test (TVAC)}

\subsubsection{Test Objectives}

The thermal vacuum (TVAC) testing demonstrates the ability to withstand the thermal stressing environment. It also detects material, process and workmanship defects that would response to thermal vacuum and thermal stress conditions.

A thermal balance test, or thermal cycle test, will be combined with the TVAC test for the first test article. A thermal balance test provides the data necessary to verify the analytical thermal model and demonstrates the ability of the vehicle thermal control subsystem to maintain specific component and subsystem temperatures limits for various operation scenarios throughout the entire vehicle. The TVAC test will verify proper end-to-end functional operation of all vehicle components and subsystems while being exposed to a cold and hot thermal vacuum environment. 
In addition to the environmental testing, there is a post-TVAC functional test. The post-TVAC test includes a subset of tests from BIST designed to demonstrate the health of the SV after returning the TVAC chamber to ambient temperature and pressure.

\subsubsection{Test Preparation and Configuration Overview}

Test Facility Configuration: This test must be accomplished in a thermal vacuum chamber.

Unit Under Test Configuration: The SV is populated with all flight hardware for this test. Prior to and during TVAC chamber pump down, the SV is powered on, in launch configuration, in order to best simulate the environmental condition experienced during an actual launch, ascent and on orbit operations.

Test Flow: The TVAC test consists of cold and hot cycles with verification testing. Environmentally, with the chamber pumped down to an absolute pressure (typically approximately $5 \times 10^{-5}$ ), the cold and hot environmental temperatures are set to predicted flight high and low extremes, consistent with component temperature constraints. The quantity of thermal cycles required is dependent on the program, but a general rule is a minimum of three (3). While stable at the hot and cold soak plateaus, the SV should undergo an end-to-end functional test to verify system performance at least once during a hot and cold plateau.

\subsection{Final Integrated System Test (FIST)}

\subsubsection{Test Objectives}

The Final Integrated System Test (FIST) is a comprehensive validation of the SV after the stressing tests of acoustic and TVAC. FIST is performed within the constraints of ambient conditions and repeats the testing performed during BIST. The data from the two tests are compared to demonstrated acceptable functionality of the system. FIST formally demonstrates and documents that all requirement have been verified. 


\subsubsection{Test Preparation and Configuration Overview}

Test Facility Configuration: FIST should be performed in an open area where the SV is cordoned off and power on testing can commence without disruption for an extended amount of time. FIST will be performed at ambient temperatures and pressure.

Unit Under Test Configuration: The SV must be fully integrated with flight components mimicking the configuration of BIST.

Test Flow: Testing should duplicate the testing in BIST to include the verification of power on and off capability of the integrated components, followed by their commanding and analysis of the telemetry signals. Subsystem testing should be performed serially to limit unverified failures. Testing in this phase will complete the verification of SV level test requirements.

\subsection{Final Mechanical Deploys}

\subsubsection{Test Objectives}

Final Mechanical Deploys are performed at the end of FIST to obtain verification and acceptance of all mechanical deployable component operability. After this phase all deployable components are stowed in their flight configuration. In the event there are no mechanisms which deploy, this phase may be omitted. It is advised that all mechanical deploys be demonstrated prior to the final requirement verification completed in this phase.

\subsubsection{Test Preparation and Configuration Overview}

Test Facility Configuration: Final Mechanical Deploys should be performed in an open area where the SV is cordoned off and where deployments can commence without disruption or potential impact to the surroundings or personnel. 
Unit Under Test Configuration: The SV must be fully integrated with flight components mimicking the configuration of FIST.

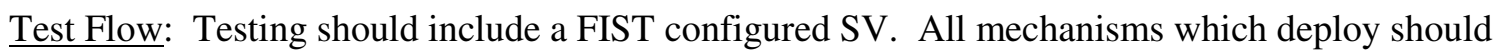
be tested one at a time to achieve their flight configurations.

\subsection{Factory Confidence Test (FCT)}

\subsubsection{Test Objectives}

The Factory Confidence Test (FCT) is performed to obtain a baseline of SV performance before shipping to the launch base. It is an abbreviated integrated system test the results of which will be compared with those from the Launch Base Confidence Test (LBCT) to show that there was no damage suffered in shipment and handling between the factory and the launch base. This is especially important for SVs that have undergone storage. If the time between the completion of FIST and final mechanical deploys and shipment to the launch base is minimal, FCT and LBCT can be omitted.

\subsubsection{Test Preparation and Configuration Overview}

Test Facility Configuration: FCT should be performed in an open area where the SV is cordoned off and power on testing can commence without disruption for an extended amount of time.

Unit Under Test Configuration: The SV must be fully integrated with flight components mimicking the configuration of FIST.

Test Flow: Testing should include an abbreviated version of the FIST tests to include power on and off capability, commanding, telemetry transmission and critical alignments measurements. Subsystem testing should be performed serially to limit unverified failures. 


\subsection{Launch Base Confidence Test (LBCT)}

\subsubsection{Test Objectives}

The Launch Base Confidence Test (LBCT) is performed to obtain an assessment of SV performance after shipping to the launch base. It is an abbreviated integrated system test and identical to the FCT the results of which will be compared with those from the FCT to show there was no damage suffered in shipment and handing between the factory and the launch base. If the time between the completion of FIST and final mechanical deploys and shipment to the launch base is minimal, FCT and LBCT can be omitted.

\subsubsection{Test Preparation and Configuration Overview}

Test Facility Configuration: LBCT should be performed in an open SV processing facility where the SV is cordoned off and power on testing can commence without disruption for an extended amount of time.

Unit Under Test Configuration: The SV must be fully integrated with flight components mimicking the configuration of FCT.

Test Flow: Testing should duplicate the testing performed in FCT to include power on and off capability, commanding, telemetry transmission and critical alignments measurements. Subsystem testing should be performed serially to limit unverified failures.

\subsection{Fueling and Encapsulation}

\subsubsection{Test Objectives}

Perform final SV fueling and encapsulation into the PPOD and LV. As propellants are currently not allowed on SVs this phases speaks specifically to encapsulation. Encapsulation is done by the PPOD integrator with SV personnel support and includes the acceptance testing. Acceptance testing by the PPOD integrator is defined in Section 3.6 of the CDS. 


\subsubsection{Test Preparation and Configuration Overview}

A flight configured SV ready for launch. SV personnel support should be provided to the PPOD integrator during encapsulation and final acceptance testing.

\subsection{Post Mate Tests}

\subsubsection{Test Objectives}

The Post Mate Test performs final diagnostic or data analysis tasks prior to launch. This includes full battery charge and discharge if it has not been done in a prior phase.

\subsubsection{Test Preparation and Configuration Overview}

A flight configured SV ready for launch. Access to the umbilical connector ports may be available once integrated into the PPOD. 


\section{Applicable Documents}

Below details the document versions used in the TRD.

\begin{tabular}{|l|l|}
\hline \multicolumn{1}{|c|}{ Document } & \multicolumn{1}{c|}{ Document Title } \\
\hline CDS & CubeSat Design Specification, Revision 12, 2009 \\
\hline GSFC-STD-7000 & $\begin{array}{l}\text { General Environmental Verification Standard (GEVS) for GSFC } \\
\text { Flight Program and Projects, 1996 }\end{array}$ \\
\hline INCOSE-TP-2003-002-03 & Systems Engineering Handbook, Volume 3, 2006 \\
\hline LSP-REQ-317.01 & $\begin{array}{l}\text { Program Level Poly Picosatellite Orbital Deployer (PPOD) and } \\
\text { CubeSat Requirements Document by the Launch Services } \\
\text { Program, Revision Basic, 2009 }\end{array}$ \\
\hline MIL-STD-1540D & $\begin{array}{l}\text { Department of Defense Standard Practice, Product Verification } \\
\text { Requirements for Launch, Upper Stage, and Space Vehicles, 1999 }\end{array}$ \\
\hline
\end{tabular}




\section{System Test Requirements}

The following sections identify the system test requirements, segregated by subsystem, for the $\mathrm{SV}$. The test requirements are further segregated by component to assist in the definition of any retest requirements that would be necessary as a result of component removals for rework, redesign, troubleshooting, etc. An example of an SV configuration is illustrated in Figure A3 and A4. Figure A3 will be used as a general architecture for the system level test requirements.

The requirements assume redundancy in the solar arrays, temperature sensors and magnetometers due to the duplication of components populating the side boards. Batteries have true redundancy using two in parallel. No other components or subsystems are assumed to have redundancy. Component or subsystem requirements should be added for pico-satellite architecture with additional redundancy. An example would be using as redundant Comm Subsystem. All Comm Subsystem requirements would be duplicated to account for the primary and secondary subsystem. Additionally, there would need to be requirements added to verify the immediate switch from primary to secondary Comm Subsystem in the event of a failure.

As most pico-satellites consist of few parts, the C\&DH typically only consists of one motherboard with inputs and outputs to all other pico-satellite subsystem making it the central interface. As such, the motherboard (or C\&DH subsystem) will be referenced as the System Board.

Each requirement is assigned unique requirement identifier, or REQID, to provide traceability from the higher level specifications to the applicable test segment/procedure that verified the test requirements. REQIDs will be a six (6) digit alpha-numeric unique code. The first three (3) characters denote the subsystem (e.g. Electrical Power Distribution Subsystem is EPS) and the last three characters form a unique number, preferably in ascending order from the first test 
requirement. An example of the first and tenth test requirement for the EPDS would be EPS001 and EPS 010, respectively.

The following section also provides the test phase(s) in which each requirement is to be verified. Table A2 depicts the traceability between the stakeholder specification requirements which are to be verified under test and the associated TRD REQID.

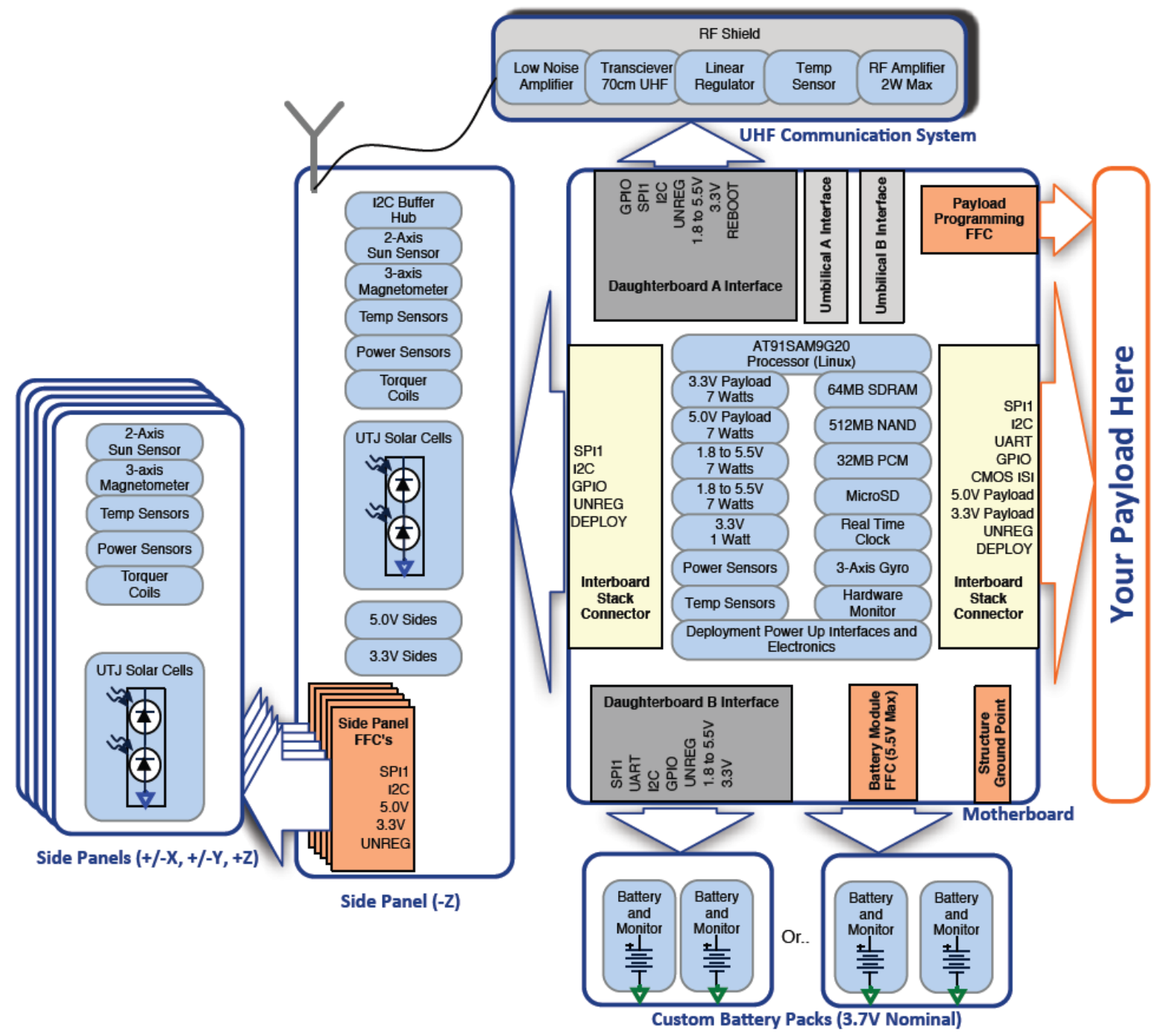

Figure A3: CubeSat System Diagram Example

Figure courtesy of the Cal Poly PolySat Program 


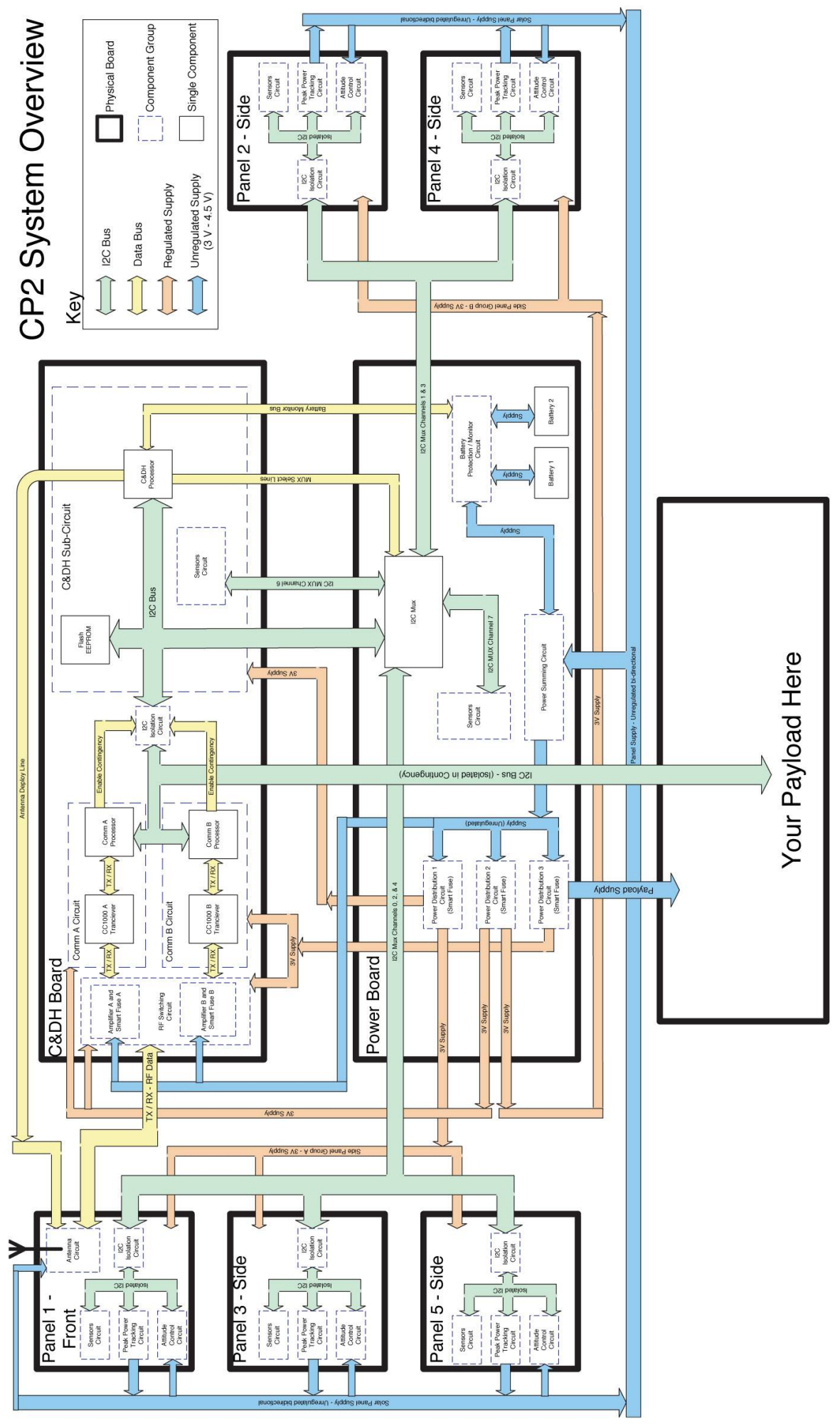

Figure A4: CubeSat Bus Example

Figure courtesy of the Cal Poly PolySat Program 


\begin{tabular}{|l|l|l|}
\hline \multicolumn{3}{|c|}{ Table A2: Test Requirement to REQID Traceability } \\
\hline Specification & Section Number & \multicolumn{1}{c|}{ REQID } \\
\hline \multirow{5}{*}{} & 2.1 .2 & STR001, STR002 \\
\cline { 2 - 3 } & 2.1 .7 .1 & TCS001 \\
\cline { 2 - 3 } & 2.1 .7 .2 & TCS001 \\
\cline { 2 - 3 } & 2.2 .10 & STR008 \\
\cline { 2 - 3 } & 2.2 .15 & STR003 \\
\cline { 2 - 3 } & 2.2 .16 & STR004 \\
\cline { 2 - 3 } & 2.2 .17 & STR005 \\
\cline { 2 - 3 } & 2.2 .21 & STR006 \\
\cline { 2 - 3 } & 2.2 .21 .2 & STR007 \\
\cline { 2 - 3 } & 2.4 .1 & COM048 \\
\cline { 2 - 3 } & 2.4 .2 & CDH069, STR009 \\
\cline { 2 - 3 } & 2.4 .3 & COM049, CDH070 \\
\cline { 2 - 3 } & 3.1 & STR002 \\
\cline { 2 - 3 } & 3.2 & TCS001 \\
\cline { 2 - 3 } & 3.5 & STR001, STR002, TCS001 \\
\hline \multirow{5}{*}{ CRD } & 6.2 .1 & STR001, STR002, TCS001 \\
\cline { 2 - 3 } & 6.2 .2 & STR001 \\
\cline { 2 - 3 } & 6.2 .10 & COM049, CDH070 \\
\cline { 2 - 3 } & 6.2 .11 .1 & \\
\hline
\end{tabular}




\subsection{Attitude Control Subsystem (ACS) Test Requirements}

The ACS provides the attitude control, station keeping and orientation capability during all phases of the mission starting at spacecraft separation from the launch vehicle and throughout its operational lifetime.

Table A3 lists the ACS capabilities being tested.

\begin{tabular}{|c|c|c|}
\hline \multicolumn{3}{|c|}{ Table A3: ACS Test Summary } \\
\hline Section & Section Title & Capability Being Tested \\
\hline 8.1 .1 & Magnetometer & $\begin{array}{l}\text { Verify power is supplied } \\
\text { Verify measurement of earth magnetic field } \\
\text { Verify correlation of readings } \\
\text { Verify polarity } \\
\text { Verify signal transmission } \\
\text { Verify state entrance }\end{array}$ \\
\hline 8.1 .2 & Magneto Torque Coils & $\begin{array}{l}\text { Verify power is supplied } \\
\text { Verify torque direction } \\
\text { Verify correlation of readings } \\
\text { Verify polarity } \\
\text { Verify signal transmission } \\
\text { Verify state entrance }\end{array}$ \\
\hline 8.1 .3 & Rate Sensor Gyroscope & $\begin{array}{l}\text { Verify power is supplied } \\
\text { Verify rate measurement } \\
\text { Verify signal transmission } \\
\text { Verify state entrance }\end{array}$ \\
\hline 8.1 .4 & Sun Sensors & $\begin{array}{l}\text { Verify power is supplied } \\
\text { Verify signal transmission }\end{array}$ \\
\hline
\end{tabular}




\subsubsection{Magnetometer Test Requirements}

\begin{tabular}{|c|c|c|c|c|c|c|c|c|c|c|c|c|}
\hline \multirow{2}{*}{ Magnetometer Test Requirement } & \multicolumn{12}{|c|}{ Phase } \\
\hline & 1 & 2 & 3 & 4 & 5 & 6 & 7 & 8 & 9 & 10 & 11 & 12 \\
\hline (ACS001) Verify the System Board supplies power to the $-Y$ magnetometer. & & $\mathrm{X}$ & $\mathrm{X}$ & $\mathrm{X}$ & & $\mathrm{X}$ & $\mathrm{X}$ & & $\mathrm{X}$ & $\mathrm{X}$ & & \\
\hline (ACS002) Verify the System Board supplies power to the $+Y$ magnetometer. & & $\mathrm{X}$ & $\mathrm{X}$ & $\mathrm{X}$ & & $\mathrm{X}$ & $\mathrm{X}$ & & $\mathrm{X}$ & $\mathrm{X}$ & & \\
\hline (ACS003) Verify the System Board supplies power to the $-\mathrm{X}$ magnetometer. & & $\mathrm{X}$ & $\mathrm{X}$ & $\mathrm{X}$ & & $\mathrm{X}$ & $X$ & & $\mathrm{X}$ & $\mathrm{X}$ & & \\
\hline (ACS004) Verify the System Board supplies power to the $+\mathrm{X}$ magnetometer. & & $\mathrm{X}$ & $\mathrm{X}$ & $\mathrm{X}$ & & $\mathrm{X}$ & $\mathrm{X}$ & & $\mathrm{X}$ & $\mathrm{X}$ & & \\
\hline (ACS005) Verify the System Board supplies power to the $-\mathrm{Z}$ magnetometer. & & $\mathrm{X}$ & $X$ & $X$ & & $\mathrm{X}$ & $\mathrm{X}$ & & $\mathrm{X}$ & $\mathrm{X}$ & & \\
\hline (ACS006) Verify the System Board supplies power to the $+Z$ magnetometer. & & $\mathrm{X}$ & $X$ & $\mathrm{X}$ & & $\mathrm{X}$ & $\mathrm{X}$ & & $\mathrm{X}$ & $X$ & & \\
\hline $\begin{array}{l}\text { (ACS007) Verify via telemetry the System Board capability to enable }-Y \\
\text { Magnetometer power. }\end{array}$ & & $X$ & & $X$ & & $X$ & $X$ & & $X$ & $X$ & & \\
\hline $\begin{array}{l}\text { (ACS008) Verify via telemetry the System Board capability to enable }+Y \\
\text { Magnetometer power. }\end{array}$ & & $X$ & & $X$ & & $X$ & $X$ & & $X$ & $X$ & & \\
\hline $\begin{array}{l}\text { (ACS009) Verify via telemetry the System Board capability to enable }-X \\
\text { Magnetometer power. }\end{array}$ & & $X$ & & $X$ & & $X$ & $X$ & & $X$ & $X$ & & \\
\hline $\begin{array}{l}\text { (ACS010) Verify via telemetry the System Board capability to enable }+X \\
\text { Magnetometer power. }\end{array}$ & & $X$ & & $X$ & & $X$ & $X$ & & $X$ & $X$ & & \\
\hline $\begin{array}{l}\text { (ACS011) Verify via telemetry the System Board capability to enable }-Z \\
\text { Magnetometer power. }\end{array}$ & & $\mathrm{X}$ & & $X$ & & $X$ & $\mathrm{X}$ & & $X$ & $X$ & & \\
\hline
\end{tabular}




\begin{tabular}{|c|c|c|c|c|c|c|c|c|c|c|c|c|}
\hline \multirow{2}{*}{ Magnetometer Test Requirement } & \multicolumn{12}{|c|}{ Phase } \\
\hline & $\mathbf{1}$ & 2 & 3 & 4 & 5 & 6 & 7 & 8 & 9 & 10 & 11 & 12 \\
\hline $\begin{array}{l}\text { (ACS012) Verify via telemetry the System Board capability to enable }+Z \\
\text { Magnetometer power. }\end{array}$ & & $\mathrm{X}$ & & $\mathrm{X}$ & & $\mathrm{X}$ & $\mathrm{X}$ & & $\mathrm{X}$ & $\mathrm{X}$ & & \\
\hline $\begin{array}{l}\text { (ACS013) Verify via telemetry the System Board capability to disable the }-\mathrm{Y} \\
\text { Magnetometer power. }\end{array}$ & & $\mathrm{X}$ & & $\mathrm{X}$ & & $\mathrm{X}$ & $\mathrm{X}$ & & $\mathrm{X}$ & $\mathrm{X}$ & & \\
\hline $\begin{array}{l}\text { (ACS014) Verify via telemetry the System Board capability to disable the }+Y \\
\text { Magnetometer power. }\end{array}$ & & $\mathrm{X}$ & & $\mathrm{X}$ & & $\mathrm{X}$ & $\mathrm{X}$ & & $\mathrm{X}$ & $\mathrm{X}$ & & \\
\hline $\begin{array}{l}\text { (ACS015) Verify via telemetry the System Board capability to disable the }-X \\
\text { Magnetometer power. }\end{array}$ & & $\mathrm{X}$ & & $\mathrm{X}$ & & $\mathrm{X}$ & $\mathrm{X}$ & & $\mathrm{X}$ & $\mathrm{X}$ & & \\
\hline $\begin{array}{l}\text { (ACS016) Verify via telemetry the System Board capability to disable the }+X \\
\text { Magnetometer power. }\end{array}$ & & $\mathrm{X}$ & & $\mathrm{X}$ & & $\mathrm{X}$ & $\mathrm{X}$ & & $\mathrm{X}$ & $\mathrm{X}$ & & \\
\hline $\begin{array}{l}\text { (ACS017) Verify via telemetry the System Board capability to disable the }-\mathrm{Z} \\
\text { Magnetometer power. }\end{array}$ & & $\mathrm{X}$ & & $\mathrm{X}$ & & $\mathrm{X}$ & $\mathrm{X}$ & & $\mathrm{X}$ & $\mathrm{X}$ & & \\
\hline $\begin{array}{l}\text { (ACS018) Verify via telemetry the System Board capability to disable the }+Z \\
\text { Magnetometer power. }\end{array}$ & & $\mathrm{X}$ & & $\mathrm{X}$ & & $\mathrm{X}$ & $\mathrm{X}$ & & $\mathrm{X}$ & $\mathrm{X}$ & & \\
\hline $\begin{array}{l}\text { (ACS019) Verify the -Y Magnetometer standby state is initiated via digital command } \\
\text { from the System Board. }\end{array}$ & & & & $\mathrm{X}$ & & $\mathrm{X}$ & $\mathrm{X}$ & & $\mathrm{X}$ & $\mathrm{X}$ & & \\
\hline $\begin{array}{l}\text { (ACSO20) Verify the }+ \text { Y Magnetometer standby state is initiated via digital command } \\
\text { from the System Board. }\end{array}$ & & & & $\mathrm{X}$ & & $X$ & $X$ & & $X$ & $X$ & & \\
\hline
\end{tabular}




\begin{tabular}{|c|c|c|c|c|c|c|c|c|c|c|c|c|}
\hline \multirow{2}{*}{ Magnetometer Test Requirement } & \multicolumn{12}{|c|}{ Phase } \\
\hline & 1 & 2 & 3 & 4 & 5 & 6 & 7 & 8 & 9 & 10 & 11 & 12 \\
\hline $\begin{array}{l}\text { (ACS021) Verify the }-X \text { Magnetometer standby state is initiated via digital command } \\
\text { from the System Board. }\end{array}$ & & & & $\mathrm{X}$ & & $\mathrm{X}$ & $X$ & & $\mathrm{X}$ & $\mathrm{X}$ & & \\
\hline $\begin{array}{l}\text { (ACS022) Verify the }+X \text { Magnetometer standby state is initiated via digital command } \\
\text { from the System Board. }\end{array}$ & & & & $X$ & & $\mathrm{X}$ & $X$ & & $\mathrm{X}$ & $\mathrm{X}$ & & \\
\hline $\begin{array}{l}\text { (ACS023) Verify the }-\mathrm{Z} \text { Magnetometer standby state is initiated via digital command } \\
\text { from the System Board. }\end{array}$ & & & & $\mathrm{X}$ & & $\mathrm{X}$ & $\mathrm{X}$ & & $\mathrm{X}$ & $\mathrm{X}$ & & \\
\hline $\begin{array}{l}\text { (ACS024) Verify the }+Z \text { Magnetometer standby state is initiated via digital command } \\
\text { from the System Board. }\end{array}$ & & & & $\mathrm{X}$ & & $\mathrm{X}$ & $\mathrm{X}$ & & $\mathrm{X}$ & $\mathrm{X}$ & & \\
\hline $\begin{array}{l}\text { (ACS025) Verify the -Y Magnetometer nominal state is initiated via digital command } \\
\text { from the System Board. }\end{array}$ & & & & $\mathrm{X}$ & & $\mathrm{X}$ & $\mathrm{X}$ & & $\mathrm{X}$ & $\mathrm{X}$ & & \\
\hline $\begin{array}{l}\text { (ACS026) Verify the }+ \text { Y Magnetometer nominal state is initiated via digital command } \\
\text { from the System Board. }\end{array}$ & & & & $\mathrm{X}$ & & $\mathrm{X}$ & $\mathrm{X}$ & & $\mathrm{X}$ & $\mathrm{X}$ & & \\
\hline $\begin{array}{l}\text { (ACS027) Verify the }-X \text { Magnetometer nominal state is initiated via digital command } \\
\text { from the System Board. }\end{array}$ & & & & $\mathrm{X}$ & & $X$ & $\mathrm{X}$ & & $\mathrm{X}$ & $\mathrm{X}$ & & \\
\hline $\begin{array}{l}\text { (ACS028) Verify the }+X \text { Magnetometer nominal state is initiated via digital command } \\
\text { from the System Board. }\end{array}$ & & & & $\mathrm{X}$ & & $X$ & $\mathrm{X}$ & & $\mathrm{X}$ & $\mathrm{X}$ & & \\
\hline $\begin{array}{l}\text { (ACS029) Verify the -Z Magnetometer nominal state is initiated via digital command } \\
\text { from the System Board. }\end{array}$ & & & & $\mathrm{X}$ & & $\mathrm{X}$ & $\mathrm{X}$ & & $\mathrm{X}$ & $\mathrm{X}$ & & \\
\hline
\end{tabular}




\begin{tabular}{|c|c|c|c|c|c|c|c|c|c|c|c|c|}
\hline \multirow{2}{*}{ Magnetometer Test Requirement } & \multicolumn{12}{|c|}{ Phase } \\
\hline & 1 & 2 & 3 & 4 & 5 & 6 & 7 & 8 & 9 & 10 & 11 & 12 \\
\hline $\begin{array}{l}\text { (ACS030) Verify the }+Z \text { Magnetometer nominal state is initiated via digital command } \\
\text { from the System Board. }\end{array}$ & & & & $\mathrm{X}$ & & $\mathrm{X}$ & $X$ & & $\mathrm{X}$ & $\mathrm{X}$ & & \\
\hline $\begin{array}{l}\text { (ACS031) Verify the -Y Magnetometer provides telemetry after System Board digital } \\
\text { sample command or power on. }\end{array}$ & & & & $\mathrm{X}$ & & $\mathrm{X}$ & $X$ & & $\mathrm{X}$ & $\mathrm{X}$ & & \\
\hline $\begin{array}{l}\text { (ACS032) Verify the }+ \text { Y Magnetometer provides telemetry after System Board digital } \\
\text { sample command or power on. }\end{array}$ & & & & $\mathrm{X}$ & & $\mathrm{X}$ & $\mathrm{X}$ & & $\mathrm{X}$ & $\mathrm{X}$ & & \\
\hline $\begin{array}{l}\text { (ACS033) Verify the -X Magnetometer provides telemetry after System Board digital } \\
\text { sample command or power on. }\end{array}$ & & & & $\mathrm{X}$ & & $\mathrm{X}$ & $\mathrm{X}$ & & $\mathrm{X}$ & $\mathrm{X}$ & & \\
\hline $\begin{array}{l}\text { (ACS034) Verify the }+X \text { Magnetometer provides telemetry after System Board digital } \\
\text { sample command or power on. }\end{array}$ & & & & $\mathrm{X}$ & & $\mathrm{X}$ & $\mathrm{X}$ & & $\mathrm{X}$ & $\mathrm{X}$ & & \\
\hline $\begin{array}{l}\text { (ACS035) Verify the -Z Magnetometer provides telemetry after System Board digital } \\
\text { sample command or power on. }\end{array}$ & & & & $\mathrm{X}$ & & $\mathrm{X}$ & $\mathrm{X}$ & & $\mathrm{X}$ & $\mathrm{X}$ & & \\
\hline $\begin{array}{l}\text { (ACS036) Verify the }+Z \text { Magnetometer provides telemetry after System Board digital } \\
\text { sample command or power on. }\end{array}$ & & & & $\mathrm{X}$ & & $X$ & $\mathrm{X}$ & & $\mathrm{X}$ & $\mathrm{X}$ & & \\
\hline $\begin{array}{l}\text { (ACS037) Verify the polarity of the }-\mathrm{Y} \text { magnetometer output from telemetry as } \\
\text { compared to a known source. }\end{array}$ & & & & $\mathrm{X}$ & & & $\mathrm{X}$ & & & & & \\
\hline $\begin{array}{l}\text { (ACS038) Verify the polarity of the }+ \text { Y magnetometer output from telemetry as } \\
\text { compared to a known source. }\end{array}$ & & & & $\mathrm{X}$ & & & $\mathrm{X}$ & & & & & \\
\hline
\end{tabular}




\begin{tabular}{|c|c|c|c|c|c|c|c|c|c|c|c|c|}
\hline \multirow{2}{*}{ Magnetometer Test Requirement } & \multicolumn{12}{|c|}{ Phase } \\
\hline & 1 & 2 & 3 & 4 & 5 & 6 & 7 & 8 & 9 & 10 & 11 & 12 \\
\hline $\begin{array}{l}\text { (ACS039) Verify the polarity of the }-\mathrm{X} \text { magnetometer output from telemetry as } \\
\text { compared to a known source. }\end{array}$ & & & & $\mathrm{X}$ & & & $\mathrm{X}$ & & & & & \\
\hline $\begin{array}{l}\text { (ACS040) Verify the polarity of the }+\mathrm{X} \text { magnetometer output from telemetry as } \\
\text { compared to a known source. }\end{array}$ & & & & $\mathrm{X}$ & & & $\mathrm{X}$ & & & & & \\
\hline $\begin{array}{l}\text { (ACS041) Verify the polarity of the }-\mathrm{Z} \text { magnetometer output from telemetry as } \\
\text { compared to a known source. }\end{array}$ & & & & $\mathrm{X}$ & & & $\mathrm{X}$ & & & & & \\
\hline $\begin{array}{l}\text { (ACS042) Verify the polarity of the }+\mathrm{Z} \text { magnetometer output from telemetry as } \\
\text { compared to a known source. }\end{array}$ & & & & $\mathrm{X}$ & & & $\mathrm{X}$ & & & & & \\
\hline $\begin{array}{l}\text { (ACS043) Verify that all magnetometer magnetic field intensity telemetry values are } \\
\text { within a minimum of } 10 \% \text { of each other. }\end{array}$ & & $\mathrm{X}$ & & $\mathrm{X}$ & & $\mathrm{X}$ & $\mathrm{X}$ & & $\mathrm{X}$ & $\mathrm{X}$ & & \\
\hline
\end{tabular}

\subsubsection{Magneto Torque Coil Test Requirements}




\begin{tabular}{|c|c|c|c|c|c|c|c|c|c|c|c|c|}
\hline \multirow{2}{*}{ Magneto Torque Coil Test Requirement } & \multicolumn{12}{|c|}{ Phase } \\
\hline & 1 & 2 & 3 & 4 & 5 & 6 & 7 & 8 & 9 & 10 & 11 & 12 \\
\hline (ACS044) Verify the System Board supplies power to the $-Y$ magneto torque coil. & & $\mathrm{X}$ & $\mathrm{X}$ & $\mathrm{X}$ & & $\mathrm{X}$ & $\mathrm{X}$ & & $\mathrm{X}$ & $\mathrm{X}$ & & \\
\hline (ACS045) Verify the System Board supplies power to the $+Y$ magneto torque coil. & & $\mathrm{X}$ & $\mathrm{X}$ & $\mathrm{X}$ & & $X$ & $X$ & & $\mathrm{X}$ & $\mathrm{X}$ & & \\
\hline (ACS046) Verify the System Board supplies power to the $-\mathrm{X}$ magneto torque coil. & & $\mathrm{X}$ & $\mathrm{X}$ & $\mathrm{X}$ & & $\mathrm{X}$ & $\mathrm{X}$ & & $\mathrm{X}$ & $\mathrm{X}$ & & \\
\hline (ACS047) Verify the System Board supplies power to the $+X$ magneto torque coil. & & $\mathrm{X}$ & $\mathrm{X}$ & $\mathrm{X}$ & & $\mathrm{X}$ & $\mathrm{X}$ & & $\mathrm{X}$ & $\mathrm{X}$ & & \\
\hline (ACS048) Verify the System Board supplies power to the $-\mathrm{Z}$ magneto torque coil. & & $\mathrm{X}$ & $\mathrm{X}$ & $\mathrm{X}$ & & $\mathrm{X}$ & $\mathrm{X}$ & & $\mathrm{X}$ & $\mathrm{X}$ & & \\
\hline (ACS049) Verify the System Board supplies power to the $+Z$ magneto torque coil. & & $\mathrm{X}$ & $\mathrm{X}$ & $\mathrm{X}$ & & $\mathrm{X}$ & $X$ & & $X$ & $X$ & & \\
\hline $\begin{array}{l}\text { (ACS050) Verify via telemetry the System Board capability to enable }- \text { Y magneto } \\
\text { torque coil power. }\end{array}$ & & $X$ & & $X$ & & $X$ & $X$ & & $X$ & $X$ & & \\
\hline $\begin{array}{l}\text { (ACS051) Verify via telemetry the System Board capability to enable }+ \text { Y magneto } \\
\text { torque coil power. }\end{array}$ & & $X$ & & $X$ & & $X$ & $X$ & & $X$ & $X$ & & \\
\hline $\begin{array}{l}\text { (ACS052) Verify via telemetry the System Board capability to enable }-\mathrm{X} \text { magneto } \\
\text { torque coil power. }\end{array}$ & & $X$ & & $X$ & & $X$ & $X$ & & $X$ & $X$ & & \\
\hline $\begin{array}{l}\text { (ACS053) Verify via telemetry the System Board capability to enable }+X \text { magneto } \\
\text { torque coil power. }\end{array}$ & & $X$ & & $X$ & & $X$ & $X$ & & $X$ & $X$ & & \\
\hline $\begin{array}{l}\text { (ACS054) Verify via telemetry the System Board capability to enable }-\mathrm{Z} \text { magneto } \\
\text { torque coil power. }\end{array}$ & & $X$ & & $X$ & & $X$ & $X$ & & $X$ & $X$ & & \\
\hline
\end{tabular}




\begin{tabular}{|c|c|c|c|c|c|c|c|c|c|c|c|c|}
\hline \multirow{2}{*}{ Magneto Torque Coil Test Requirement } & \multicolumn{12}{|c|}{ Phase } \\
\hline & $\mathbf{1}$ & 2 & 3 & 4 & 5 & 6 & 7 & 8 & 9 & 10 & 11 & 12 \\
\hline $\begin{array}{l}\text { (ACS055) Verify via telemetry the System Board capability to enable }+Z \text { magneto } \\
\text { torque coil power. }\end{array}$ & & $\mathrm{X}$ & & $\mathrm{X}$ & & $\mathrm{X}$ & $\mathrm{X}$ & & $\mathrm{X}$ & $\mathrm{X}$ & & \\
\hline $\begin{array}{l}\text { (ACS056) Verify via telemetry the System Board capability to disable the }-\mathrm{Y} \text { magneto } \\
\text { torque coil power. }\end{array}$ & & $\mathrm{X}$ & & $\mathrm{X}$ & & $\mathrm{X}$ & $\mathrm{X}$ & & $\mathrm{X}$ & $\mathrm{X}$ & & \\
\hline $\begin{array}{l}\text { (ACS057) Verify via telemetry the System Board capability to disable the }+Y \text { magneto } \\
\text { torque coil power. }\end{array}$ & & $\mathrm{X}$ & & $\mathrm{X}$ & & $\mathrm{X}$ & $\mathrm{X}$ & & $\mathrm{X}$ & $\mathrm{X}$ & & \\
\hline $\begin{array}{l}\text { (ACS058) Verify via telemetry the System Board capability to disable the }-\mathrm{X} \text { magneto } \\
\text { torque coil power. }\end{array}$ & & $\mathrm{X}$ & & $\mathrm{X}$ & & $\mathrm{X}$ & $\mathrm{X}$ & & $\mathrm{X}$ & $\mathrm{X}$ & & \\
\hline $\begin{array}{l}\text { (ACS059) Verify via telemetry the System Board capability to disable the }+\mathrm{X} \text { magneto } \\
\text { torque coil power. }\end{array}$ & & $\mathrm{X}$ & & $\mathrm{X}$ & & $\mathrm{X}$ & $\mathrm{X}$ & & $\mathrm{X}$ & $\mathrm{X}$ & & \\
\hline $\begin{array}{l}\text { (ACS060) Verify via telemetry the System Board capability to disable the }-\mathrm{Z} \text { magneto } \\
\text { torque coil power. }\end{array}$ & & $\mathrm{X}$ & & $\mathrm{X}$ & & $\mathrm{X}$ & $\mathrm{X}$ & & $\mathrm{X}$ & $\mathrm{X}$ & & \\
\hline $\begin{array}{l}\text { (ACS061) Verify via telemetry the System Board capability to disable the }+\mathrm{Z} \text { magneto } \\
\text { torque coil power. }\end{array}$ & & $X$ & & $X$ & & $X$ & $X$ & & $X$ & $X$ & & \\
\hline $\begin{array}{l}\text { (ACS062) Verify the }-\mathrm{Y} \text { magneto torque coil standby state is initiated via digital } \\
\text { command from the System Board. }\end{array}$ & & $X$ & & $X$ & & $X$ & $X$ & & $X$ & $X$ & & \\
\hline $\begin{array}{l}\text { (ACS063) Verify the }+Y \text { magneto torque coil standby state is initiated via digital } \\
\text { command from the System Board. }\end{array}$ & & $X$ & & $X$ & & $X$ & $X$ & & $X$ & $X$ & & \\
\hline
\end{tabular}




\begin{tabular}{|c|c|c|c|c|c|c|c|c|c|c|c|c|}
\hline \multirow{2}{*}{ Magneto Torque Coil Test Requirement } & \multicolumn{12}{|c|}{ Phase } \\
\hline & $\mathbf{1}$ & 2 & 3 & 4 & 5 & 6 & 7 & 8 & 9 & 10 & 11 & 12 \\
\hline $\begin{array}{l}\text { (ACS064) Verify the }-\mathrm{X} \text { magneto torque coil standby state is initiated via digital } \\
\text { command from the System Board. }\end{array}$ & & $\mathrm{X}$ & & $\mathrm{X}$ & & $\mathrm{X}$ & $\mathrm{X}$ & & $\mathrm{X}$ & $\mathrm{X}$ & & \\
\hline $\begin{array}{l}\text { (ACS065) Verify the }+\mathrm{X} \text { magneto torque coil standby state is initiated via digital } \\
\text { command from the System Board. }\end{array}$ & & $\mathrm{X}$ & & $\mathrm{X}$ & & $\mathrm{X}$ & $\mathrm{X}$ & & $\mathrm{X}$ & $\mathrm{X}$ & & \\
\hline $\begin{array}{l}\text { (ACS066) Verify the }-\mathrm{Z} \text { magneto torque coil standby state is initiated via digital } \\
\text { command from the System Board. }\end{array}$ & & $\mathrm{X}$ & & $\mathrm{X}$ & & $\mathrm{X}$ & $\mathrm{X}$ & & $\mathrm{X}$ & $\mathrm{X}$ & & \\
\hline $\begin{array}{l}\text { (ACS067) Verify the }+Z \text { magneto torque coil standby state is initiated via digital } \\
\text { command from the System Board. }\end{array}$ & & $\mathrm{X}$ & & $\mathrm{X}$ & & $\mathrm{X}$ & $\mathrm{X}$ & & $\mathrm{X}$ & $\mathrm{X}$ & & \\
\hline $\begin{array}{l}\text { (ACS068) Verify the }-Y \text { magneto torque coil nominal state is initiated via digital } \\
\text { command from the System Board. }\end{array}$ & & $\mathrm{X}$ & & $\mathrm{X}$ & & $\mathrm{X}$ & $\mathrm{X}$ & & $\mathrm{X}$ & $\mathrm{X}$ & & \\
\hline $\begin{array}{l}\text { (ACS069) Verify the }+Y \text { magneto torque coil nominal state is initiated via digital } \\
\text { command from the System Board. }\end{array}$ & & $\mathrm{X}$ & & $\mathrm{X}$ & & $\mathrm{X}$ & $\mathrm{X}$ & & $\mathrm{X}$ & $X$ & & \\
\hline $\begin{array}{l}\text { (ACS070) Verify the }-X \text { magneto torque coil nominal state is initiated via digital } \\
\text { command from the System Board. }\end{array}$ & & $X$ & & $X$ & & $X$ & $X$ & & $X$ & $X$ & & \\
\hline $\begin{array}{l}\text { (ACS071) Verify the }+\mathrm{X} \text { magneto torque coil nominal state is initiated via digital } \\
\text { command from the System Board. }\end{array}$ & & $X$ & & $X$ & & $X$ & $X$ & & $X$ & $X$ & & \\
\hline $\begin{array}{l}\text { (ACS072) Verify the }-\mathrm{Z} \text { magneto torque coil nominal state is initiated via digital } \\
\text { command from the System Board. }\end{array}$ & & $X$ & & $X$ & & $X$ & $X$ & & $X$ & $X$ & & \\
\hline
\end{tabular}




\begin{tabular}{|c|c|c|c|c|c|c|c|c|c|c|c|c|}
\hline \multirow{2}{*}{ Magneto Torque Coil Test Requirement } & \multicolumn{12}{|c|}{ Phase } \\
\hline & 1 & 2 & 3 & 4 & 5 & 6 & 7 & 8 & 9 & 10 & 11 & 12 \\
\hline $\begin{array}{l}\text { (ACS073) Verify the }+Z \text { magneto torque coil nominal state is initiated via digital } \\
\text { command from the System Board. }\end{array}$ & & $\mathrm{X}$ & & $\mathrm{X}$ & & $\mathrm{X}$ & $X$ & & $\mathrm{X}$ & $\mathrm{X}$ & & \\
\hline $\begin{array}{l}\text { (ACS074) Verify the }-Y \text { magneto torque coil provides telemetry after System Board } \\
\text { digital command or power on. }\end{array}$ & & $\mathrm{X}$ & & $\mathrm{X}$ & & $\mathrm{X}$ & $X$ & & $\mathrm{X}$ & $\mathrm{X}$ & & \\
\hline $\begin{array}{l}\text { (ACS075) Verify the }+Y \text { magneto torque coil provides telemetry after System Board } \\
\text { digital command or power on. }\end{array}$ & & $\mathrm{X}$ & & $X$ & & $\mathrm{X}$ & $\mathrm{X}$ & & $\mathrm{X}$ & $\mathrm{X}$ & & \\
\hline $\begin{array}{l}\text { (ACS076) Verify the }-\mathrm{X} \text { magneto torque coil provides telemetry after System Board } \\
\text { digital command or power on. }\end{array}$ & & $\mathrm{X}$ & & $\mathrm{X}$ & & $\mathrm{X}$ & $\mathrm{X}$ & & $\mathrm{X}$ & $\mathrm{X}$ & & \\
\hline $\begin{array}{l}\text { (ACS077) Verify the }+X \text { magneto torque coil provides telemetry after System Board } \\
\text { digital command or power on. }\end{array}$ & & $\mathrm{X}$ & & $\mathrm{X}$ & & $\mathrm{X}$ & $\mathrm{X}$ & & $\mathrm{X}$ & $\mathrm{X}$ & & \\
\hline $\begin{array}{l}\text { (ACS078) Verify the }-\mathrm{Z} \text { magneto torque coil provides telemetry after System Board } \\
\text { digital command or power on. }\end{array}$ & & $\mathrm{X}$ & & $\mathrm{X}$ & & $\mathrm{X}$ & $\mathrm{X}$ & & $X$ & $X$ & & \\
\hline $\begin{array}{l}\text { (ACS079) Verify the }+Z \text { magneto torque coil provides telemetry after System Board } \\
\text { digital command or power on. }\end{array}$ & & $X$ & & $X$ & & $X$ & $X$ & & $X$ & $X$ & & \\
\hline $\begin{array}{l}\text { (ACS080) Verify the polarity of the }-Y \text { magneto torque coil output from telemetry as } \\
\text { compared to a known source. }\end{array}$ & & & & $X$ & & & $X$ & & & & & \\
\hline $\begin{array}{l}\text { (ACS081) Verify the polarity of the }+Y \text { magneto torque coil output from telemetry as } \\
\text { compared to a known source. }\end{array}$ & & & & $X$ & & & $X$ & & & & & \\
\hline
\end{tabular}




\begin{tabular}{|c|c|c|c|c|c|c|c|c|c|c|c|c|}
\hline \multirow{2}{*}{ Magneto Torque Coil Test Requirement } & \multicolumn{12}{|c|}{ Phase } \\
\hline & 1 & 2 & 3 & 4 & 5 & 6 & 7 & 8 & 9 & 10 & 11 & 12 \\
\hline $\begin{array}{l}\text { (ACS082) Verify the polarity of the }-\mathrm{X} \text { magneto torque coil output from telemetry as } \\
\text { compared to a known source. }\end{array}$ & & & & $\mathrm{X}$ & & & $\mathrm{X}$ & & & & & \\
\hline $\begin{array}{l}\text { (ACS083) Verify the polarity of the }+\mathrm{X} \text { magneto torque coil output from telemetry as } \\
\text { compared to a known source. }\end{array}$ & & & & $\mathrm{X}$ & & & $\mathrm{X}$ & & & & & \\
\hline $\begin{array}{l}\text { (ACS084) Verify the polarity of the }-\mathrm{Z} \text { magneto torque coil output from telemetry as } \\
\text { compared to a known source. }\end{array}$ & & & & $\mathrm{X}$ & & & $\mathrm{X}$ & & & & & \\
\hline $\begin{array}{l}\text { (ACS085) Verify the polarity of the }+\mathrm{Z} \text { magneto torque coil output from telemetry as } \\
\text { compared to a known source. }\end{array}$ & & & & $\mathrm{X}$ & & & $\mathrm{X}$ & & & & & \\
\hline $\begin{array}{l}\text { (ACS086) Verify that all magneto torque coil magnetic field intensity telemetry values } \\
\text { are within a minimum of } 10 \% \text { of each other. }\end{array}$ & & & & $\mathrm{X}$ & & $\mathrm{X}$ & $\mathrm{X}$ & & $\mathrm{X}$ & $\mathrm{X}$ & & \\
\hline
\end{tabular}

\subsubsection{Rate Sensor Gyroscope Test Requirements}




\begin{tabular}{|c|c|c|c|c|c|c|c|c|c|c|c|c|}
\hline \multirow{2}{*}{ Rate Sensor Gyroscope Test Requirement } & \multicolumn{12}{|c|}{ Phase } \\
\hline & 1 & 2 & 3 & 4 & 5 & 6 & 7 & 8 & 9 & 10 & 11 & 12 \\
\hline (ACS087) Verify the System Board supplies power to the Gyroscope. & & $\mathrm{X}$ & $\mathrm{X}$ & $\mathrm{X}$ & & $\mathrm{X}$ & $\mathrm{X}$ & & $\mathrm{X}$ & $\mathrm{X}$ & & \\
\hline $\begin{array}{l}\text { (ACS088) Verify via telemetry the System Board capability to disable the Gyroscope } \\
\text { power. }\end{array}$ & & $\mathrm{X}$ & & $\mathrm{X}$ & & $\mathrm{X}$ & $\mathrm{X}$ & & $\mathrm{X}$ & $\mathrm{X}$ & & \\
\hline $\begin{array}{l}\text { (ACS089) Verify via telemetry the System Board capability to enable the Gyroscope } \\
\text { power. }\end{array}$ & & $\mathrm{X}$ & & $\mathrm{X}$ & & $\mathrm{X}$ & $\mathrm{X}$ & & $\mathrm{X}$ & $X$ & & \\
\hline $\begin{array}{l}\text { (ACS090) Verify the Gyroscope standby state is initiated via digital command from the } \\
\text { System Board. }\end{array}$ & & $X$ & & $X$ & & $\mathrm{X}$ & $X$ & & $X$ & $X$ & & \\
\hline $\begin{array}{l}\text { (ACS091) Verify the Gyroscope nominal state is initiated via digital command from the } \\
\text { System Board. }\end{array}$ & & $X$ & & $X$ & & $\mathrm{X}$ & $X$ & & $X$ & $X$ & & \\
\hline $\begin{array}{l}\text { (ACS092) Verify the Gyroscope provides telemetry after System Board digital } \\
\text { command. }\end{array}$ & & $X$ & $X$ & $X$ & & $X$ & $X$ & & $X$ & $X$ & & \\
\hline $\begin{array}{l}\text { (ACS093) Verify the Gyroscope provides valid data from the active gyros (multiple, } 1 \\
\text { each axis, or only 1) when configured to run. }\end{array}$ & & $X$ & & $X$ & & $X$ & $X$ & & & & & \\
\hline $\begin{array}{l}\text { (ACS094) Verify the Gyroscope performs a calibration after System Board digital } \\
\text { command. }\end{array}$ & & $X$ & & $X$ & & $X$ & $X$ & & & & & \\
\hline
\end{tabular}

\subsubsection{Sun Sensor Test Requirements}




\begin{tabular}{|c|c|c|c|c|c|c|c|c|c|c|c|c|}
\hline \multirow{2}{*}{ Sun Sensor Test Requirement } & \multicolumn{12}{|c|}{ Phase } \\
\hline & 1 & 2 & 3 & 4 & 5 & 6 & 7 & 8 & 9 & 10 & 11 & 12 \\
\hline $\begin{array}{l}\text { (ACS095) Verify via telemetry the - Y sun sensor responds to light and properly } \\
\text { supplies sensor signal to the System Board. }\end{array}$ & & $\mathrm{X}$ & & $\mathrm{X}$ & & & $X$ & & $\mathrm{X}$ & $\mathrm{X}$ & & \\
\hline $\begin{array}{l}\text { (ACS096) Verify via telemetry the }+ \text { Y sun sensor responds to light and properly } \\
\text { supplies sensor signal to the System Board. }\end{array}$ & & $\mathrm{X}$ & & $\mathrm{X}$ & & & $\mathrm{X}$ & & $\mathrm{X}$ & $\mathrm{X}$ & & \\
\hline $\begin{array}{l}\text { (ACS097) Verify via telemetry the }-\mathrm{X} \text { sun sensor responds to light and properly } \\
\text { supplies sensor signal to the System Board. }\end{array}$ & & $\mathrm{X}$ & & $\mathrm{X}$ & & & $\mathrm{X}$ & & $\mathrm{X}$ & $\mathrm{X}$ & & \\
\hline $\begin{array}{l}\text { (ACS098) Verify via telemetry the }+X \text { sun sensor responds to light and properly } \\
\text { supplies sensor signal to the System Board. }\end{array}$ & & $\mathrm{X}$ & & $\mathrm{X}$ & & & $\mathrm{X}$ & & $\mathrm{X}$ & $\mathrm{X}$ & & \\
\hline $\begin{array}{l}\text { (ACS099) Verify via telemetry the }-\mathrm{Z} \text { sun sensor responds to light and properly } \\
\text { supplies sensor signal to the System Board. }\end{array}$ & & $\mathrm{X}$ & & $\mathrm{X}$ & & & $\mathrm{X}$ & & $\mathrm{X}$ & $\mathrm{X}$ & & \\
\hline $\begin{array}{l}\text { (ACS100) Verify via telemetry the }+Z \text { sun sensor responds to light and properly } \\
\text { supplies sensor signal to the System Board. }\end{array}$ & & $\mathrm{X}$ & & $\mathrm{X}$ & & & $\mathrm{X}$ & & $\mathrm{X}$ & $\mathrm{X}$ & & \\
\hline
\end{tabular}




\subsection{Command \& Data Handling Subsystem (C\&DH) Test Requirements}

The C\&DH Subsystem provides all data transmission, program and process execution and memory management functions. For most pico-satellites all command and data handling functions are processed through the motherboard so its components and functionality will be treated as a single unit. The C\&DH Subsystem (motherboard) also provides additional functionality like distributing power and as such will be referred to as the System Board. Separate tests will verify functionality between the components mounted on the System Board like telemetry and power through the $\mathrm{I} / \mathrm{O}$ interfaces or the ability to store data in memory.

The System Board has the ability to monitor regulated power, temperature and system processing functions. When sensor readings exceed their designated limits the sensor hard reboots the system to preclude hardware damage. Figure A5 depicts an example of Cal Poly CubeSat autonomous states, triggers and affected components. This will be used as a baseline for autonomous state testing. The test requirements to verify autonomous state functionality are dispersed between C\&DH and EPDS.

Figure A3 provide the I/O and component naming conventions. Table A4 lists the $\mathrm{C} \& \mathrm{DH}$ Subsystem capabilities being tested. 


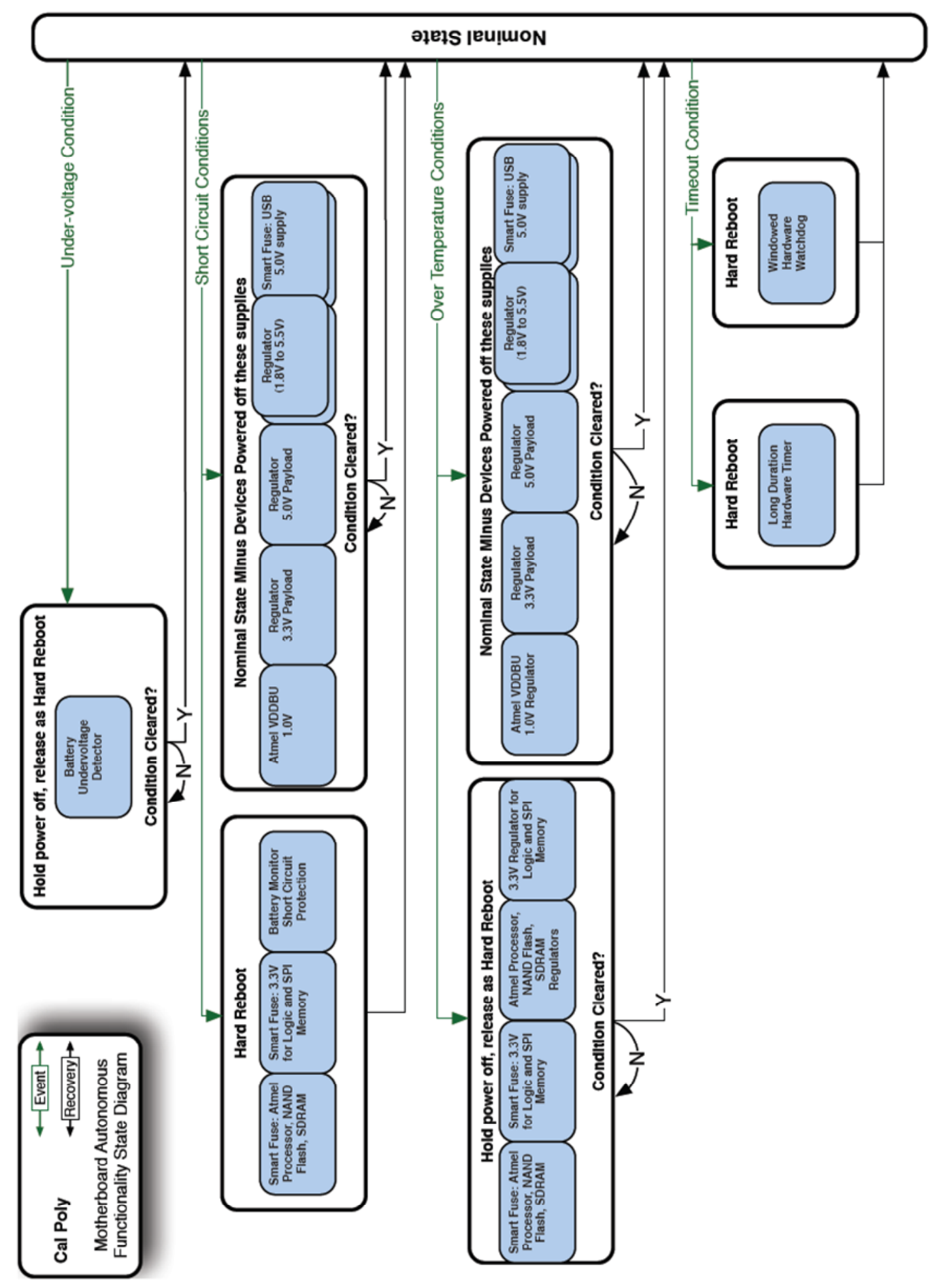

Figure A5: CubeSat Autonomous State Diagram Example

Figure courtesy of the Cal Poly PolySat Program 


\begin{tabular}{|l|l|l|}
\hline \multicolumn{2}{|c|}{ Table A4: C\&DH Subsystem Test Summary } \\
\hline Section & Section Title & Capability Being Tested \\
\hline 8.2 .1 & System Board & Verify power is supplied \\
& & Verify power regulation \\
& & Verify signal transmission \\
& & Verify telemetry storage and retrieval \\
& & Receive \& route SV / mission commands \\
& & Collect SV measured variables \\
& & Verify state entrance \\
& & Verify fault activation \\
\hline
\end{tabular}




\subsubsection{System Board Subsystem Test Requirements}

\begin{tabular}{|c|c|c|c|c|c|c|c|c|c|c|c|c|}
\hline \multirow{2}{*}{ System Board Subsystem Test Requirement } & \multicolumn{12}{|c|}{ Phase } \\
\hline & 1 & 2 & 3 & 4 & 5 & 6 & 7 & 8 & 9 & 10 & 11 & 12 \\
\hline (CDH001) Verify the System Board supplies power to the Daughterboard A interface. & $\mathrm{X}$ & & & & & & & & & & & \\
\hline $\begin{array}{l}\text { (CDH002) Verify telemetry transmission occurs through the Daughterboard A } \\
\text { interface. }\end{array}$ & $\mathrm{X}$ & & & & & & & & & & & \\
\hline (CDH003) Verify the System Board supplies power to the Daughterboard B interface. & $\mathrm{X}$ & & & & & & & & & & & \\
\hline $\begin{array}{l}\text { (CDH004) Verify telemetry transmission occurs through the Daughterboard B } \\
\text { interface. }\end{array}$ & $\mathrm{X}$ & & & & & & & & & & & \\
\hline (CDH005) Verify the System Board supplies power to the Interboard Stack interface. & $X$ & & & & & & & & & & & \\
\hline (CDH006) Verify telemetry transmission occurs through the Interboard Stack interface. & $X$ & & & & & & & & & & & \\
\hline $\begin{array}{l}\text { (CDH007) Verify the System Board supplies power to the Payload Interboard Stack } \\
\text { interface. }\end{array}$ & $\mathrm{X}$ & & & & & & & & & & & \\
\hline $\begin{array}{l}\text { (CDH008) Verify telemetry transmission occurs through the Payload Interboard Stack } \\
\text { interface. }\end{array}$ & $\mathrm{X}$ & & & & & & & & & & & \\
\hline $\begin{array}{l}\text { (CDH009) Verify the System Board supplies power to the Payload Programming FFC } \\
\text { interface. }\end{array}$ & $\mathrm{X}$ & & & & & & & & & & & \\
\hline $\begin{array}{l}\text { (CDH010) Verify telemetry transmission occurs through the Payload Programming } \\
\text { FFC interface. }\end{array}$ & $\mathrm{X}$ & & & & & & & & & & & \\
\hline
\end{tabular}




\begin{tabular}{|c|c|c|c|c|c|c|c|c|c|c|c|c|}
\hline \multirow{2}{*}{ System Board Subsystem Test Requirement } & \multicolumn{12}{|c|}{ Phase } \\
\hline & 1 & 2 & 3 & 4 & 5 & 6 & 7 & 8 & 9 & 10 & 11 & 12 \\
\hline $\begin{array}{l}\text { (CDH011) Verify the System Board supplies power to the Battery Module FFC } \\
\text { interface. }\end{array}$ & $\mathrm{X}$ & & & & & & & & & & & \\
\hline $\begin{array}{l}\text { (CDH012) Verify telemetry transmission occurs through the Battery Module FFC } \\
\text { interface. }\end{array}$ & $\mathrm{X}$ & & & & & & & & & & & \\
\hline (CDH013) Verify the System Board structural ground reads 0 ohms. & $\mathrm{X}$ & $\mathrm{X}$ & $\mathrm{X}$ & $\mathrm{X}$ & & $\mathrm{X}$ & $\mathrm{X}$ & & $\mathrm{X}$ & $\mathrm{X}$ & & \\
\hline (CDH014) Verify the EPDS supplies power to the System Board. & & $\mathrm{X}$ & $\mathrm{X}$ & $\mathrm{X}$ & & $\mathrm{X}$ & $\mathrm{X}$ & & $\mathrm{X}$ & $X$ & & \\
\hline $\begin{array}{l}\text { (CDH015) Verify the generated solar power received from the }-Y \text { Solar Panel is } \\
\text { distributed to the EPDS. }\end{array}$ & & $X$ & $X$ & $X$ & & & $X$ & & & & & \\
\hline $\begin{array}{l}\text { (CDH016) Verify the generated solar power received from the }+Y \text { Solar Panel is } \\
\text { distributed to the EPDS. }\end{array}$ & & $X$ & $X$ & $X$ & & & $X$ & & & & & \\
\hline $\begin{array}{l}\text { (CDH017) Verify the generated solar power received from the }-\mathrm{X} \text { Solar Panel is } \\
\text { distributed to the EPDS. }\end{array}$ & & $X$ & $X$ & $X$ & & & $X$ & & & & & \\
\hline $\begin{array}{l}\text { (CDH018) Verify the generated solar power received from the }+X \text { Solar Panel is } \\
\text { distributed to the EPDS. }\end{array}$ & & $X$ & $X$ & $X$ & & & $X$ & & & & & \\
\hline $\begin{array}{l}\text { (CDH019) Verify the generated solar power received from the }-\mathrm{Z} \text { Solar Panel is } \\
\text { distributed to the EPDS. }\end{array}$ & & $X$ & $X$ & $X$ & & & $X$ & & & & & \\
\hline $\begin{array}{l}\text { (CDH020) Verify the generated solar power received from the }+Z \text { Solar Panel is } \\
\text { distributed to the EPDS. }\end{array}$ & & $X$ & $X$ & $X$ & & & $X$ & & & & & \\
\hline
\end{tabular}




\begin{tabular}{|c|c|c|c|c|c|c|c|c|c|c|c|c|}
\hline \multirow{2}{*}{ System Board Subsystem Test Requirement } & \multicolumn{12}{|c|}{ Phase } \\
\hline & 1 & 2 & 3 & 4 & 5 & 6 & 7 & 8 & 9 & 10 & 11 & 12 \\
\hline $\begin{array}{l}\text { (CDH021) Verify via telemetry the system executes a hard reboots and returns to the } \\
\text { nominal low power state within } 5 \text { mins of initiation. }\end{array}$ & & $\mathrm{X}$ & & $\mathrm{X}$ & & $\mathrm{X}$ & $\mathrm{X}$ & & $\mathrm{X}$ & $\mathrm{X}$ & & \\
\hline $\begin{array}{l}\text { (CDH022) Verify via telemetry the Process Smart Fuse initiates a system hard reboot } \\
\text { after detecting a short circuit condition. }\end{array}$ & $\mathrm{X}$ & & & & & & & & & & & \\
\hline $\begin{array}{l}\text { (CDH023) Verify via telemetry the Flash Memory Smart Fuse initiates a system hard } \\
\text { reboot after detecting a short circuit condition. }\end{array}$ & $X$ & & & & & & & & & & & \\
\hline $\begin{array}{l}\text { (CDH024) Verify via telemetry the SDRAM Smart Fuse initiates a system hard reboot } \\
\text { after detecting a short circuit condition. }\end{array}$ & $X$ & & & & & & & & & & & \\
\hline $\begin{array}{l}\text { (CDH025) Verify via telemetry the Memory Smart Fuse initiates a system hard reboot } \\
\text { after detecting a short circuit condition. }\end{array}$ & $\mathrm{X}$ & & & & & & & & & & & \\
\hline $\begin{array}{l}\text { (CDH026) Verify via telemetry the Logic Smart Fuse initiates a system hard reboot } \\
\text { after detecting a short circuit condition. }\end{array}$ & $\mathrm{X}$ & & & & & & & & & & & \\
\hline $\begin{array}{l}\text { (CDH027) Verify via telemetry the Process Smart Fuse initiates a system hard reboot } \\
\text { after detecting an over-temperature condition. }\end{array}$ & $\mathrm{X}$ & & & & & & & & & & & \\
\hline $\begin{array}{l}\text { (CDH028) Verify via telemetry the Flash Memory Smart Fuse initiates a system hard } \\
\text { reboot after detecting an over-temperature condition. }\end{array}$ & $X$ & & & & & & & & & & & \\
\hline $\begin{array}{l}\text { (CDH029) Verify via telemetry the SDRAM Smart Fuse initiates a system hard reboot } \\
\text { after detecting an over-temperature condition. }\end{array}$ & $X$ & & & & & & & & & & & \\
\hline
\end{tabular}




\begin{tabular}{|c|c|c|c|c|c|c|c|c|c|c|c|c|}
\hline \multirow{2}{*}{ System Board Subsystem Test Requirement } & \multicolumn{12}{|c|}{ Phase } \\
\hline & 1 & 2 & 3 & 4 & 5 & 6 & 7 & 8 & 9 & 10 & 11 & 12 \\
\hline $\begin{array}{l}\text { (CDH030) Verify via telemetry the Memory Smart Fuse initiates a system hard reboot } \\
\text { after detecting an over-temperature condition. }\end{array}$ & $\mathrm{X}$ & & & & & & & & & & & \\
\hline $\begin{array}{l}\text { (CDH031) Verify via telemetry the Logic Smart Fuse initiates a system hard reboot } \\
\text { after detecting an over-temperature condition. }\end{array}$ & $\mathrm{X}$ & & & & & & & & & & & \\
\hline $\begin{array}{l}\text { (CDH032) Verify via telemetry the Processor Smart Fuse triggers a system hard reboot } \\
\text { after reaching } 20 \% \text { above the expected maximum peak current. }\end{array}$ & $\mathrm{X}$ & & & & & & & & & & & \\
\hline $\begin{array}{l}\text { (CDH033) Verify via telemetry the Flash Memory Smart Fuse triggers a system hard } \\
\text { reboot after reaching } 20 \% \text { above the expected maximum peak current. }\end{array}$ & $X$ & & & & & & & & & & & \\
\hline $\begin{array}{l}\text { (CDH034) Verify via telemetry the SDRAM Smart Fuse triggers a system hard reboot } \\
\text { after reaching } 20 \% \text { above the expected maximum peak current. }\end{array}$ & $\mathrm{X}$ & & & & & & & & & & & \\
\hline $\begin{array}{l}\text { (CDH035) Verify via telemetry the Memory Smart Fuse triggers a system hard reboot } \\
\text { after reaching } 20 \% \text { above the expected maximum peak current. }\end{array}$ & $\mathrm{X}$ & & & & & & & & & & & \\
\hline $\begin{array}{l}\text { (CDH036) Verify via telemetry the Logic Smart Fuse triggers a system hard reboot } \\
\text { after reaching } 20 \% \text { above the expected maximum peak current. }\end{array}$ & $\mathrm{X}$ & & & & & & & & & & & \\
\hline $\begin{array}{l}\text { (CDH037) Verify via telemetry the USB Smart Fuse } 1 \text { disables power upon detecting a } \\
\text { short circuit condition. }\end{array}$ & $\mathrm{X}$ & & & & & & & & & & & \\
\hline $\begin{array}{l}\text { (CDH038) Verify via telemetry the USB Smart Fuse } 2 \text { disables power upon detecting a } \\
\text { short circuit condition. }\end{array}$ & $X$ & & & & & & & & & & & \\
\hline
\end{tabular}




\begin{tabular}{|c|c|c|c|c|c|c|c|c|c|c|c|c|}
\hline \multirow{2}{*}{ System Board Subsystem Test Requirement } & \multicolumn{12}{|c|}{ Phase } \\
\hline & 1 & 2 & 3 & 4 & 5 & 6 & 7 & 8 & 9 & 10 & 11 & 12 \\
\hline $\begin{array}{l}\text { (CDH039) Verify via telemetry the USB Smart Fuse } 1 \text { disables power upon detecting } \\
\text { an over temperature condition. }\end{array}$ & $\mathrm{X}$ & & & & & & & & & & & \\
\hline $\begin{array}{l}\text { (CDH040) Verify via telemetry the USB Smart Fuse } 2 \text { disables power upon detecting } \\
\text { an over temperature condition. }\end{array}$ & $\mathrm{X}$ & & & & & & & & & & & \\
\hline $\begin{array}{l}\text { (CDH041) Verify via telemetry the Windowed Hardware Watchdog initiates a system } \\
\text { hard reboot after triggering a timeout condition. }\end{array}$ & $\mathrm{X}$ & & & & & & & & & & & \\
\hline $\begin{array}{l}\text { (CDH042) Verify via telemetry the Long Duration Hardware Timer initiates a system } \\
\text { hard reboot after triggering a timeout condition. }\end{array}$ & $\mathrm{X}$ & & & & & & & & & & & \\
\hline $\begin{array}{l}\text { (CDH043) Verify the System Board accepts and stores to memory received commands } \\
\text { through the Umbilical A interface. }\end{array}$ & & $\mathrm{X}$ & $\mathrm{X}$ & $\mathrm{X}$ & & $\mathrm{X}$ & $\mathrm{X}$ & & $\mathrm{X}$ & $\mathrm{X}$ & & $X$ \\
\hline $\begin{array}{l}\text { (CDH044) Verify the System Board accepts and stores to memory received commands } \\
\text { through the Umbilical B interface. }\end{array}$ & & $\mathrm{X}$ & $\mathrm{X}$ & $\mathrm{X}$ & & $\mathrm{X}$ & $X$ & & $\mathrm{X}$ & $\mathrm{X}$ & & $X$ \\
\hline $\begin{array}{l}\text { (CDH045) Verify the System Board accepts and stores to memory received telemetry } \\
\text { from the Transceiver. }\end{array}$ & & $\mathrm{X}$ & $\mathrm{X}$ & $\mathrm{X}$ & & $\mathrm{X}$ & $\mathrm{X}$ & & $\mathrm{X}$ & $\mathrm{X}$ & & \\
\hline (CDH046) Verify the System Board transmits telemetry to the Transceiver. & & $\mathrm{X}$ & $\mathrm{X}$ & $\mathrm{X}$ & & $\mathrm{X}$ & $\mathrm{X}$ & & $\mathrm{X}$ & $\mathrm{X}$ & & \\
\hline (CDH047) Verify when the Remove Before Flight pin is engaged the SV shuts off. & $\mathrm{X}$ & & & & & & & & & & & \\
\hline $\begin{array}{l}\text { (CDH048) Verify when the Remove Before Flight pin is disengaged the SV can begin } \\
\text { the boot up sequence. }\end{array}$ & $\mathrm{X}$ & & & & & & & & & & & \\
\hline
\end{tabular}




\begin{tabular}{|c|c|c|c|c|c|c|c|c|c|c|c|c|}
\hline \multirow{2}{*}{ System Board Subsystem Test Requirement } & \multicolumn{12}{|c|}{ Phase } \\
\hline & 1 & 2 & 3 & 4 & 5 & 6 & 7 & 8 & 9 & 10 & 11 & 12 \\
\hline (CDH049) Verify when the Deployment Switch is engaged the SV shuts off. & $\mathrm{X}$ & & & & & & & & & & & \\
\hline $\begin{array}{l}\text { (CDH050) Verify when the Deployment Switch is disengaged the SV can begin the } \\
\text { boot up sequence. }\end{array}$ & $\mathrm{X}$ & & & & & & & & & & & \\
\hline (CDH051) Verify the System Board can execute retrieved data from memory. & & $\mathrm{X}$ & $\mathrm{X}$ & $\mathrm{X}$ & & $\mathrm{X}$ & $\mathrm{X}$ & & $\mathrm{X}$ & $\mathrm{X}$ & & \\
\hline (CDH052) Verify the System Board can store data in memory. & & $\mathrm{X}$ & $\mathrm{X}$ & $\mathrm{X}$ & & $X$ & $X$ & & $X$ & $X$ & & \\
\hline $\begin{array}{l}\text { (CDH053) Verify the System Board receives and stores -Y Side Panel Power Sensor } \\
\text { telemetry. }\end{array}$ & & $X$ & $X$ & $X$ & & $X$ & $X$ & & & & & \\
\hline $\begin{array}{l}\text { (CDH054) Verify the System Board receives and stores }+ \text { Y Side Panel Power Sensor } \\
\text { telemetry. }\end{array}$ & & $X$ & $X$ & $X$ & & $X$ & $X$ & & & & & \\
\hline $\begin{array}{l}\text { (CDH055) Verify the System Board receives and stores -X Side Panel Power Sensor } \\
\text { telemetry. }\end{array}$ & & $X$ & $X$ & $X$ & & $X$ & $X$ & & & & & \\
\hline $\begin{array}{l}\text { (CDH056) Verify the System Board receives and stores }+X \text { Side Panel Power Sensor } \\
\text { telemetry. }\end{array}$ & & $X$ & $X$ & $X$ & & $X$ & $X$ & & & & & \\
\hline $\begin{array}{l}\text { (CDH057) Verify the System Board receives and stores }-Z \text { Side Panel Power Sensor } \\
\text { telemetry. }\end{array}$ & & $X$ & $X$ & $X$ & & $X$ & $X$ & & & & & \\
\hline $\begin{array}{l}\text { (CDH058) Verify the System Board receives and stores }+Z \text { Side Panel Power Sensor } \\
\text { telemetry. }\end{array}$ & & $X$ & $X$ & $X$ & & $X$ & $X$ & & & & & \\
\hline
\end{tabular}




\begin{tabular}{|c|c|c|c|c|c|c|c|c|c|c|c|c|}
\hline \multirow{2}{*}{ System Board Subsystem Test Requirement } & \multicolumn{12}{|c|}{ Phase } \\
\hline & 1 & 2 & 3 & 4 & 5 & 6 & 7 & 8 & 9 & 10 & 11 & 12 \\
\hline $\begin{array}{l}\text { (CDH059) Verify the System Board receives and stores System Board Power Sensor } \\
\text { telemetry. }\end{array}$ & & $\mathrm{X}$ & $\mathrm{X}$ & $\mathrm{X}$ & & $\mathrm{X}$ & $\mathrm{X}$ & & & & & \\
\hline $\begin{array}{l}\text { (CDH060) Verify the System Board receives and stores -Y Side Panel Temperature } \\
\text { Sensor telemetry. }\end{array}$ & & $\mathrm{X}$ & $\mathrm{X}$ & $\mathrm{X}$ & & $\mathrm{X}$ & $\mathrm{X}$ & & & & & \\
\hline $\begin{array}{l}\text { (CDH061) Verify the System Board receives and stores }+ \text { Y Side Panel Temperature } \\
\text { Sensor telemetry. }\end{array}$ & & $\mathrm{X}$ & $\mathrm{X}$ & $\mathrm{X}$ & & $\mathrm{X}$ & $\mathrm{X}$ & & & & & \\
\hline $\begin{array}{l}\text { (CDH062) Verify the System Board receives and stores -X Side Panel Temperature } \\
\text { Sensor telemetry. }\end{array}$ & & $\mathrm{X}$ & $\mathrm{X}$ & $\mathrm{X}$ & & $\mathrm{X}$ & $\mathrm{X}$ & & & & & \\
\hline $\begin{array}{l}\text { (CDH063) Verify the System Board receives and stores }+X \text { Side Panel Temperature } \\
\text { Sensor telemetry. }\end{array}$ & & $\mathrm{X}$ & $\mathrm{X}$ & $\mathrm{X}$ & & $\mathrm{X}$ & $\mathrm{X}$ & & & & & \\
\hline $\begin{array}{l}\text { (CDH064) Verify the System Board receives and stores }-\mathrm{Z} \text { Side Panel Temperature } \\
\text { Sensor telemetry. }\end{array}$ & & $\mathrm{X}$ & $\mathrm{X}$ & $\mathrm{X}$ & & $\mathrm{X}$ & $\mathrm{X}$ & & & & & \\
\hline $\begin{array}{l}\text { (CDH065) Verify the System Board receives and stores }+Z \text { Side Panel Temperature } \\
\text { Sensor telemetry. }\end{array}$ & & $\mathrm{X}$ & $\mathrm{X}$ & $\mathrm{X}$ & & $\mathrm{X}$ & $\mathrm{X}$ & & & & & \\
\hline $\begin{array}{l}\text { (CDH066) Verify the System Board receives and stores System Board Temperature } \\
\text { Sensor telemetry. }\end{array}$ & & $\mathrm{X}$ & $\mathrm{X}$ & $\mathrm{X}$ & & $\mathrm{X}$ & $\mathrm{X}$ & & & & & \\
\hline $\begin{array}{l}\text { (CDH067) Verify the System Board receives and stores Comm Subsystem Temperature } \\
\text { Sensor telemetry. }\end{array}$ & & $\mathrm{X}$ & $\mathrm{X}$ & $\mathrm{X}$ & & $\mathrm{X}$ & $\mathrm{X}$ & & & & & \\
\hline (CDH068) Verify the System Board receives and stores Payload telemetry. & & $\mathrm{X}$ & $\mathrm{X}$ & $\mathrm{X}$ & & $\mathrm{X}$ & $\mathrm{X}$ & & $\mathrm{X}$ & $\mathrm{X}$ & & \\
\hline
\end{tabular}




\begin{tabular}{|c|c|c|c|c|c|c|c|c|c|c|c|c|}
\hline \multirow{2}{*}{ System Board Subsystem Test Requirement } & \multicolumn{12}{|c|}{ Phase } \\
\hline & 1 & 2 & 3 & 4 & 5 & 6 & 7 & 8 & 9 & 10 & 11 & 12 \\
\hline $\begin{array}{l}\text { (CDH069) Verify the System Board maintains a minimum of a } 30 \text { minute separation } \\
\text { between deployment switch activation and signal initiation of deployable components. }\end{array}$ & & $\mathrm{X}$ & & $X$ & & & $X$ & & & & & \\
\hline $\begin{array}{l}\text { (CDH070) Verify the System Board maintains a minimum of } 45 \text { minutes separation } \\
\text { between deployment switch activation and signal initiation of RF transmission. }\end{array}$ & & $\mathrm{X}$ & & $X$ & & & $\mathrm{X}$ & & & & & \\
\hline
\end{tabular}




\subsection{Communication (Comm) Subsystem Test Requirements}

The Communication (Comm) Subsystem is responsible for receiving commands from the ground station and transmitting them to the processor for storage and execution. It also transmits data to the ground station which includes health, status and payload data. Figure A6 depicts a representative Comm Subsystem architecture which will be used for the functional test requirements generated.

As the Comm Subsystem is integral to mission success, most pico-satellites employ two identical Comm Subsystems, one primary and one redundant, to reduce the probability of loss of communication with the ground station. The requirements in this section assume only a primary system. For a redundant system, the requirements would be duplicated with the addition of tests to verify the switch from primary to redundant subsystems. Additionally, while the Modulation Unit is pictured as a separate component, it is typically software based, and is assumed as such for the purpose of the requirements. Lastly, all filters are assumed to be integral to the specific components they support. No specific requirements will be furnished for filters.

Table A5 lists the Comm Subsystem capabilities being tested. 


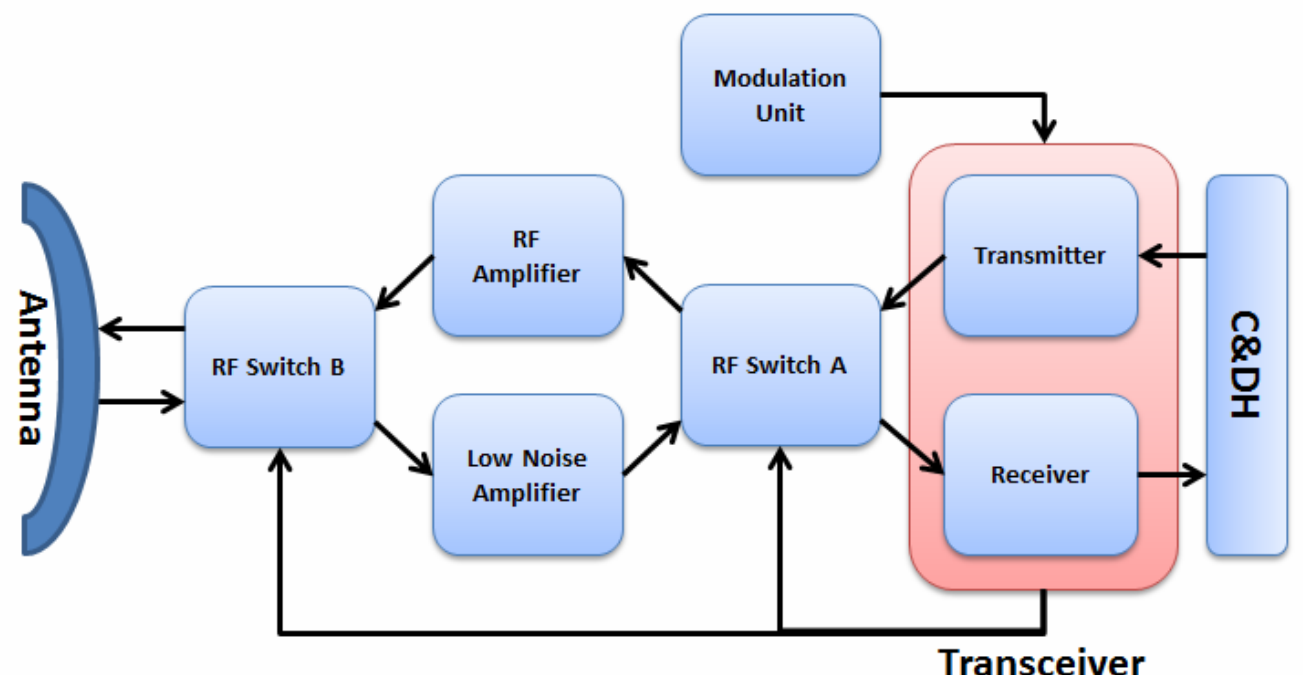

Figure A6: Comm Subsystem Example

Table A5: Comm Subsystem Test Summary

\begin{tabular}{|l|l|l|}
\hline Section & Section Title & Capability Being Tested \\
\hline 8.3 .1 & Antenna & $\begin{array}{l}\text { Verify power is supplied } \\
\text { Verify signal transmission }\end{array}$ \\
\hline 8.3 .2 & Low Noise Amplifier & $\begin{array}{l}\text { Verify power is supplied } \\
\text { Verify signal transmission }\end{array}$ \\
\hline 8.3 .3 & Radio Frequency Amplifier & $\begin{array}{l}\text { Verify power is supplied } \\
\text { Verify signal transmission } \\
\text { Verify signal enhancement }\end{array}$ \\
\hline 8.3 .4 & Radio Frequency Switch & $\begin{array}{l}\text { Verify power is supplied } \\
\text { Verify signal transmission } \\
\text { Verify state entrance }\end{array}$ \\
\hline
\end{tabular}




\begin{tabular}{|l|l|l|}
\hline \multicolumn{2}{|c|}{ Table A5: Comm Subsystem Test Summary } \\
\hline Section & Section Title & Capability Being Tested \\
\hline 8.3 .5 & Transceiver & Verify power is supplied \\
& & Verify signal transmission \\
& & Verify data rate \\
& & $\begin{array}{l}\text { Verify modulation scheme } \\
\text { Verify state entrance }\end{array}$ \\
& & Verify external signal transmission \\
& & Verify external command retrieval \\
\hline 8.3 .6 & Communication Subsystem & \\
& &
\end{tabular}




\subsubsection{Antenna Test Requirements}

\begin{tabular}{|c|c|c|c|c|c|c|c|c|c|c|c|c|}
\hline \multirow{2}{*}{ Antenna Test Requirement } & \multicolumn{12}{|c|}{ Phase } \\
\hline & 1 & 2 & 3 & 4 & 5 & 6 & 7 & 8 & 9 & 10 & 11 & 12 \\
\hline (COM001) Verify the System Board supplies power to the Antenna. & & $\mathrm{X}$ & $\mathrm{X}$ & $X$ & & $X$ & $\mathrm{X}$ & & $\mathrm{X}$ & $\mathrm{X}$ & & \\
\hline (COM002) Verify the Antenna transmits telemetry to the RF Switch B. & & $\mathrm{X}$ & $\mathrm{X}$ & $\mathrm{X}$ & & $\mathrm{X}$ & $\mathrm{X}$ & & $\mathrm{X}$ & $\mathrm{X}$ & & \\
\hline (COM003) Verify the Antenna receives telemetry from the RF Switch B. & & $\mathrm{X}$ & $\mathrm{X}$ & $X$ & & $\mathrm{X}$ & $\mathrm{X}$ & & $\mathrm{X}$ & $\mathrm{X}$ & & \\
\hline $\begin{array}{l}\text { (COM004) Verify via telemetry the Antenna receives telemetry from an external } \\
\text { source. }\end{array}$ & & & & $\mathrm{X}$ & & & $\mathrm{X}$ & & & & & \\
\hline (COM005) Verify via telemetry the Antenna transmits telemetry to an external source. & & & & $\mathrm{X}$ & & & $\mathrm{X}$ & & & & & \\
\hline
\end{tabular}

\subsubsection{Low Noise Amplifier Test Requirements}

\begin{tabular}{|c|c|c|c|c|c|c|c|c|c|c|c|c|}
\hline \multirow{2}{*}{ Low Noise Amplifier Test Requirement } & \multicolumn{12}{|c|}{ Phase } \\
\hline & 1 & 2 & 3 & 4 & 5 & 6 & 7 & 8 & 9 & 10 & 11 & 12 \\
\hline (COM006) Verify the System Board supplies power to the Low Noise Amplifier. & & $\mathrm{X}$ & $\mathrm{X}$ & $\mathrm{X}$ & & $\mathrm{X}$ & $\mathrm{X}$ & & $\mathrm{X}$ & $\mathrm{X}$ & & \\
\hline (COM007) Verify the Low Noise Amplifier transmits telemetry to the RF Switch A. & & $\mathrm{X}$ & $\mathrm{X}$ & $\mathrm{X}$ & & $\mathrm{X}$ & $\mathrm{X}$ & & $\mathrm{X}$ & $\mathrm{X}$ & & \\
\hline (COM008) Verify the Low Noise Amplifier receives telemetry from the RF Switch B. & & $\mathrm{X}$ & $\mathrm{X}$ & $\mathrm{X}$ & & $\mathrm{X}$ & $\mathrm{X}$ & & $\mathrm{X}$ & $\mathrm{X}$ & & \\
\hline
\end{tabular}




\subsubsection{Radio Frequency Amplifier Test Requirements}

\begin{tabular}{|c|c|c|c|c|c|c|c|c|c|c|c|c|}
\hline \multirow{2}{*}{ Radio Frequency Amplifier Test Requirement } & \multicolumn{12}{|c|}{ Phase } \\
\hline & 1 & 2 & 3 & 4 & 5 & 6 & 7 & 8 & 9 & 10 & 11 & 12 \\
\hline (COM009) Verify the System Board supplies power to the RF Amplifier. & & $\mathrm{X}$ & $\mathrm{X}$ & $\mathrm{X}$ & & $\mathrm{X}$ & $\mathrm{X}$ & & $\mathrm{X}$ & $\mathrm{X}$ & & \\
\hline (COM010) Verify the RF Amplifier transmits telemetry to the RF Switch B. & & $\mathrm{X}$ & $\mathrm{X}$ & $\mathrm{X}$ & & $\mathrm{X}$ & $\mathrm{X}$ & & $\mathrm{X}$ & $\mathrm{X}$ & & \\
\hline (COM011) Verify the RF Amplifier receives telemetry from the RF Switch A. & & $\mathrm{X}$ & $\mathrm{X}$ & $\mathrm{X}$ & & $X$ & $X$ & & $X$ & $X$ & & \\
\hline $\begin{array}{l}\text { (COM012) Verify via telemetry the System Board capability to disable the RF } \\
\text { Amplifier power. }\end{array}$ & & $X$ & & $X$ & & $X$ & $X$ & & $X$ & $X$ & & \\
\hline $\begin{array}{l}\text { (COM013) Verify via telemetry the System Board capability to enable the RF } \\
\text { Amplifier power. }\end{array}$ & & $X$ & & $X$ & & $X$ & $X$ & & $X$ & $X$ & & \\
\hline $\begin{array}{l}\text { (COM014) Verify the RF Amplifier can transmit telemetry using a power amplification } \\
\text { range of } 100 \mathrm{~mW} \text { to } 1.5 \mathrm{~W} \text {. }\end{array}$ & & $X$ & $X$ & $X$ & & $X$ & $X$ & & $X$ & $X$ & & \\
\hline
\end{tabular}




\subsubsection{Radio Frequency Switch Test Requirements}

\begin{tabular}{|c|c|c|c|c|c|c|c|c|c|c|c|c|}
\hline \multirow{2}{*}{ Radio Frequency Switch Test Requirement } & \multicolumn{12}{|c|}{ Phase } \\
\hline & 1 & 2 & 3 & 4 & 5 & 6 & 7 & 8 & 9 & 10 & 11 & 12 \\
\hline (COM015) Verify the System Board supplies power to the RF Switch A. & & $\mathrm{X}$ & $\mathrm{X}$ & $\mathrm{X}$ & & $\mathrm{X}$ & $\mathrm{X}$ & & $\mathrm{X}$ & $\mathrm{X}$ & & \\
\hline (COM016) Verify the System Board supplies power to the RF Switch B. & & $\mathrm{X}$ & $\mathrm{X}$ & $\mathrm{X}$ & & $\mathrm{X}$ & $X$ & & $\mathrm{X}$ & $\mathrm{X}$ & & \\
\hline (COM017) Verify the RF Switch A transmits telemetry to the RF Amplifier. & & $\mathrm{X}$ & $\mathrm{X}$ & $\mathrm{X}$ & & $\mathrm{X}$ & $\mathrm{X}$ & & $\mathrm{X}$ & $\mathrm{X}$ & & \\
\hline (COM018) Verify the RF Switch A receives telemetry from the Low Noise Amplifier. & & $\mathrm{X}$ & $\mathrm{X}$ & $\mathrm{X}$ & & $\mathrm{X}$ & $\mathrm{X}$ & & $\mathrm{X}$ & $\mathrm{X}$ & & \\
\hline (COM019) Verify the RF Switch A transmits telemetry to the Transceiver. & & $\mathrm{X}$ & $\mathrm{X}$ & $\mathrm{X}$ & & $\mathrm{X}$ & $\mathrm{X}$ & & $\mathrm{X}$ & $\mathrm{X}$ & & \\
\hline (COM020) Verify the RF Switch A receives telemetry from the Transceiver. & & $\mathrm{X}$ & $\mathrm{X}$ & $\mathrm{X}$ & & $\mathrm{X}$ & $\mathrm{X}$ & & $\mathrm{X}$ & $\mathrm{X}$ & & \\
\hline $\begin{array}{l}\text { (COM021) Verify the RF Switch A transmit state is initialized via Transceiver digital } \\
\text { command. }\end{array}$ & & $\mathrm{X}$ & $\mathrm{X}$ & $\mathrm{X}$ & & $\mathrm{X}$ & $\mathrm{X}$ & & $\mathrm{X}$ & $\mathrm{X}$ & & \\
\hline (COM022) Verify the RF Switch B transmits telemetry to the Antenna. & & $\mathrm{X}$ & $\mathrm{X}$ & $\mathrm{X}$ & & $\mathrm{X}$ & $\mathrm{X}$ & & $\mathrm{X}$ & $\mathrm{X}$ & & \\
\hline (COM023) Verify the RF Switch B receives telemetry from the Antenna. & & $\mathrm{X}$ & $\mathrm{X}$ & $\mathrm{X}$ & & $\mathrm{X}$ & $X$ & & $\mathrm{X}$ & $\mathrm{X}$ & & \\
\hline (COM024) Verify the RF Switch B transmits telemetry to the Low Noise Amplifier. & & $\mathrm{X}$ & $\mathrm{X}$ & $\mathrm{X}$ & & $\mathrm{X}$ & $\mathrm{X}$ & & $\mathrm{X}$ & $\mathrm{X}$ & & \\
\hline (COM025) Verify the RF Switch B receives telemetry from the RF Amplifier. & & $X$ & $\mathrm{X}$ & $\mathrm{X}$ & & $\mathrm{X}$ & $\mathrm{X}$ & & $\mathrm{X}$ & $\mathrm{X}$ & & \\
\hline $\begin{array}{l}\text { (COM026) Verify the RF Switch B transmit state is initialized via Transceiver digital } \\
\text { command. }\end{array}$ & & $\mathrm{X}$ & $\mathrm{X}$ & $\mathrm{X}$ & & $\mathrm{X}$ & $\mathrm{X}$ & & $\mathrm{X}$ & $\mathrm{X}$ & & \\
\hline
\end{tabular}




\subsubsection{Transceiver Test Requirements}

\begin{tabular}{|c|c|c|c|c|c|c|c|c|c|c|c|c|}
\hline \multirow{2}{*}{ Transceiver Test Requirement } & \multicolumn{12}{|c|}{ Phase } \\
\hline & 1 & 2 & 3 & 4 & 5 & 6 & 7 & 8 & 9 & 10 & 11 & 12 \\
\hline (COM027) Verify the System Board supplies power to the Transceiver. & & $X$ & $X$ & $X$ & & $X$ & X & & X & $X$ & & \\
\hline $\begin{array}{l}\text { (COM028) Verify the Transceiver transmits telemetry to the System Board after digital } \\
\text { command. }\end{array}$ & & $X$ & $X$ & $X$ & & $X$ & $X$ & & $\mathrm{X}$ & $\mathrm{X}$ & & \\
\hline (COM029) Verify the Transceiver receives telemetry from the System Board. & & $X$ & $\mathrm{X}$ & $X$ & & $\mathrm{X}$ & $X$ & & $X$ & $\mathrm{X}$ & & \\
\hline (COM030) Verify the Transceiver transmits telemetry to the RF Switch A. & & $X$ & $X$ & $X$ & & $X$ & $X$ & & $X$ & $\mathrm{X}$ & & \\
\hline (COM031) Verify the Transceiver receives telemetry from the RF Switch A. & & $\mathrm{X}$ & $\mathrm{X}$ & $X$ & & $\mathrm{X}$ & $\mathrm{X}$ & & $\mathrm{X}$ & $\mathrm{X}$ & & \\
\hline $\begin{array}{l}\text { (COM032) Verify the Transceiver commands RF Switch A and RF Switch B into } \\
\text { transmit state. }\end{array}$ & & $\mathrm{X}$ & $\mathrm{X}$ & $\mathrm{X}$ & & $\mathrm{X}$ & $\mathrm{X}$ & & $\mathrm{X}$ & $\mathrm{X}$ & & \\
\hline $\begin{array}{l}\text { (COM033) Verify the Transceiver decodes the received telemetry into the required data } \\
\text { format. }\end{array}$ & & $\mathrm{X}$ & $\mathrm{X}$ & $\mathrm{X}$ & & $\mathrm{X}$ & $\mathrm{X}$ & & $\mathrm{X}$ & $\mathrm{X}$ & & \\
\hline $\begin{array}{l}\text { (COM034) Verify the Transceiver encodes the received System Board telemetry into } \\
\text { the required data format. }\end{array}$ & & $\mathrm{X}$ & $\mathrm{X}$ & $\mathrm{X}$ & & $\mathrm{X}$ & $\mathrm{X}$ & & $\mathrm{X}$ & $\mathrm{X}$ & & \\
\hline (COM035) Verify the Transceiver modulates signals using FSK from 9.8 to $250 \mathrm{kbps}$. & & $\mathrm{X}$ & $\mathrm{X}$ & $\mathrm{X}$ & & $\mathrm{X}$ & $\mathrm{X}$ & & $\mathrm{X}$ & $\mathrm{X}$ & & \\
\hline (COM036) Verify the Transceiver modulates signals using GFSK from 9.8 to $250 \mathrm{kbps}$. & & $\mathrm{X}$ & $\mathrm{X}$ & $\mathrm{X}$ & & $\mathrm{X}$ & $\mathrm{X}$ & & $\mathrm{X}$ & $\mathrm{X}$ & & \\
\hline (COM037) Verify the Transceiver modulates signals using MSK from 9.8 to $250 \mathrm{kbps}$. & & $\mathrm{X}$ & $X$ & $X$ & & $X$ & $X$ & & $X$ & $X$ & & \\
\hline
\end{tabular}




\begin{tabular}{|c|c|c|c|c|c|c|c|c|c|c|c|c|}
\hline \multirow{2}{*}{ Transceiver Test Requirement } & \multicolumn{12}{|c|}{ Phase } \\
\hline & 1 & 2 & 3 & 4 & 5 & 6 & 7 & 8 & 9 & 10 & 11 & 12 \\
\hline $\begin{array}{l}\text { (COM038) Verify the Transceiver modulates signals using OQPSK from } 9.8 \text { to } 250 \\
\text { kbps. }\end{array}$ & & $\mathrm{X}$ & $\mathrm{X}$ & $\mathrm{X}$ & & $\mathrm{X}$ & $\mathrm{X}$ & & $\mathrm{X}$ & $\mathrm{X}$ & & \\
\hline $\begin{array}{l}\text { (COM039) Verify the Transceiver modulates signals using BPSK from } 19.2 \text { to } 600 \\
\text { kbps. }\end{array}$ & & $\mathrm{X}$ & $\mathrm{X}$ & $\mathrm{X}$ & & $\mathrm{X}$ & $\mathrm{X}$ & & $\mathrm{X}$ & $\mathrm{X}$ & & \\
\hline (COM040) Verify the Transceiver operates in the 400 to $470 \mathrm{MHz}$ band. & & $\mathrm{X}$ & $\mathrm{X}$ & $\mathrm{X}$ & & $\mathrm{X}$ & $X$ & & $\mathrm{X}$ & $\mathrm{X}$ & & \\
\hline (COM041) Verify the Transceiver operates in the 800 to $940 \mathrm{MHz}$ band. & & $\mathrm{X}$ & $\mathrm{X}$ & $\mathrm{X}$ & & $\mathrm{X}$ & $\mathrm{X}$ & & $\mathrm{X}$ & $\mathrm{X}$ & & \\
\hline $\begin{array}{l}\text { (COM042) Verify the Transceiver initializes an audible beacon to transmit telemetry } \\
\text { signals. }\end{array}$ & & $\mathrm{X}$ & & $\mathrm{X}$ & & $\mathrm{X}$ & $\mathrm{X}$ & & & & & \\
\hline (COM043) Verify the Transceiver enters the receive state upon power initialization. & & $\mathrm{X}$ & $\mathrm{X}$ & $\mathrm{X}$ & & $\mathrm{X}$ & $\mathrm{X}$ & & $\mathrm{X}$ & $\mathrm{X}$ & & \\
\hline $\begin{array}{l}\text { (COM044) Verify the Transceiver enters the transmission state after System Board } \\
\text { digital command. }\end{array}$ & & $\mathrm{X}$ & $\mathrm{X}$ & $\mathrm{X}$ & & $\mathrm{X}$ & $X$ & & $X$ & $X$ & & \\
\hline
\end{tabular}




\subsubsection{Communication Subsystem Test Requirements}

\begin{tabular}{|c|c|c|c|c|c|c|c|c|c|c|c|c|}
\hline \multirow{2}{*}{ Comm Subsystem Requirement } & \multicolumn{12}{|c|}{ Phase } \\
\hline & 1 & 2 & 3 & 4 & 5 & 6 & 7 & 8 & 9 & 10 & 11 & 12 \\
\hline $\begin{array}{l}\text { (COM045) Verify for a one (1) RF inhibiter system the power output is no greater than } \\
1.5 \mathrm{~W} \text {. }\end{array}$ & & $\mathrm{X}$ & & $\mathrm{X}$ & & & $\mathrm{X}$ & & & & & \\
\hline $\begin{array}{l}\text { (COM046) Verify the Comm Subsystem receives telemetry from the System Board and } \\
\text { transmits it to an external source. }\end{array}$ & & $\mathrm{X}$ & & $\mathrm{X}$ & & & $\mathrm{X}$ & & & & & \\
\hline $\begin{array}{l}\text { (COM047) Verify the Comm Subsystem receives telemetry from an external source } \\
\text { and transmits it to the System Board. }\end{array}$ & & $\mathrm{X}$ & & $\mathrm{X}$ & & & $\mathrm{X}$ & & & & & \\
\hline $\begin{array}{l}\text { (COM048) Verify the Comm Subsystem receives a transmitter shutdown command } \\
\text { from an external source. }\end{array}$ & & $\mathrm{X}$ & & $\mathrm{X}$ & & & $\mathrm{X}$ & & & & & \\
\hline $\begin{array}{l}\text { (COM049) Verify the Comm Subsystem maintains a minimum of } 45 \text { minute separation } \\
\text { between deployment switch activation and first RF transmission. }\end{array}$ & & $\mathrm{X}$ & & $\mathrm{X}$ & & & $\mathrm{X}$ & & & & & \\
\hline $\begin{array}{l}\text { (COM050) Verify the Comm Subsystem can transmit telemetry in the allotted ground } \\
\text { station communication window. }\end{array}$ & & $\mathrm{X}$ & & $\mathrm{X}$ & & & $\mathrm{X}$ & & & & & \\
\hline $\begin{array}{l}\text { (COM051) Verify the Comm Subsystem can receive and process telemetry in the } \\
\text { allotted ground station communication window. }\end{array}$ & & $\mathrm{X}$ & & $\mathrm{X}$ & & & $\mathrm{X}$ & & & & & \\
\hline
\end{tabular}




\subsection{Electrical Power Distribution Subsystem (EPDS) Test Requirements}

The EPDS generates and supplies power to the SV. The subsystem comprises of solar arrays for power generation, batteries to supply power to the SV through the System Board and a monitoring system for health and status.

While regulators exist as a component within multiple subsystems, their main function is to regulate the supplied power and distribute it to components. Therefore, they are grouped under EPDS instead of the individual subsystem they regulate.

Table A6 lists the EPDS capabilities being tested.

\begin{tabular}{|l|l|l|}
\hline \multicolumn{2}{|c|}{ Table A6: EPDS Test Summary } \\
\hline Section & Section Title & Capability Being Tested \\
\hline 8.4 .1 & Battery & $\begin{array}{l}\text { Verify power is supplied } \\
\text { Verify signal transmission } \\
\text { Power storage capability }\end{array}$ \\
\hline 8.4 .2 & Power Monitoring Unit & $\begin{array}{l}\text { Verify battery charge control } \\
\text { Verify cell balance functionality }\end{array}$ \\
\hline 8.4 .3 & Power Regulator & $\begin{array}{l}\text { Verify power is supplied } \\
\text { Verify signal transmission } \\
\text { Verify fault activation }\end{array}$ \\
\hline 8.4 .4 & Solar Array Panel & $\begin{array}{l}\text { Verify power generation } \\
\text { Verify power supply }\end{array}$ \\
\hline
\end{tabular}




\subsubsection{Battery Test Requirements}

\begin{tabular}{|c|c|c|c|c|c|c|c|c|c|c|c|c|}
\hline \multirow{2}{*}{ Battery Test Requirement } & \multicolumn{12}{|c|}{ Phase } \\
\hline & 1 & 2 & 3 & 4 & 5 & 6 & 7 & 8 & 9 & 10 & 11 & 12 \\
\hline $\begin{array}{l}\text { (EPS001) Verify Battery 1can be charged via GSE connected through an external } \\
\text { interface connection. }\end{array}$ & & $\mathrm{X}$ & & $\mathrm{X}$ & & & $\mathrm{X}$ & & $\mathrm{X}$ & $X$ & & $\mathrm{X}$ \\
\hline $\begin{array}{l}\text { (EPS002) Verify Battery } 1 \text { can be discharged via GSE connected through an external } \\
\text { interface connection. }\end{array}$ & & $X$ & & $\mathrm{X}$ & & & $\mathrm{X}$ & & $\mathrm{X}$ & $X$ & & $\mathrm{X}$ \\
\hline $\begin{array}{l}\text { (EPSO03) Verify Battery } 2 \text { can be charged via GSE connected through an external } \\
\text { interface connection. }\end{array}$ & & $\mathrm{X}$ & & $X$ & & & $\mathrm{X}$ & & $\mathrm{X}$ & $X$ & & $\mathrm{X}$ \\
\hline $\begin{array}{l}\text { (EPS004) Verify Battery } 2 \text { can be discharged via GSE connected through an external } \\
\text { interface connection. }\end{array}$ & & $X$ & & $X$ & & & $\mathrm{X}$ & & $\mathrm{X}$ & $\mathrm{X}$ & & $\mathrm{X}$ \\
\hline (EPS005) Verify Battery 1 voltage telemetry indicates the proper values. & & $\mathrm{X}$ & $\mathrm{X}$ & $X$ & & $\mathrm{X}$ & $\mathrm{X}$ & & $\mathrm{X}$ & $X$ & & \\
\hline (EPS006) Verify Battery 1 voltage telemetry indicates the proper value at the GSE. & & $X$ & & $\mathrm{X}$ & & & $\mathrm{X}$ & & $\mathrm{X}$ & $\mathrm{X}$ & & $\mathrm{X}$ \\
\hline (EPS007) Verify Battery 2 voltage telemetry indicates the proper values. & & $\mathrm{X}$ & $\mathrm{X}$ & $X$ & & $\mathrm{X}$ & $\mathrm{X}$ & & $X$ & $X$ & & \\
\hline (EPS008) Verify Battery 2 voltage telemetry indicates the proper value at the GSE. & & $\mathrm{X}$ & & $\mathrm{X}$ & & & $\mathrm{X}$ & & $\mathrm{X}$ & $\mathrm{X}$ & & $\mathrm{X}$ \\
\hline (EPS009) Verify Battery 1 completes a full charge and discharge cycle. & & & & $\mathrm{X}$ & & & $\mathrm{X}$ & & $\mathrm{X}$ & $\mathrm{X}$ & & \\
\hline (EPS010) Verify Battery 2 completes a full charge and discharge cycle. & & & & $\mathrm{X}$ & & & $\mathrm{X}$ & & $\mathrm{X}$ & $\mathrm{X}$ & & \\
\hline $\begin{array}{l}\text { (EPS011) Verify Battery } 1 \text { telemetry indicates the proper level over a complete charge } \\
\text { and discharge cycle. }\end{array}$ & & $\mathrm{X}$ & & $X$ & & $X$ & $X$ & & $X$ & $X$ & & \\
\hline
\end{tabular}




\begin{tabular}{|c|c|c|c|c|c|c|c|c|c|c|c|c|}
\hline \multirow{2}{*}{ Battery Test Requirement } & \multicolumn{12}{|c|}{ Phase } \\
\hline & 1 & 2 & 3 & 4 & 5 & 6 & 7 & 8 & 9 & 10 & 11 & 12 \\
\hline $\begin{array}{l}\text { (EPS012) Verify Battery } 1 \text { telemetry indicates the proper level at the GSE over a } \\
\text { complete charge and discharge cycle. }\end{array}$ & & $\mathrm{X}$ & & $\mathrm{X}$ & & $\mathrm{X}$ & $\mathrm{X}$ & & $\mathrm{X}$ & $\mathrm{X}$ & & $\mathrm{X}$ \\
\hline $\begin{array}{l}\text { (EPS013) Verify Battery } 2 \text { telemetry indicates the proper level over a complete charge } \\
\text { and discharge cycle. }\end{array}$ & & $\mathrm{X}$ & & $\mathrm{X}$ & & $\mathrm{X}$ & $\mathrm{X}$ & & $\mathrm{X}$ & $\mathrm{X}$ & & \\
\hline $\begin{array}{l}\text { (EPS014) Verify Battery } 2 \text { telemetry indicates the proper level at the GSE over a } \\
\text { complete charge and discharge cycle. }\end{array}$ & & $\mathrm{X}$ & & $\mathrm{X}$ & & $\mathrm{X}$ & $\mathrm{X}$ & & $\mathrm{X}$ & $\mathrm{X}$ & & $\mathrm{X}$ \\
\hline $\begin{array}{l}\text { (EPS015) Verify the isolation between the Battery } 1 \text { output and battery case is zero (0) } \\
\text { ohms. }\end{array}$ & $\mathrm{X}$ & & & & & & & & & & & \\
\hline $\begin{array}{l}\text { (EPS016) Verify the isolation between the Battery } 2 \text { output and battery case is zero (0) } \\
\text { ohms. }\end{array}$ & $\mathrm{X}$ & & & & & & & & & & & \\
\hline $\begin{array}{l}\text { (EPS017) Verify the voltage difference between the Battery loutput and battery case is } \\
\text { zero (0) volts. }\end{array}$ & $\mathrm{X}$ & & & & & & & & & & & \\
\hline $\begin{array}{l}\text { (EPS018) Verify the voltage difference between the Battery } 2 \text { output and battery case is } \\
\text { zero (0) volts. }\end{array}$ & $\mathrm{X}$ & & & & & & & & & & & \\
\hline
\end{tabular}

\subsubsection{Power Monitoring Test Requirements}




\begin{tabular}{|c|c|c|c|c|c|c|c|c|c|c|c|c|}
\hline \multirow{2}{*}{ Power Monitoring Test Requirement } & \multicolumn{12}{|c|}{ Phase } \\
\hline & 1 & 2 & 3 & 4 & 5 & 6 & 7 & 8 & 9 & 10 & 11 & 12 \\
\hline $\begin{array}{l}\text { (EPS019) Verify the Battery } 1 \text { temperature sensors indicate the proper levels on } \\
\text { telemetry. }\end{array}$ & & $\mathrm{X}$ & & $\mathrm{X}$ & & $\mathrm{X}$ & $\mathrm{X}$ & & $\mathrm{X}$ & $\mathrm{X}$ & & \\
\hline $\begin{array}{l}\text { (EPS020) Verify the Battery } 2 \text { temperature sensors indicate the proper levels on } \\
\text { telemetry. }\end{array}$ & & $\mathrm{X}$ & & $\mathrm{X}$ & & $\mathrm{X}$ & $X$ & & $\mathrm{X}$ & $\mathrm{X}$ & & \\
\hline $\begin{array}{l}\text { (EPSO21) Verify the generated solar power received from the }-Y \text { Solar Panel is } \\
\text { distributed to Battery } 1 .\end{array}$ & & $\mathrm{X}$ & $\mathrm{X}$ & $X$ & & & $\mathrm{X}$ & & & & & \\
\hline $\begin{array}{l}\text { (EPSO22) Verify the generated solar power received from the }+ \text { Y Solar Panel is } \\
\text { distributed to Battery } 1 .\end{array}$ & & $\mathrm{X}$ & $\mathrm{X}$ & $\mathrm{X}$ & & & $\mathrm{X}$ & & & & & \\
\hline $\begin{array}{l}\text { (EPSO23) Verify the generated solar power received from the }-\mathrm{X} \text { Solar Panel is } \\
\text { distributed to Battery } 1 .\end{array}$ & & $\mathrm{X}$ & $\mathrm{X}$ & $\mathrm{X}$ & & & $\mathrm{X}$ & & & & & \\
\hline $\begin{array}{l}\text { (EPSO24) Verify the generated solar power received from the }+\mathrm{X} \text { Solar Panel is } \\
\text { distributed to Battery } 1 .\end{array}$ & & $\mathrm{X}$ & $\mathrm{X}$ & $\mathrm{X}$ & & & $\mathrm{X}$ & & & & & \\
\hline $\begin{array}{l}\text { (EPSO25) Verify the generated solar power received from the }-Z \text { Solar Panel is } \\
\text { distributed to Battery } 1 .\end{array}$ & & $\mathrm{X}$ & $\mathrm{X}$ & $\mathrm{X}$ & & & $X$ & & & & & \\
\hline $\begin{array}{l}\text { (EPSO26) Verify the generated solar power received from the }+Z \text { Solar Panel is } \\
\text { distributed to Battery } 1 .\end{array}$ & & $\mathrm{X}$ & $\mathrm{X}$ & $\mathrm{X}$ & & & $\mathrm{X}$ & & & & & \\
\hline $\begin{array}{l}\text { (EPS027) Verify the generated solar power received from the }-Y \text { Solar Panel is } \\
\text { distributed to Battery } 2 \text {. }\end{array}$ & & $\mathrm{X}$ & $\mathrm{X}$ & $\mathrm{X}$ & & & $\mathrm{X}$ & & & & & \\
\hline
\end{tabular}




\begin{tabular}{|c|c|c|c|c|c|c|c|c|c|c|c|c|}
\hline \multirow{2}{*}{ Power Monitoring Test Requirement } & \multicolumn{12}{|c|}{ Phase } \\
\hline & 1 & 2 & 3 & 4 & 5 & 6 & 7 & 8 & 9 & 10 & 11 & 12 \\
\hline $\begin{array}{l}\text { (EPSO28) Verify the generated solar power received from the }+ \text { Y Solar Panel is } \\
\text { distributed to Battery } 2 \text {. }\end{array}$ & & $\mathrm{X}$ & $\mathrm{X}$ & $\mathrm{X}$ & & & $X$ & & & & & \\
\hline $\begin{array}{l}\text { (EPS029) Verify the generated solar power received from the }-\mathrm{X} \text { Solar Panel is } \\
\text { distributed to Battery } 2 \text {. }\end{array}$ & & $\mathrm{X}$ & $\mathrm{X}$ & $\mathrm{X}$ & & & $X$ & & & & & \\
\hline $\begin{array}{l}\text { (EPSO30) Verify the generated solar power received from the }+X \text { Solar Panel is } \\
\text { distributed to Battery } 2 \text {. }\end{array}$ & & $\mathrm{X}$ & $\mathrm{X}$ & $\mathrm{X}$ & & & $X$ & & & & & \\
\hline $\begin{array}{l}\text { (EPS031) Verify the generated solar power received from the }-Z \text { Solar Panel is } \\
\text { distributed to Battery } 2 .\end{array}$ & & $\mathrm{X}$ & $\mathrm{X}$ & $\mathrm{X}$ & & & $X$ & & & & & \\
\hline $\begin{array}{l}\text { (EPSO32) Verify the generated solar power received from the }+Z \text { Solar Panel is } \\
\text { distributed to Battery } 2 \text {. }\end{array}$ & & $\mathrm{X}$ & $\mathrm{X}$ & $\mathrm{X}$ & & & $\mathrm{X}$ & & & & & \\
\hline $\begin{array}{l}\text { (EPS033) Verify via telemetry the Battery Monitor Short Circuit Protection Electronics } \\
\text { initiates a system hard reboot after detecting a short circuit condition. }\end{array}$ & $X$ & & & & & & & & & & & \\
\hline $\begin{array}{l}\text { (EPS034) Verify via telemetry the Battery Undervoltage Detector initiates a system } \\
\text { hard reboot after detecting an under-voltage condition. }\end{array}$ & $X$ & & & & & & & & & & & \\
\hline (EPS035) Verify the System Board supplies power to the -Y Side Panel Power Sensor. & & $\mathrm{X}$ & $\mathrm{X}$ & $\mathrm{X}$ & & $\mathrm{X}$ & $\mathrm{X}$ & & & & & \\
\hline (EPS036) Verify the System Board supplies power to the + Y Side Panel Power Sensor. & & $\mathrm{X}$ & $\mathrm{X}$ & $\mathrm{X}$ & & $X$ & $\mathrm{X}$ & & & & & \\
\hline (EPS037) Verify the System Board supplies power to the $-X$ Side Panel Power Sensor. & & $\mathrm{X}$ & $\mathrm{X}$ & $\mathrm{X}$ & & $X$ & $\mathrm{X}$ & & & & & \\
\hline (EPS038) Verify the System Board supplies power to the $+X$ Side Panel Power Sensor. & & $\mathrm{X}$ & $\mathrm{X}$ & $\mathrm{X}$ & & $\mathrm{X}$ & $\mathrm{X}$ & & & & & \\
\hline
\end{tabular}




\begin{tabular}{|c|c|c|c|c|c|c|c|c|c|c|c|c|}
\hline \multirow{2}{*}{ Power Monitoring Test Requirement } & \multicolumn{12}{|c|}{ Phase } \\
\hline & 1 & 2 & 3 & 4 & 5 & 6 & 7 & 8 & 9 & 10 & 11 & 12 \\
\hline (EPS039) Verify the System Board supplies power to the $-Z$ Side Panel Power Sensor. & & $\mathrm{X}$ & $\mathrm{X}$ & $\mathrm{X}$ & & $\mathrm{X}$ & $\mathrm{X}$ & & & & & \\
\hline (EPS040) Verify the System Board supplies power to the $+Z$ Side Panel Power Sensor. & & $\mathrm{X}$ & $\mathrm{X}$ & $\mathrm{X}$ & & $X$ & $\mathrm{X}$ & & & & & \\
\hline (EPS041) Verify the System Board supplies power to System Board Power Sensor. & & $\mathrm{X}$ & $\mathrm{X}$ & $\mathrm{X}$ & & $\mathrm{X}$ & $X$ & & & & & \\
\hline $\begin{array}{l}\text { (EPS042) Verify the -Y Side Panel Power Sensor indicate the proper telemetry values } \\
\text { when power is applied. }\end{array}$ & & $\mathrm{X}$ & $\mathrm{X}$ & $\mathrm{X}$ & & $\mathrm{X}$ & $\mathrm{X}$ & & & & & \\
\hline $\begin{array}{l}\text { (EPS043) Verify the }+ \text { Y Side Panel Power Sensor indicate the proper telemetry values } \\
\text { when power is applied. }\end{array}$ & & $\mathrm{X}$ & $\mathrm{X}$ & $\mathrm{X}$ & & $\mathrm{X}$ & $\mathrm{X}$ & & & & & \\
\hline $\begin{array}{l}\text { (EPS044) Verify the }-X \text { Side Panel Power Sensor indicate the proper telemetry values } \\
\text { when power is applied. }\end{array}$ & & $\mathrm{X}$ & $\mathrm{X}$ & $\mathrm{X}$ & & $\mathrm{X}$ & $\mathrm{X}$ & & & & & \\
\hline $\begin{array}{l}\text { (EPS045) Verify the }+\mathrm{X} \text { Side Panel Power Sensor indicate the proper telemetry values } \\
\text { when power is applied. }\end{array}$ & & $\mathrm{X}$ & $\mathrm{X}$ & $\mathrm{X}$ & & $\mathrm{X}$ & $\mathrm{X}$ & & & & & \\
\hline $\begin{array}{l}\text { (EPS046) Verify the -Z Side Panel Power Sensor indicate the proper telemetry values } \\
\text { when power is applied. }\end{array}$ & & $\mathrm{X}$ & $X$ & $X$ & & $X$ & $X$ & & & & & \\
\hline $\begin{array}{l}\text { (EPS047) Verify the }+Z \text { Side Panel Power Sensor indicate the proper telemetry values } \\
\text { when power is applied. }\end{array}$ & & $X$ & $X$ & $X$ & & $\mathrm{X}$ & $X$ & & & & & \\
\hline $\begin{array}{l}\text { (EPS048) Verify the System Board Power Sensor indicate the proper telemetry values } \\
\text { when power is applied. }\end{array}$ & & $X$ & $X$ & $X$ & & $X$ & $X$ & & & & & \\
\hline
\end{tabular}




\begin{tabular}{|c|c|c|c|c|c|c|c|c|c|c|c|c|}
\hline \multirow{2}{*}{ Power Monitoring Test Requirement } & \multicolumn{12}{|c|}{ Phase } \\
\hline & $\mathbf{1}$ & 2 & 3 & 4 & 5 & 6 & 7 & 8 & 9 & 10 & 11 & 12 \\
\hline $\begin{array}{l}\text { (EPS049) Verify the -Y Side Panel Power Sensor transmits telemetry after System } \\
\text { Board digital sample command }\end{array}$ & & $\mathrm{X}$ & $\mathrm{X}$ & $\mathrm{X}$ & & $\mathrm{X}$ & $\mathrm{X}$ & & & & & \\
\hline $\begin{array}{l}\text { (EPS050) Verify the }+ \text { Y Side Panel Power Sensor transmits telemetry after System } \\
\text { Board digital sample command }\end{array}$ & & $\mathrm{X}$ & $\mathrm{X}$ & $\mathrm{X}$ & & $\mathrm{X}$ & $\mathrm{X}$ & & & & & \\
\hline $\begin{array}{l}\text { (EPS051) Verify the }-X \text { Side Panel Power Sensor transmits telemetry after System } \\
\text { Board digital sample command }\end{array}$ & & $\mathrm{X}$ & $\mathrm{X}$ & $\mathrm{X}$ & & $\mathrm{X}$ & $\mathrm{X}$ & & & & & \\
\hline $\begin{array}{l}\text { (EPS052) Verify the }+X \text { Side Panel Power Sensor transmits telemetry after System } \\
\text { Board digital sample command }\end{array}$ & & $\mathrm{X}$ & $\mathrm{X}$ & $\mathrm{X}$ & & $\mathrm{X}$ & $\mathrm{X}$ & & & & & \\
\hline $\begin{array}{l}\text { (EPS053) Verify the }-Z \text { Side Panel Power Sensor transmits telemetry after System } \\
\text { Board digital sample command }\end{array}$ & & $\mathrm{X}$ & $\mathrm{X}$ & $\mathrm{X}$ & & $\mathrm{X}$ & $\mathrm{X}$ & & & & & \\
\hline $\begin{array}{l}\text { (EPS054) Verify the }+Z \text { Side Panel Power Sensor transmits telemetry after System } \\
\text { Board digital sample command }\end{array}$ & & $\mathrm{X}$ & $\mathrm{X}$ & $\mathrm{X}$ & & $\mathrm{X}$ & $\mathrm{X}$ & & & & & \\
\hline $\begin{array}{l}\text { (EPS055) Verify the System Board Power Sensor transmits telemetry after System } \\
\text { Board digital sample command }\end{array}$ & & $\mathrm{X}$ & $\mathrm{X}$ & $\mathrm{X}$ & & $\mathrm{X}$ & $\mathrm{X}$ & & & & & \\
\hline
\end{tabular}

\subsubsection{Power Regulator Test Requirements}




\begin{tabular}{|c|c|c|c|c|c|c|c|c|c|c|c|c|}
\hline \multirow{2}{*}{ Power Regulator Test Requirement } & \multicolumn{12}{|c|}{ Phase } \\
\hline & 1 & 2 & 3 & 4 & 5 & 6 & 7 & 8 & 9 & 10 & 11 & 12 \\
\hline (EPS056) Verify the System Board supplies power to the 1.0V Regulator. & & $\mathrm{X}$ & $\mathrm{X}$ & $\mathrm{X}$ & & $\mathrm{X}$ & $\mathrm{X}$ & & $\mathrm{X}$ & $\mathrm{X}$ & & \\
\hline (EPS057) Verify the 1.0V Regulator is enabled after System Board digital command. & $\mathrm{X}$ & $\mathrm{X}$ & & $\mathrm{X}$ & & & $\mathrm{X}$ & & & & & \\
\hline (EPS058) Verify the 1.0V Regulator is disabled after System Board digital command. & $\mathrm{X}$ & $\mathrm{X}$ & & $\mathrm{X}$ & & & $\mathrm{X}$ & & & & & \\
\hline $\begin{array}{l}\text { (EPS059) Verify via telemetry the } 1.0 \mathrm{~V} \text { Regulator input and output power indicates the } \\
\text { proper levels. }\end{array}$ & & $\mathrm{X}$ & & $\mathrm{X}$ & & $\mathrm{X}$ & $\mathrm{X}$ & & $\mathrm{X}$ & $\mathrm{X}$ & & \\
\hline $\begin{array}{l}\text { (EPS060) Verify the 1.0V Regulator disables power after detecting a short circuit } \\
\text { condition. }\end{array}$ & $\mathrm{X}$ & & & & & & & & & & & \\
\hline $\begin{array}{l}\text { (EPS061) Verify the } 1.0 \mathrm{~V} \text { Regulator disables power after detecting an over-temperature } \\
\text { condition. }\end{array}$ & $\mathrm{X}$ & & & & & & & & & & & \\
\hline (EPS062) Verify the 1.0V Regulator enables power after the fault condition is cleared. & $\mathrm{X}$ & & & & & & & & & & & \\
\hline (EPS063) Verify the System Board supplies power to the 3.3V Payload Regulator. & & $\mathrm{X}$ & $\mathrm{X}$ & $\mathrm{X}$ & & $\mathrm{X}$ & $\mathrm{X}$ & & $\mathrm{X}$ & $\mathrm{X}$ & & \\
\hline $\begin{array}{l}\text { (EPS064) Verify the 3.3V Payload Regulator is enabled after System Board digital } \\
\text { command. }\end{array}$ & $X$ & $X$ & & $X$ & & & $X$ & & & & & \\
\hline $\begin{array}{l}\text { (EPS065) Verify the 3.3V Payload Regulator is disabled after System Board digital } \\
\text { command. }\end{array}$ & $X$ & $X$ & & $X$ & & & $X$ & & & & & \\
\hline $\begin{array}{l}\text { (EPS066) Verify via telemetry the } 3.3 \mathrm{~V} \text { Payload Regulator input and output power } \\
\text { indicates the proper levels. }\end{array}$ & & $X$ & & $X$ & & $X$ & $X$ & & $X$ & $X$ & & \\
\hline
\end{tabular}




\begin{tabular}{|c|c|c|c|c|c|c|c|c|c|c|c|c|}
\hline \multirow{2}{*}{ Power Regulator Test Requirement } & \multicolumn{12}{|c|}{ Phase } \\
\hline & 1 & 2 & 3 & 4 & 5 & 6 & 7 & 8 & 9 & 10 & 11 & 12 \\
\hline $\begin{array}{l}\text { (EPS067) Verify the } 3.3 \mathrm{~V} \text { Payload Regulator disables power after detecting a short } \\
\text { circuit condition. }\end{array}$ & $\mathrm{X}$ & & & & & & & & & & & \\
\hline $\begin{array}{l}\text { (EPS068) Verify the } 3.3 \mathrm{~V} \text { Payload Regulator disables power after detecting an over- } \\
\text { temperature condition. }\end{array}$ & $\mathrm{X}$ & & & & & & & & & & & \\
\hline $\begin{array}{l}\text { (EPS069) Verify the 3.3V Payload Regulator enables power after the fault condition is } \\
\text { cleared. }\end{array}$ & $\mathrm{X}$ & & & & & & & & & & & \\
\hline (EPS070) Verify the System Board supplies power to the 5.0V Payload Regulator. & & $\mathrm{X}$ & $\mathrm{X}$ & $\mathrm{X}$ & & $\mathrm{X}$ & $X$ & & $\mathrm{X}$ & $\mathrm{X}$ & & \\
\hline $\begin{array}{l}\text { (EPS071) Verify the 5.0V Payload Regulator is enabled after System Board digital } \\
\text { command. }\end{array}$ & $X$ & $\mathrm{X}$ & & $X$ & & & $X$ & & & & & \\
\hline $\begin{array}{l}\text { (EPS072) Verify the 5.0V Payload Regulator is disabled after System Board digital } \\
\text { command. }\end{array}$ & $X$ & $X$ & & $X$ & & & $X$ & & & & & \\
\hline $\begin{array}{l}\text { (EPS073) Verify via telemetry the } 5.0 \mathrm{~V} \text { Payload Regulator input and output power } \\
\text { indicates the proper levels. }\end{array}$ & & $X$ & & $X$ & & $X$ & $X$ & & $X$ & $X$ & & \\
\hline $\begin{array}{l}\text { (EPS074) Verify the 5.0V Payload Regulator disables power after detecting a short } \\
\text { circuit condition. }\end{array}$ & $X$ & & & & & & & & & & & \\
\hline $\begin{array}{l}\text { (EPS075) Verify the } 5.0 \mathrm{~V} \text { Payload Regulator disables power after detecting an over- } \\
\text { temperature condition. }\end{array}$ & $X$ & & & & & & & & & & & \\
\hline $\begin{array}{l}\text { (EPS076) Verify the 5.0V Payload Regulator enables power after the fault condition is } \\
\text { cleared. }\end{array}$ & $X$ & & & & & & & & & & & \\
\hline
\end{tabular}




\begin{tabular}{|c|c|c|c|c|c|c|c|c|c|c|c|c|}
\hline \multirow{2}{*}{ Power Regulator Test Requirement } & \multicolumn{12}{|c|}{ Phase } \\
\hline & 1 & 2 & 3 & 4 & 5 & 6 & 7 & 8 & 9 & 10 & 11 & 12 \\
\hline (EPS077) Verify the System Board supplies power to the 1.8 to 5.5V Regulator 1. & & $\mathrm{X}$ & $\mathrm{X}$ & $\mathrm{X}$ & & $X$ & $\mathrm{X}$ & & $\mathrm{X}$ & $\mathrm{X}$ & & \\
\hline $\begin{array}{l}\text { (EPS078) Verify the } 1.8 \text { to } 5.5 \mathrm{~V} \text { Regulator } 1 \text { is enabled after System Board digital } \\
\text { command. }\end{array}$ & $\mathrm{X}$ & $\mathrm{X}$ & & $\mathrm{X}$ & & & $\mathrm{X}$ & & & & & \\
\hline $\begin{array}{l}\text { (EPS079) Verify the } 1.8 \text { to } 5.5 \mathrm{~V} \text { Regulator } 1 \text { is disabled after System Board digital } \\
\text { command. }\end{array}$ & $\mathrm{X}$ & $\mathrm{X}$ & & $\mathrm{X}$ & & & $\mathrm{X}$ & & & & & \\
\hline $\begin{array}{l}\text { (EPS080) Verify via telemetry the } 1.8 \text { to } 5.5 \mathrm{~V} \text { Regulator } 1 \text { input and output power } \\
\text { indicates the proper levels. }\end{array}$ & & $\mathrm{X}$ & & $\mathrm{X}$ & & $\mathrm{X}$ & $\mathrm{X}$ & & $\mathrm{X}$ & $\mathrm{X}$ & & \\
\hline $\begin{array}{l}\text { (EPS081) Verify the } 1.8 \text { to } 5.5 \mathrm{~V} \text { Regulator } 1 \text { disables power after detecting a short } \\
\text { circuit condition. }\end{array}$ & $\mathrm{X}$ & & & & & & & & & & & \\
\hline $\begin{array}{l}\text { (EPS082) Verify the } 1.8 \text { to } 5.5 \mathrm{~V} \text { Regulator } 1 \text { disables power after detecting an over- } \\
\text { temperature condition. }\end{array}$ & $\mathrm{X}$ & & & & & & & & & & & \\
\hline $\begin{array}{l}\text { (EPS083) Verify the } 1.8 \text { to } 5.5 \mathrm{~V} \text { Regulator } 1 \text { enables power after the fault condition is } \\
\text { cleared. }\end{array}$ & $\mathrm{X}$ & & & & & & & & & & & \\
\hline (EPS084) Verify the System Board supplies power to the 1.8 to 5.5V Regulator 2. & & $\mathrm{X}$ & $\mathrm{X}$ & $\mathrm{X}$ & & $\mathrm{X}$ & $\mathrm{X}$ & & $\mathrm{X}$ & $\mathrm{X}$ & & \\
\hline $\begin{array}{l}\text { (EPS085) Verify the } 1.8 \text { to } 5.5 \mathrm{~V} \text { Regulator } 2 \text { is enabled after System Board digital } \\
\text { command. }\end{array}$ & $\mathrm{X}$ & $\mathrm{X}$ & & $\mathrm{X}$ & & & $\mathrm{X}$ & & & & & \\
\hline $\begin{array}{l}\text { (EPS086) Verify the } 1.8 \text { to } 5.5 \mathrm{~V} \text { Regulator } 2 \text { is disabled after System Board digital } \\
\text { command. }\end{array}$ & $\mathrm{X}$ & $\mathrm{X}$ & & $\mathrm{X}$ & & & $X$ & & & & & \\
\hline
\end{tabular}




\begin{tabular}{|c|c|c|c|c|c|c|c|c|c|c|c|c|}
\hline \multirow{2}{*}{ Power Regulator Test Requirement } & \multicolumn{12}{|c|}{ Phase } \\
\hline & 1 & 2 & 3 & 4 & 5 & 6 & 7 & 8 & 9 & 10 & 11 & 12 \\
\hline $\begin{array}{l}\text { (EPS087) Verify via telemetry the } 1.8 \text { to } 5.5 \mathrm{~V} \text { Regulator } 2 \text { input and output power } \\
\text { indicates the proper levels. }\end{array}$ & & $\mathrm{X}$ & & $\mathrm{X}$ & & $\mathrm{X}$ & $\mathrm{X}$ & & $\mathrm{X}$ & $\mathrm{X}$ & & \\
\hline $\begin{array}{l}\text { (EPS088) Verify the } 1.8 \text { to } 5.5 \mathrm{~V} \text { Regulator } 2 \text { disables power after detecting a short } \\
\text { circuit condition. }\end{array}$ & $\mathrm{X}$ & & & & & & & & & & & \\
\hline $\begin{array}{l}\text { (EPS089) Verify the } 1.8 \text { to } 5.5 \mathrm{~V} \text { Regulator } 2 \text { disables power after detecting an over- } \\
\text { temperature condition. }\end{array}$ & $\mathrm{X}$ & & & & & & & & & & & \\
\hline $\begin{array}{l}\text { (EPS090) Verify the } 1.8 \text { to } 5.5 \mathrm{~V} \text { Regulator } 2 \text { enables power after the fault condition is } \\
\text { cleared. }\end{array}$ & $\mathrm{X}$ & & & & & & & & & & & \\
\hline (EPS091) Verify the System Board supplies power to the Processor Regulator. & & $\mathrm{X}$ & $\mathrm{X}$ & $\mathrm{X}$ & & $\mathrm{X}$ & $\mathrm{X}$ & & $\mathrm{X}$ & $\mathrm{X}$ & & \\
\hline $\begin{array}{l}\text { (EPS092) Verify via telemetry the Processor Regulator input and output power } \\
\text { indicates the proper levels. }\end{array}$ & & $\mathrm{X}$ & & $\mathrm{X}$ & & $\mathrm{X}$ & $\mathrm{X}$ & & $\mathrm{X}$ & $\mathrm{X}$ & & \\
\hline $\begin{array}{l}\text { (EPS093) Verify the Processor Regulator initiates a system hard reboot after detecting } \\
\text { an over-temperature condition. }\end{array}$ & $\mathrm{X}$ & & & & & & & & & & & \\
\hline (EPS094) Verify the System Board supplies power to the Flash Memory Regulators. & & $\mathrm{X}$ & $\mathrm{X}$ & $\mathrm{X}$ & & $\mathrm{X}$ & $\mathrm{X}$ & & $\mathrm{X}$ & $\mathrm{X}$ & & \\
\hline $\begin{array}{l}\text { (EPS095) Verify via telemetry the Flash Memory Regulator input and output power } \\
\text { indicates the proper levels. }\end{array}$ & & $\mathrm{X}$ & & $\mathrm{X}$ & & $\mathrm{X}$ & $\mathrm{X}$ & & $\mathrm{X}$ & $\mathrm{X}$ & & \\
\hline $\begin{array}{l}\text { (EPS096) Verify the Flash Memory Regulator initiates a system hard reboot after } \\
\text { detecting an over-temperature condition. }\end{array}$ & $\mathrm{X}$ & & & & & & & & & & & \\
\hline
\end{tabular}




\begin{tabular}{|c|c|c|c|c|c|c|c|c|c|c|c|c|}
\hline \multirow{2}{*}{ Power Regulator Test Requirement } & \multicolumn{12}{|c|}{ Phase } \\
\hline & 1 & 2 & 3 & 4 & 5 & 6 & 7 & 8 & 9 & 10 & 11 & 12 \\
\hline (EPS097) Verify the System Board supplies power to the SDRAM Regulators. & & $\mathrm{X}$ & $\mathrm{X}$ & $\mathrm{X}$ & & $\mathrm{X}$ & $\mathrm{X}$ & & $\mathrm{X}$ & $\mathrm{X}$ & & \\
\hline $\begin{array}{l}\text { (EPS098) Verify via telemetry the SDRAM Regulator input and output power indicates } \\
\text { the proper levels. }\end{array}$ & & $\mathrm{X}$ & & $\mathrm{X}$ & & $\mathrm{X}$ & $\mathrm{X}$ & & $\mathrm{X}$ & $\mathrm{X}$ & & \\
\hline $\begin{array}{l}\text { (EPS099) Verify the SDRAM Regulator initiates a system hard reboot after detecting } \\
\text { an over-temperature condition. }\end{array}$ & $\mathrm{X}$ & & & & & & & & & & & \\
\hline (EPS100) Verify the System Board supplies power to the 3.3V Memory Regulators. & & $\mathrm{X}$ & $\mathrm{X}$ & $\mathrm{X}$ & & $\mathrm{X}$ & $\mathrm{X}$ & & $\mathrm{X}$ & $\mathrm{X}$ & & \\
\hline $\begin{array}{l}\text { (EPS101) Verify via telemetry the } 3.3 \mathrm{~V} \text { Memory Regulator input and output power } \\
\text { indicates the proper levels. }\end{array}$ & & $\mathrm{X}$ & & $\mathrm{X}$ & & $\mathrm{X}$ & $\mathrm{X}$ & & $\mathrm{X}$ & $\mathrm{X}$ & & \\
\hline $\begin{array}{l}\text { (EPS102) Verify the } 3.3 \mathrm{~V} \text { Memory Regulator initiates a system hard reboot after } \\
\text { detecting an over-temperature condition. }\end{array}$ & $\mathrm{X}$ & & & & & & & & & & & \\
\hline
\end{tabular}

\subsubsection{Solar Array Panel Test Requirements}




\begin{tabular}{|c|c|c|c|c|c|c|c|c|c|c|c|c|}
\hline \multirow{2}{*}{ Solar Array Panel Test Requirement } & \multicolumn{12}{|c|}{ Phase } \\
\hline & 1 & 2 & 3 & 4 & 5 & 6 & 7 & 8 & 9 & 10 & 11 & 12 \\
\hline $\begin{array}{l}\text { (EPS103) Verify via telemetry the }- \text { Y Solar Panel responds to light and properly } \\
\text { supplies power to the System Board. }\end{array}$ & $\mathrm{X}$ & $\mathrm{X}$ & & $\mathrm{X}$ & & & $\mathrm{X}$ & & & & & \\
\hline $\begin{array}{l}\text { (EPS104) Verify via telemetry the }+ \text { Y Solar Panel responds to light and properly } \\
\text { supplies power to the System Board. }\end{array}$ & $\mathrm{X}$ & $\mathrm{X}$ & & $\mathrm{X}$ & & & $\mathrm{X}$ & & & & & \\
\hline $\begin{array}{l}\text { (EPS105) Verify via telemetry the }-\mathrm{X} \text { Solar Panel responds to light and properly } \\
\text { supplies power to the System Board. }\end{array}$ & $\mathrm{X}$ & $\mathrm{X}$ & & $\mathrm{X}$ & & & $\mathrm{X}$ & & & & & \\
\hline $\begin{array}{l}\text { (EPS106) Verify via telemetry the }+X \text { Solar Panel responds to light and properly } \\
\text { supplies power to the System Board. }\end{array}$ & $\mathrm{X}$ & $\mathrm{X}$ & & $\mathrm{X}$ & & & $\mathrm{X}$ & & & & & \\
\hline $\begin{array}{l}\text { (EPS107) Verify via telemetry the }-Z \text { Solar Panel responds to light and properly } \\
\text { supplies power to the System Board. }\end{array}$ & $\mathrm{X}$ & $\mathrm{X}$ & & $\mathrm{X}$ & & & $\mathrm{X}$ & & & & & \\
\hline $\begin{array}{l}\text { (EPS108) Verify via telemetry the }+Z \text { Solar Panel responds to light and properly } \\
\text { supplies power to the System Board. }\end{array}$ & $\mathrm{X}$ & $\mathrm{X}$ & & $\mathrm{X}$ & & & $\mathrm{X}$ & & & & & \\
\hline
\end{tabular}




\subsection{Payload Subsystem Test Requirements}

Each pico-satellite Payload is unique in its mission, function and requirements. Many Payloads are emerging technologies and prototypes designed to demonstrate theories or space applicability. Therefore, specific requirements are dependent on the Payload architecture and capabilities. However, each Payload must receive and perform specific functions to interfaces with defined components which are documented in this section.

Table A7 lists the Payload Subsystem capabilities being tested.

\begin{tabular}{|l|l|l|}
\hline \multicolumn{2}{|c|}{ Table A7: Payload Subsystem Test Summary } \\
\hline Section & Section Title & Capability Being Tested \\
\hline 8.5 .1 & Payload & Verify power is supplied \\
& & Verify signal transmission \\
& & Verify state entrance \\
\hline
\end{tabular}




\subsubsection{Payload Test Requirements}

\begin{tabular}{|c|c|c|c|c|c|c|c|c|c|c|c|c|}
\hline \multirow{2}{*}{ Payload Test Requirement } & \multicolumn{12}{|c|}{ Phase } \\
\hline & 1 & 2 & 3 & 4 & 5 & 6 & 7 & 8 & 9 & 10 & 11 & 12 \\
\hline (PSS001) Verify the System Board supplies power to the Payload. & & $\mathrm{X}$ & $\mathrm{X}$ & $\mathrm{X}$ & & $\mathrm{X}$ & $\mathrm{X}$ & & $\mathrm{X}$ & $\mathrm{X}$ & & \\
\hline (PSS002) Verify via telemetry the System Board capability to enable Payload power. & & $\mathrm{X}$ & & $\mathrm{X}$ & & $X$ & $X$ & & $X$ & $X$ & & \\
\hline $\begin{array}{l}\text { (PSS003) Verify via telemetry the System Board capability to disable the Payload } \\
\text { power. }\end{array}$ & & $X$ & & $X$ & & $X$ & $X$ & & $X$ & $X$ & & \\
\hline $\begin{array}{l}\text { (PSS004) Verify the Payload standby state is initiated via digital command from the } \\
\text { System Board. }\end{array}$ & & $X$ & & $X$ & & $X$ & $X$ & & $X$ & $X$ & & \\
\hline $\begin{array}{l}\text { (PSS005) Verify the Payload nominal state is initiated via digital command from the } \\
\text { System Board. }\end{array}$ & & $X$ & & $X$ & & $X$ & $X$ & & $X$ & $X$ & & \\
\hline $\begin{array}{l}\text { (PSS006) Verify the Payload provides telemetry after System Board digital sample } \\
\text { command or initiation. }\end{array}$ & & $X$ & $X$ & $X$ & & $X$ & $X$ & & $X$ & $X$ & & \\
\hline
\end{tabular}




\subsection{Propulsion Subsystem Test Requirements}

Based on the current pico-satellite requirements as defined in the CRD and CDS, pyrotechnic capabilities are not permitted. Therefore, the pico-satellite will not have fuel, oxidizer, tanks, plumbing, or thrusters to test. There are no propulsion subsystem test requirements. 


\subsection{Structural \& Thermal Subsystem Test Requirements}

The Structural \& Thermal Subsystem consists of the structural components, mechanisms, monitoring sensors, and thermal energy isolation and/or transfer devices. Pico-satellite SV's are assumed to be constantly tumbling during the orbit. Therefore, there is no active thermal control system with the assumption one side is never continually pointing at the sun or deep space. However, there are temperature sensors for critical components. Once the temperature sensor breaches a designated limit, the component is turned off until the temperature returns to within its limits.

Structural testing includes shock, random and sinusoidal vibration and structural qualification testing. These are typically verified in the acoustic test phase. For these tests, LSP-REQ-317.01 provides the requirements. However, if a different launch provider is used, their environmental requirements document should be substituted.

Pico-satellite architectures vary drastically between manufacturer and satellite generation as do their mission. As such, the quantity of deployable mechanisms ranges from a simple antenna to full solar array systems or sensor suites. Therefore, the deployment requirements have been placed in this section instead of their associated subsystem.

Table A8 lists the Structural \& Thermal Subsystem capabilities being tested. 


\begin{tabular}{|l|l|l|}
\hline \multicolumn{2}{|c|}{ Table A8: Structures \& Thermal Subsystem Test Summary } \\
\hline Section & Section Title & Capability Being Tested \\
\hline 8.7 .1 & Structural & $\begin{array}{l}\text { Structural loading in the three primary axes. } \\
\text { Deployment and proper alignment of } \\
\text { mechanisms. }\end{array}$ \\
\hline 8.7 .2 & Thermal Control & $\begin{array}{l}\text { Thermal Vacuum environmental testing } \\
\text { Verify power is supplied } \\
\text { Verify signal transmission }\end{array}$ \\
\hline
\end{tabular}




\subsubsection{Structural Test Requirements}

\begin{tabular}{|c|c|c|c|c|c|c|c|c|c|c|c|c|}
\hline \multirow{2}{*}{ Structural Test Requirement } & \multicolumn{12}{|c|}{ Phase } \\
\hline & 1 & 2 & 3 & 4 & 5 & 6 & 7 & 8 & 9 & 10 & 11 & 12 \\
\hline $\begin{array}{l}\text { (STR001) Verify the SV withstands without degradation of system capabilities the } \\
\text { structural environmental conditions specified in Table } 2 \text { of LSP-REQ-317.01. }\end{array}$ & & & & & $\mathrm{X}$ & & & & & & & \\
\hline $\begin{array}{l}\text { (STR002) Verify the SV withstands without degradation of system capabilities the } \\
\text { structural environmental conditions specified in Table } 1 \text { of LSP-REQ-317.01. }\end{array}$ & & & & & $\mathrm{X}$ & & & & & & & \\
\hline (STR003) Verify the launch ready single SV does not exceed $1.33 \mathrm{~kg}$ mass. & & & & & & & $\mathrm{X}$ & & & & & \\
\hline (STR004) Verify the launch ready triple SV does not exceed $4.0 \mathrm{~kg}$ mass. & & & & & & & $\mathrm{X}$ & & & & & \\
\hline $\begin{array}{l}\text { (STR005) Verify the launch ready SV center of gravity is located within a sphere of } 2 \\
\mathrm{~cm} \text { from its geometric center. }\end{array}$ & & & & & & & $\mathrm{X}$ & & & & & \\
\hline $\begin{array}{l}\text { (STR006) Verify the separation springs provide the minimum initial and final end force } \\
\text { of } 0.5 \mathrm{lbs} \text {. and } 1.5 \mathrm{lbs} \text {. respectively, as defined in Table } 1 \text { of the CDS. }\end{array}$ & $\mathrm{X}$ & & & & & & & & & & & \\
\hline $\begin{array}{l}\text { (STR007) Verify the separation springs provide the minimum throw length } 0.05 \text { inches } \\
\text { above the standoff surface, as defined in Table } 1 \text { of the CDS. }\end{array}$ & $\mathrm{X}$ & & & & & & & & & & & \\
\hline $\begin{array}{l}\text { (STR008) Verify the structural rails do not have a surface roughness greater than } 1.6 \\
\mu \text { m, as defined in the CDS. }\end{array}$ & $\mathrm{X}$ & & & & & & & & & & & \\
\hline $\begin{array}{l}\text { (STR009) Verify all mechanisms deploy a minimum of } 30 \text { minutes after the } \\
\text { deployment switch is activated from the PPOD ejection. }\end{array}$ & & $\mathrm{X}$ & & $\mathrm{X}$ & & & & $\mathrm{X}$ & & & & \\
\hline
\end{tabular}




\begin{tabular}{|c|c|c|c|c|c|c|c|c|c|c|c|c|}
\hline \multirow{2}{*}{ Structural Test Requirement } & \multicolumn{12}{|c|}{ Phase } \\
\hline & 1 & 2 & 3 & 4 & 5 & 6 & 7 & 8 & 9 & 10 & 11 & 12 \\
\hline $\begin{array}{l}\text { (STR010) Verify all deployable mechanism deploy from the stowed position and lock } \\
\text { into the operational position. }\end{array}$ & & $\mathrm{X}$ & & $\mathrm{X}$ & & & & $\mathrm{X}$ & & & & \\
\hline
\end{tabular}

\subsubsection{Thermal Control Subsystem Test Requirements}

\begin{tabular}{|c|c|c|c|c|c|c|c|c|c|c|c|c|}
\hline \multirow{2}{*}{ Thermal Control Subsystem Test Requirement } & \multicolumn{12}{|c|}{ Phase } \\
\hline & 1 & 2 & 3 & 4 & 5 & 6 & 7 & 8 & 9 & 10 & 11 & 12 \\
\hline $\begin{array}{l}\text { (TCS001) Verify the SV withstands without degradation of system capabilities the } \\
\text { TVAC environmental conditions specified in Table } 1 \text { of LSP-REQ-317.01. }\end{array}$ & & & & & & $\mathrm{X}$ & & & & & & \\
\hline $\begin{array}{l}\text { (TCS002) Verify the System Board supplies power to the -Y Side Panel Temperature } \\
\text { Sensor. }\end{array}$ & & $\mathrm{X}$ & $\mathrm{X}$ & $\mathrm{X}$ & & $\mathrm{X}$ & $\mathrm{X}$ & & & & & \\
\hline $\begin{array}{l}\text { (TCS003) Verify the System Board supplies power to the }+ \text { Y Side Panel Temperature } \\
\text { Sensor. }\end{array}$ & & $\mathrm{X}$ & $X$ & $\mathrm{X}$ & & $\mathrm{X}$ & $\mathrm{X}$ & & & & & \\
\hline $\begin{array}{l}\text { (TCS004) Verify the System Board supplies power to the }-X \text { Side Panel Temperature } \\
\text { Sensor. }\end{array}$ & & $\mathrm{X}$ & $X$ & $\mathrm{X}$ & & $\mathrm{X}$ & $X$ & & & & & \\
\hline $\begin{array}{l}\text { (TCS005) Verify the System Board supplies power to the }+X \text { Side Panel Temperature } \\
\text { Sensor. }\end{array}$ & & $X$ & $X$ & $X$ & & $X$ & $X$ & & & & & \\
\hline
\end{tabular}




\begin{tabular}{|c|c|c|c|c|c|c|c|c|c|c|c|c|}
\hline \multirow{2}{*}{ Thermal Control Subsystem Test Requirement } & \multicolumn{12}{|c|}{ Phase } \\
\hline & 1 & 2 & 3 & 4 & 5 & 6 & 7 & 8 & 9 & 10 & 11 & 12 \\
\hline $\begin{array}{l}\text { (TCS006) Verify the System Board supplies power to the }-Z \text { Side Panel Temperature } \\
\text { Sensor. }\end{array}$ & & $\mathrm{X}$ & $\mathrm{X}$ & $\mathrm{X}$ & & $\mathrm{X}$ & $\mathrm{X}$ & & & & & \\
\hline $\begin{array}{l}\text { (TCS007) Verify the System Board supplies power to the }+Z \text { Side Panel Temperature } \\
\text { Sensor. }\end{array}$ & & $\mathrm{X}$ & $\mathrm{X}$ & $\mathrm{X}$ & & $\mathrm{X}$ & $\mathrm{X}$ & & & & & \\
\hline $\begin{array}{l}\text { (TCS008) Verify the System Board supplies power to the Comm Subsystem } \\
\text { Temperature Sensor. }\end{array}$ & & $\mathrm{X}$ & $\mathrm{X}$ & $\mathrm{X}$ & & $\mathrm{X}$ & $\mathrm{X}$ & & & & & \\
\hline $\begin{array}{l}\text { (TCS009) Verify the System Board supplies power to the System Board Temperature } \\
\text { Sensor. }\end{array}$ & & $\mathrm{X}$ & $\mathrm{X}$ & $\mathrm{X}$ & & $X$ & $\mathrm{X}$ & & & & & \\
\hline $\begin{array}{l}\text { (TCS010) Verify the -Y Side Panel Temperature Sensor indicate the proper telemetry } \\
\text { values when power is applied. }\end{array}$ & & $\mathrm{X}$ & $\mathrm{X}$ & $\mathrm{X}$ & & $\mathrm{X}$ & $\mathrm{X}$ & & & & & \\
\hline $\begin{array}{l}\text { (TCS011) Verify the }+ \text { Y Side Panel Temperature Sensor indicate the proper telemetry } \\
\text { values when power is applied. }\end{array}$ & & $\mathrm{X}$ & $\mathrm{X}$ & $\mathrm{X}$ & & $\mathrm{X}$ & $\mathrm{X}$ & & & & & \\
\hline $\begin{array}{l}\text { (TCS012) Verify the }-X \text { Side Panel Temperature Sensor indicate the proper telemetry } \\
\text { values when power is applied. }\end{array}$ & & $X$ & $X$ & $X$ & & $X$ & $X$ & & & & & \\
\hline $\begin{array}{l}\text { (TCS013) Verify the }+X \text { Side Panel Temperature Sensor indicate the proper telemetry } \\
\text { values when power is applied. }\end{array}$ & & $X$ & $X$ & $X$ & & $X$ & $X$ & & & & & \\
\hline $\begin{array}{l}\text { (TCS014) Verify the }-Z \text { Side Panel Temperature Sensor indicate the proper telemetry } \\
\text { values when power is applied. }\end{array}$ & & $X$ & $X$ & $X$ & & $X$ & $X$ & & & & & \\
\hline
\end{tabular}




\begin{tabular}{|c|c|c|c|c|c|c|c|c|c|c|c|c|}
\hline \multirow{2}{*}{ Thermal Control Subsystem Test Requirement } & \multicolumn{12}{|c|}{ Phase } \\
\hline & 1 & 2 & 3 & 4 & 5 & 6 & 7 & 8 & 9 & 10 & 11 & 12 \\
\hline $\begin{array}{l}\text { (TCS015) Verify the }+Z \text { Side Panel Temperature Sensor indicate the proper telemetry } \\
\text { values when power is applied. }\end{array}$ & & $\mathrm{X}$ & $\mathrm{X}$ & $\mathrm{X}$ & & $\mathrm{X}$ & $X$ & & & & & \\
\hline $\begin{array}{l}\text { (TCS016) Verify the Comm Subsystem Temperature Sensor indicate the proper } \\
\text { telemetry values when power is applied. }\end{array}$ & & $\mathrm{X}$ & $\mathrm{X}$ & $\mathrm{X}$ & & $\mathrm{X}$ & $X$ & & & & & \\
\hline $\begin{array}{l}\text { (TCS017) Verify the System Board Temperature Sensor indicate the proper telemetry } \\
\text { values when power is applied. }\end{array}$ & & $\mathrm{X}$ & $\mathrm{X}$ & $X$ & & $\mathrm{X}$ & $\mathrm{X}$ & & & & & \\
\hline $\begin{array}{l}\text { (TCS018) Verify the -Y Side Panel Temperature Sensor transmits telemetry upon } \\
\text { System Board digital command. }\end{array}$ & & $\mathrm{X}$ & $\mathrm{X}$ & $\mathrm{X}$ & & $\mathrm{X}$ & $\mathrm{X}$ & & & & & \\
\hline $\begin{array}{l}\text { (TCS019) Verify the }+ \text { Y Side Panel Temperature Sensor transmits telemetry upon } \\
\text { System Board digital command. }\end{array}$ & & $\mathrm{X}$ & $\mathrm{X}$ & $\mathrm{X}$ & & $\mathrm{X}$ & $\mathrm{X}$ & & & & & \\
\hline $\begin{array}{l}\text { (TCS020) Verify the }-X \text { Side Panel Temperature Sensor transmits telemetry upon } \\
\text { System Board digital command. }\end{array}$ & & $\mathrm{X}$ & $\mathrm{X}$ & $\mathrm{X}$ & & $\mathrm{X}$ & $\mathrm{X}$ & & & & & \\
\hline $\begin{array}{l}\text { (TCS021) Verify the }+X \text { Side Panel Temperature Sensor transmits telemetry upon } \\
\text { System Board digital command. }\end{array}$ & & $X$ & $X$ & $X$ & & $X$ & $X$ & & & & & \\
\hline $\begin{array}{l}\text { (TCS022) Verify the }-Z \text { Side Panel Temperature Sensor transmits telemetry upon } \\
\text { System Board digital command. }\end{array}$ & & $X$ & $X$ & $X$ & & $X$ & $X$ & & & & & \\
\hline $\begin{array}{l}\text { (TCS023) Verify the }+Z \text { Side Panel Temperature Sensor transmits telemetry upon } \\
\text { System Board digital command. }\end{array}$ & & $X$ & $X$ & $X$ & & $X$ & $X$ & & & & & \\
\hline
\end{tabular}




\begin{tabular}{|l|l|l|l|l|l|l|l|l|l|l|l|l|l|}
\hline \multicolumn{1}{|c|}{ Thermal Control Subsystem Test Requirement } & \multicolumn{5}{|c|}{ Phase } \\
\cline { 2 - 9 } & & $\mathbf{1}$ & $\mathbf{2}$ & $\mathbf{3}$ & $\mathbf{4}$ & $\mathbf{5}$ & $\mathbf{6}$ & $\mathbf{7}$ & $\mathbf{8}$ & $\mathbf{9}$ & $\mathbf{1 0}$ & $\mathbf{1 1}$ & $\mathbf{1 2}$ \\
\hline $\begin{array}{l}\text { (TCS024) Verify the Comm Subsystem Temperature Sensor transmits telemetry upon } \\
\text { System Board digital command. }\end{array}$ & & $X$ & $X$ & $X$ & & $X$ & $X$ & & & \\
\hline $\begin{array}{l}\text { (TCS025) Verify the System Board Temperature Sensor transmits telemetry upon } \\
\text { System Board digital command. }\end{array}$ & & $X$ & $X$ & $X$ & & $X$ & $X$ & \\
\hline
\end{tabular}




\section{Requirement Verification Documentation}

After performing and successfully verifying all system test requirements in the appropriate test phases the evidence must be compiled for record. The test report evidence should include all documentation used to perform test, REQIDs verified, any recorded data, test discrepancies or failures with their dispositions, test configuration drawings, and any other pertinent information which could be used to communicate the test program and test requirement verification process. 